\title{
TOMATE (Lycopersicum esculentum Mill) ORGÂNICO: O CONTEÚDO NUTRICIONAL E A OPINIÃO DO CONSUMIDOR
}

\author{
RENATA GALHARDO BORGUINI
}

\begin{abstract}
Dissertação apresentada à Escola Superior de Agricultura "Luiz de Queiroz", Universidade de São Paulo, para obtenção do título de Mestre em Agronomia, Área de Concentração: Ciência e Tecnologia de Alimentos.
\end{abstract}

P I R A C I C A B A

Estado de São Paulo - Brasil

Novembro - 2002 


\title{
TOMATE (Lycopersicum esculentum Mill) ORGÂNICO: O CONTEÚDO NUTRICIONAL E A OPINIÃO DO CONSUMIDOR
}

\section{RENATA GALHARDO BORGUINI}

Engenheiro Agrônomo

Orientadora: Profa. Dra. MARINA VIEIRA DA SILVA

\begin{abstract}
Dissertação apresentada à Escola Superior de Agricultura "Luiz de Queiroz", Universidade de São Paulo, para obtenção do título de Mestre em Agronomia, Área de Concentração: Ciência e Tecnologia de Alimentos.
\end{abstract}

P I R A C I C A B A

Estado de São Paulo - Brasil

Novembro -2002 


\title{
Dados Internacionais de Catalogação na Publicação (CIP) DIVISÃO DE BIBLIOTECA E DOCUMENTAÇÃO - ESALQ/USP
}

\author{
Borguini, Renata Galhardo \\ Tomate (Lycopersic um esc ulentum Mill) orgânico : o conteúdo \\ nutric ional e a opinião do consumidor/ Renata Galhardo Borguini. - - \\ Piracicaba, 2002. \\ $110 \mathrm{p}$. \\ Dissertação (mestrado) - - Escola Superior de Agricultura Luiz de \\ Queiroz, 2002. \\ Bibliografia. \\ 1. Alimento orgânico 2. Consumidor 3. Consumo de a limentos 4. \\ Mercado agríc ola 5. Segura nça alimentar 6. Tomate 7. Va lor nutritivo I. \\ Título
}

CDD 641.35642

"Permitida a cópia total ou parcial deste documento, desde que citada a fonte - $\mathrm{O}$ autor" 
À sociedade brasileira, por todos os anos de formação em Universidade Pública. OFEREÇO

Aos meus queridos pais Carlos e Teresa e à minha querida irmã Milena. DEDICO 


\section{AGRADECIMENTOS}

À Deus que conduz minha vida com infinita bondade e amor;

À Escola Superior de Agricultura “Luiz de Queiroz” pela formação profissional;

Ao Departamento de Agroindústria, Alimentos e Nutrição por toda a estrutura e assistência necessárias à realização desse trabalho;

À profa. Dra. Marina Vieira da Silva pela orientação, apoio e estímulo durante todos os momentos desta importante etapa da minha vida;

A CAPES pelo apoio financeiro;

À profa. Dra. Marta Helena Fillet Spoto por toda a cooperação;

À profa. Dra. Marília Oetterer pelas contribuições ao trabalho;

Ao prof. Dr. Rodolfo Hoffman pela atenção dispensada na análise dos resultados;

Ao prof. Dr. Jaime Amaya-Farfan pelas contribuições ao trabalho; 
Aos funcionários, funcionárias do Departamento de Agroindústria, Alimentos e Nutrição. Meu agradecimento especial à Ivani e Juliana pelas grandes contribuições durante as análises;

Às bibliotecárias da Esalq, pela orientação com relação à bibliografia. Meu agradecimento especial à Bia por todas as orientações e à Ligiana pela revisão da dissertação;

À Ana Cláudia pelo grande disposição e auxílio durante a realização das análises;

À Mari pela grande amizade, agradável convívio e paciência em todos os momentos;

À Giovana pela ensinamentos de inglês e pela grande amizade;

Ao grande amigo Fábio pelo seu companheirismo e otimismo;

À minha grande e maravilhosa família pelo carinho e dedicação;

Aos queridos amigos e professores da graduação que foram muito importantes para minha formação profissional e pessoal;

Aos colegas do curso, especialmente à Lucimeire pelas contribuições durante as análises;

À todos que ajudaram de alguma forma meus sinceros agradecimentos. 


\section{SUMÁRIO}

Página

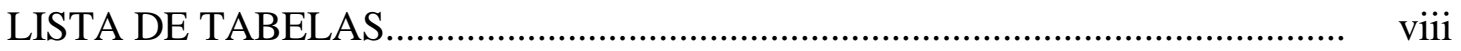

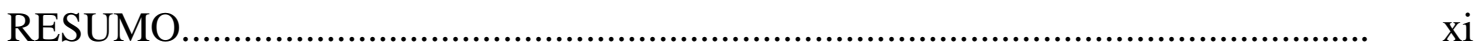

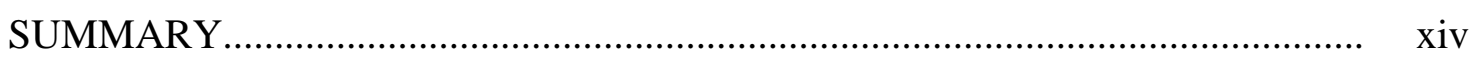

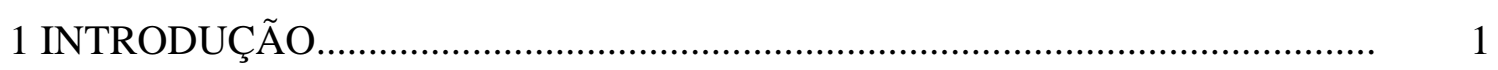

2 REVISÃO DE LITERATURA................................................................ 4

2.1 Segurança Alimentar............................................................................... 4

2.2 Agricultura Orgânica.............................................................................. 5

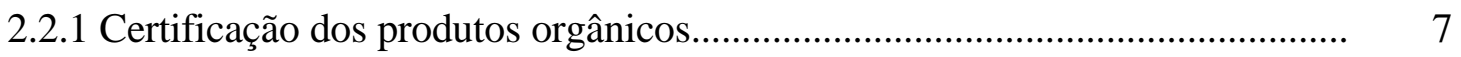

2.2.2 Mercado de produtos orgânicos.................................................................. 9

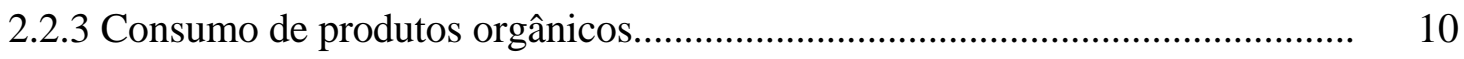

2.3 Qualidade de pós-colheita de frutas e hortaliças................................................ 16

2.3.1 Valor nutricional dos alimentos orgânicos....................................................... 18

2.3.2 Qualidade organoléptica dos alimentos orgânicos.......................................... 22

2.3.3 Teor de nitrato em alimentos orgânicos........................................................... 23

2.4 Resíduos de agroquímicos em alimentos........................................................ 27

2.5 Alimento Orgânico: o caso do tomate............................................................... 28

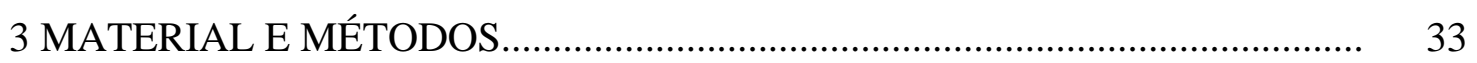

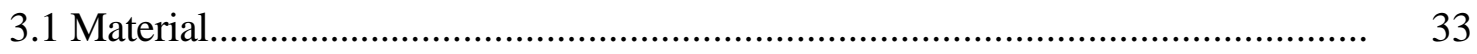

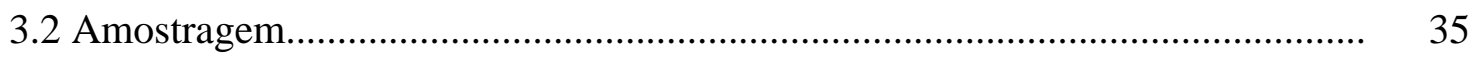

3.3 Caracterização dos tomates....................................................................... 35

3.3.1 Análises físico-químicas......................................................................... $\quad 35$ 
3.3.2 Análise Sensorial................................................................................. 38

3.4 População do estudo................................................................................... 40

3.5 Análise estatística........................................................................................... 41

4 RESULTADOS E DISCUSSÃO.................................................................. 42

4.1 Análises físicas...................................................................................... 42

4.2 Análises físico-químicas............................................................................... 46

4.3 Análise Sensorial................................................................................ 54

4.4 Caracterização dos participantes da pesquisa: aspectos socioeconômicos, estilo de vida e atitudes relativas à aquisição e consumo de alimentos.............. 57

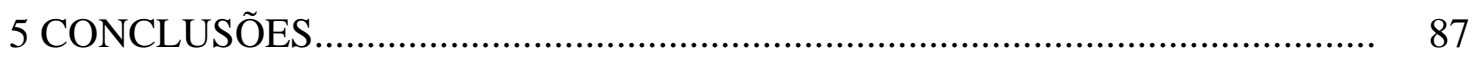

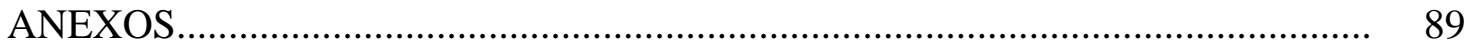

REFERÊNCIAS BIBLIOGRÁFICAS.............................................................. 102 


\section{LISTA DE TABELAS}

Página

1 Datas de plantio e de colheita dos tomates dos cultivares Carmem

e Débora, produzidos por meio de cultivo orgânico e convencional..................... 34

2 Características físicas dos cultivares de tomate in natura produzidos pelo cultivo orgânico e pelo cultivo convencional.

3 Características químicas, vitamina $\mathrm{C}$, licopeno, $\beta$-caroteno, $\mathrm{pH}$, acidez total titulável e do teor de sólidos solúveis, dos cultivares de tomate in natura produzidos pelo cultivo orgânico e convencional.

4 Características químicas, umidade (expressa em percentagem) e minerais $(\mathrm{mg} / 100 \mathrm{~g})$, dos cultivares de tomate in natura produzidos pelo cultivo orgânico $\quad$ e convencional............................................

5 Médias das notas conferidas pelos provadores aos atributos avaliados (aroma, sabor, cor e aspecto geral) dos frutos de tomate in natura dos cultivares Carmem e Débora produzidos pelo método de cultivo convencional e orgânico.

6 Comparação das médias das notas atribuídas pelos provadores aos quatro tratamentos

7 Distribuição dos entrevistados de acordo com o gênero. Piracicaba, 2002......... 58

8 Distribuição dos entrevistados de acordo com o nível de escolaridade. Piracicaba, 2002

9 Distribuição dos entrevistados de acordo com o estrato de renda mensal familiar (em salários mínimos). Piracicaba, 2002 
10 Distribuição dos entrevistados de acordo com o número de pessoas que integram a família. Piracicaba, 2002.

11 Distribuição dos entrevistados de acordo com o tempo de incorporação de novos hábitos alimentares ao estilo de vida. Piracicaba, 2002.

12 Distribuição dos entrevistados de acordo com as citações referentes à adoção de práticas alimentares "alternativas". Piracicaba, 2002.

13 Distribuição dos entrevistados de acordo com as citações referentes aos atributos são considerados durante a compra de tomate.

Piracicaba, 2002

14 Distribuição dos entrevistados de acordo com a frequiência de consumo de tomate. Piracicaba, 2002..

15 Distribuição das citações registradas pelos entrevistados, relativas a fonte de informação que motivou o aumento de consumo de tomate. Piracicaba, 2002.

16 Distribuição dos entrevistados, de acordo com estratos de renda familiar (em salários mínimos) e freqüência de consumo de tomate. Piracicaba, 2002.

17 Distribuição dos entrevistados, de acordo com o nível de escolaridade e frequiência de consumo de tomate. Piracicaba, 2002

18 Distribuição dos entrevistados, de acordo com o costume de comprar e consumir alimentos orgânicos. Piracicaba, 2002

19 Distribuição dos entrevistados, de acordo com a frequiência de consumo de alimentos orgânicos. Piracicaba, 2002.

20 Distribuição das citações referentes aos tipos de alimentos orgânicos adquiridos e consumidos pelos entrevistados. Piracicaba, 2002

21 Distribuição das citações registradas pelos entrevistados, relativas aos tipos de alimentos orgânicos consumidos.

Piracicaba, 2002.

22 Distribuição das citações dos entrevistados, referentes aos locais de compra dos alimentos orgânicos. Piracicaba, 2002. 
23 Distribuição dos entrevistados de acordo com os estratos de renda mensal familiar (em salários mínimos) e a freqüência de consumo de alimentos orgânicos. Piracicaba, 2002.

24 Distribuição das citações relativas ao conceito de alimentos orgânicos, registrados pelos entrevistados. Piracicaba, 2002

25 Distribuição das citações dos entrevistados, de acordo com as fontes consultadas para a conceituação de alimentos orgânicos. Piracicaba, 2002.

26 Distribuição das citações dos entrevistados de acordo com as motivações para comprar e consumir alimentos orgânicos. Piracicaba, 2002..

27 Distribuição das citações dos entrevistados de acordo com as motivações para não comprar e não consumir alimentos orgânicos. Piracicaba, 2002..

28 Distribuição dos entrevistados, de acordo com o costume de comprar e consumir tomate orgânico. Piracicaba, 2002

29 Distribuição dos entrevistados, de acordo com a freqüência de consumo de tomate orgânico. Piracicaba, 2002.

30 Distribuição dos entrevistados de acordo com a disposição para pagar, com acréscimo, o preço do tomate orgânico (em relação ao valor pago pelo tomate convencional).

Piracicaba, 2002

31 Distribuição dos entrevistados, de acordo com os estratos de renda familiar (em salários mínimos) e os acréscimos (percentuais) no preço do tomate orgânico que os mesmos estão dispostos a pagar Piracicaba, 2002 


\title{
TOMATE (Lycopersicum esculentum Mill) ORGÂNICO: O CONTEÚDO NUTRICIONAL E A OPINIÃO DO CONSUMIDOR
}

\author{
Autora: RENATA GALHARDO BORGUINI \\ Orientadora: Profa. Dra. MARINA VIEIRA DA SILVA
}

\section{RESUMO}

A pesquisa visa descrever o conteúdo nutricional e as características sensoriais do tomate orgânico em comparação ao convencional, bem como conhecer o perfil, a opinião e as atitudes dos consumidores com relação aos alimentos orgânicos. Foram analisadas as características físico-químicas e sensoriais dos tomates dos cultivares Carmem e Débora produzidos por meio do cultivo orgânico e convencional. As amostras de tomate foram avaliadas fisicamente, considerando-se a textura e cor, e quimicamente o $\mathrm{pH}$, sólidos solúveis totais, acidez total titulável, ácido ascórbico, teores de licopeno, $\beta$-caroteno e de minerais. As amostras de tomate foram também avaliadas sensorialmente quanto ao aroma, sabor, cor e aspecto geral. Visando preencher a lacuna de informações sobre o comportamento do consumidor, no tocante aos alimentos orgânicos, realizou-se uma pesquisa envolvendo amostra, contendo indivíduos pertencentes à comunidade universitária, entre outros. Os resultados revelaram que os frutos do cultivar Débora convencional apresentaram tonalidade maior da cor vermelha, quando comparados aos frutos Débora orgânico, enquanto o tomate Carmem orgânico apresentou tonalidade maior de vermelho do que o Carmem convencional. Analisando- 
se os valores, de acordo com o método de cultivo, pode-se observar quanto à textura, que os resultados foram, praticamente iguais entre o lote orgânico $(8,85)$ e convencional $(8,47)$ do cultivar Carmem. Para o cultivar Débora foram observados valores de 10,28 e 9,38 para o cultivo orgânico e convencional, respectivamente. Verificou-se que o tomate Carmem produzido organicamente apresentou um teor de vitamina $\mathrm{C}$ mais elevado quando comparado com o obtido pela produção convencional. Para o cultivar Débora foi identificado um teor de vitamina $\mathrm{C}$, mais elevado, nas amostras de frutos produzidos convencionalmente. Os teores de licopeno identificados nas amostras do cultivar Carmem foram de 2,9 e 2,5 mg/100g nos frutos produzidos pelo cultivo orgânico e convencional, respectivamente. Observou-se uma discreta diferença entre os teores de licopeno obtidos nos frutos do cultivar Débora cultivados organicamente $(3,5 \mathrm{mg} / 100 \mathrm{~g})$ e convencionalmente $(3,7 \mathrm{mg} / 100 \mathrm{~g})$. Com relação aos teores dos minerais, destaca-se o enxofre que se revelou superior para os frutos produzidos organicamente e o cobre que apresentou conteúdo muito elevado nos frutos produzidos convencionalmente $(0,33 \mathrm{mg}$ e 0,26mg), quando comparado com os valores obtidos nos frutos cultivados organicamente $(0,07 \mathrm{mg}$ e $0,05 \mathrm{mg})$. Por meio da análise sensorial dos frutos, constatouse que apenas para os atributos de sabor e aspecto geral houve diferença significativa ao nível de $5 \%$, entre os tratamentos. Considerando a opinião do consumidor, preocupações com a saúde foram as principais motivações para a compra de alimentos orgânicos. O fato de serem identificados como livres de pesticidas foi considerada, pelos consumidores, como uma característica importante. Com relação às restrições, registradas pelos consumidores, ao consumo de alimentos orgânicos, merece destaque as citações relativas aos preços elevados e a disponibilidade limitada. 


\title{
ORGANIC TOMATO (Lycopersicum Esculentum Mill): NUTRIENT CONTENT AND CONSUMER'S OPINION
}

\author{
Author: RENATA GALHARDO BORGUINI \\ Adviser: Profa. Dra. MARINA VIEIRA DA SILVA
}

\section{SUMMARY}

This survey seeks to describe the nutritional content and the sensorial characteristics of organic tomato in comparison to the conventional tomato, and assesses the current consumer's opinion on organic foods. The physical, chemical and sensorial characteristics of the tomatoes Carmem and Débora cultivate produced through the organic and conventional cultivation were determined. Samples of tomatoes underwent physical analyses of texture and color, and chemical analyses of $\mathrm{pH}$, total soluble solids, titratable acidity, ascorbic acid, licopene, $\beta$-carotene and minerals. Samples also were sensorally evaluated for aroma, flavor, color and general aspect. With the purpose of filling gap of information on consumer behavior about organic foods, a survey was conduced among individual that included members of the university community. The results showed that Débora cultivate conventionally grown exhibited larger tonality of red than Débora organically grown, while the Carmem organic tomato presented larger tonality of red than Carmem conventional. With the analysis of the texture values in agreement with the cultivation method, it can be observed that the texture presented very similar values between the organic lot $(8,85)$ and conventional lot $(8,47)$ of Carmem 
cultivate. Débora cultivate exhibited values of 10,28 and 9,38, these values were observed for the organic and conventional cultivation, respectively. It was verified that the tomato Carmem organically grown presented a higher content of vitamin $\mathrm{C}$ in comparison to the conventional production. Débora cultivate exhibited greater content of vitamin $\mathrm{C}$ in the samples of conventionally produced tomatoes. The licopene content exhibit for Carmem cultivate were of 2,9 and $2,5 \mathrm{mg} / 100 \mathrm{~g}$ in tomatoes produced by the organic and conventional cultivation, respectively. A small difference was observed between the licopene content presented in Débora organically $(3,5 \mathrm{mg} / 100 \mathrm{~g})$ and conventionally $(3,7 \mathrm{mg} / 100 \mathrm{~g})$ produced tomato. In relation to the mineral contents, the sulfur turned out to be superior in organically produced tomatoes and the copper turned out to be higher for the conventionally produced fruits $(0,33 \mathrm{mg}$ and $0,26 \mathrm{mg})$ in comparison to the values obtained in organically grown tomatoes $(0,07 \mathrm{mg}$ and $0,05 \mathrm{mg})$. Through the sensorial analysis of the fruits, it was verified that just for the flavor and general aspect had significant difference at the level of 5\%, among the treatments. Considering the consumer's opinion, concerns about the health were the main reason for purchasing for organic foods, and the fact of they be considered free from pesticides an important characteristic of those products. In relation to the restrictions to the consumption of organic foods, the most important factors are the high prices and the limited availability. 


\section{INTRODUÇÃO}

A segurança alimentar tem crescido em importância, juntamente com os novos processos de industrialização e com as recentes tendências de comportamento do consumidor, especialmente na sua vertente que enfatiza os aspectos qualitativos (food safety). Assim, pode-se definir food safety como a garantia do consumidor em adquirir alimentos com atributos de qualidade que sejam do seu interesse, entre os quais destacam-se os atributos ligados à saúde. A escassez de dados relativos às questões envolvendo qualidade dos alimentos no Brasil e a percepção dos consumidores com relação a atributos de qualidade tem dificultado o desenvolvimento de estudos mais detalhados na área de food safety. No entanto, reconhece-se que o interesse e a importância do assunto são crescentes (Spers \& Kassouf, 1996a), e constituem-se em argumentos que justificam a intensificação de pesquisas na área.

Têm sido observados fatos que evidenciam uma mudança de hábito alimentar entre os brasileiros, na direção de uma maior demanda de produtos orgânicos. A julgar pela presença desses produtos nas gôndolas das grandes redes de supermercados, estimase que exista um potencial de mercado expressivo para esses produtos. Tais observações, por si mesmas, chamam a atenção para a importância desse novo nicho de consumo e para a necessidade da implementação de pesquisas sobre o tema (Borguini \& Mattos, 2002).

Orgânico é um termo de rotulagem que indica que os produtos são produzidos com conciliação às normas da produção orgânica, e que foram certificados por uma estrutura ou autoridade de certificação devidamente constituída. A agricultura orgânica se baseia no emprego mínimo de insumos externos. Devido à contaminação ambiental, 
as práticas de agricultura orgânica não podem garantir a ausência total de resíduos. No entanto, é possível aplicar métodos destinados a reduzir ao mínimo a contaminação do ar, do solo e da água. Os manipuladores, elaboradores e vendedores aderem às normas que mantém a integridade dos produtos da agricultura orgânica. A meta principal da agricultura orgânica é obter um nível ótimo de saúde e produtividade das comunidades interdependentes de organismos do solo, plantas, animais e seres humanos (FAO/OMS, 1999).

Há um mercado potencial para os produtos orgânicos, uma vez que existe o desconforto manifestado por uma parcela da população, em continuar adquirindo e consumindo alguns alimentos produzidos de forma convencional, como exemplos o tomate, morango e batata, cujo cultivo reconhecidamente envolve o emprego de substanciais quantidades de agroquímicos (Penteado, 2000).

De acordo com alguns autores, existe uma crença de que o sabor do alimento produzido organicamente é mais agradável e que seu valor nutricional é superior quando comparado com o alimento produzido convencionalmente (Paschoal, 1994 e Lampkin, 1990). No entanto, há necessidade de realização de maior número de pesquisas científicas com vistas à comprovação de tais vantagens do alimento produzido organicamente, em relação ao cultivo convencional.

É interessante supor que os consumidores durante sua permanência nos locais de comercialização devem escolher, por exemplo, entre dois tipos de batata ou pêra. Uma é identificada como orgânica e a outra como produzida convencionalmente. Cada uma das referidas frutas apresenta tamanho similar e aparenta ser da mesma variedade. Diante da dificuldade da escolha, é evidente que a grande maioria dos consumidores gostaria de ser esclarecida quanto às diferenças qualitativas entre produtos de preços invariavelmente tão distintos. Entretanto, respostas objetivas em relação à segurança e conteúdo de nutrientes não são freqüentemente disponibilizadas. 
Tendo em vista a lacuna de informações sobre vários aspectos dos alimentos orgânicos, entre eles os nutricionais e sensoriais e ainda, limitadas análises referentes às atitudes dos consumidores, quanto aos referidos alimentos, julgou-se pertinente a realização da presente pesquisa, tendo como objetivos:

- determinar o conteúdo de vitamina C, licopeno, â-caroteno e minerais, os teores de umidade, sólidos solúveis, acidez total titulável, $\mathrm{pH}$, assim como, avaliar a cor e a textura do tomate orgânico e convencional;

- conhecer a opinião dos consumidores sobre alimentos orgânicos. 


\section{REVISÃO DE LITERATURA}

\subsection{Segurança Alimentar}

De acordo com Spers \& Kassouf (1996b), o risco da ocorrência de doenças associadas ao consumo de alimentos contendo aditivos, pesticidas, hormônios, toxinas naturais ou ainda outros tipos de substâncias, tem contribuído para gerar insegurança e despertar um vasto rol de preocupações do consumidor. Segundo os referidos autores, a cada dia intensificam-se as exigências do consumidor para adquirir alimentos isentos de riscos, ou seja, um alimento seguro. Os autores registram que, quando se trata de alimentos, o consumidor, principalmente nos países desenvolvidos, invariavelmente é irredutível quanto à qualidade do produto que irá comprar.

A segurança alimentar com ênfase nos aspectos qualitativos pode ainda ser entendida como a aquisição pelo consumidor de alimento de boa qualidade, livres de contaminantes de natureza química (pesticidas), biológica (organismos patogênicos), física (vidros, pedras), ou qualquer substância que possa acarretar problemas à saúde (Spers \& Kassouf, 1996b).

Segundo Spers \& Kassouf (1996a), quando se enfatiza o conceito de segurança do ponto de vista qualitativo, inclui-se também a referência a uma alimentação saudável, rica em vegetais e frutas. Note-se que, ao considerar duas pessoas que não fumam e que não bebam excessivamente, o fator de maior influência no aumento da expectativa de vida é o conteúdo da dieta. 
Devido ao seu caráter multidisciplinar e a complexidade de fatores que o influenciam, o conceito de segurança alimentar deve ser adotado em todo o sistema agroalimentar, ou seja, as práticas inerentes à segurança devem ser incorporadas em todas as fases desde a produção até o consumidor final, envolvendo, obviamente, a indústria, processos de distribuição e comercialização.

\subsection{Agricultura Orgânica}

A agricultura orgânica se desenvolveu a partir dos trabalhos de compostagem e adubação orgânica realizados por Howard na Índia, entre o período de 1925 e 1930 e divulgados por Lady Balfour na Inglaterra e Rodale nos Estados Unidos. No Brasil, o

movimento expandiu-se a partir da criação, em 1989, da Associação de Agricultura Orgânica (Ehlers, 1996).

De acordo com Penteado (2000), a agricultura orgânica para alcançar seus objetivos dispensa o uso de adubos e defensivos químicos sintéticos que possam causar desequilíbrios ecológicos ou que sejam agressivos ao organismo humano e ao meio ambiente. É um sistema que adota normas para produzir um alimento mantendo suas características originais e que atenda as expectativas do consumidor.

A agricultura orgânica pode ser definida como sendo um método de cultivo que visa o estabelecimento de sistemas agrícolas ecologicamente equilibrados e estáveis, economicamente produtivos, de elevada eficiência quanto à utilização dos recursos naturais de produção e socialmente bem estruturados, que resultem em alimentos saudáveis e livres de resíduos tóxicos, e em outros produtos agrícolas de qualidade superior, produzidos em harmonia com a natureza e com vistas ao atendimento das reais necessidades da população (Paschoal, 1994).

O sistema orgânico de produção pressupõe uma preocupação deliberada com a procura de harmonia entre o meio ambiente e a produção agrícola. Neste sentido, assume-se que o sistema agrícola em questão ou o agroecossistema, cause o menor impacto possível ao meio ambiente. No entanto, há, também, o reconhecimento de que é 
impossível ter impacto nulo. No sistema orgânico são também considerados os parâmetros que visam reduzir ao mínimo o impacto ambiental sem comprometer a eficiência da meta produtiva. $O$ processo de produção da agricultura orgânica tem como orientação normativa a produção de alimentos em um sistema que seja ambientalmente equilibrado, economicamente viável e socialmente justo (Ehlers, 1996). Trata-se, portanto, de um investimento do qual se espera, ao mesmo tempo, a conservação dos recursos naturais, garantindo a sustentabilidade do solo, da água, da biodiversidade e a melhoraria do nível de produtividade, com o favorecimento da distribuição de renda e oferecimento de produtos com qualidade, para os consumidores (Paschoal, 1994).

De acordo com Food Agriculture Organization - FAO e World Health Organization - WHO (1999), a agricultura orgânica integra uma vasta gama de metodologias que apoiam a proteção do meio ambiente. Os sistemas de produção orgânica se baseiam em normas de produção específicas e precisas, cuja finalidade é obter ecossistemas ótimos, que sejam sustentáveis, contemplando os aspectos sociais, ecológicos e econômicos. Na intenção de descrever mais claramente o sistema orgânico são adotados também termos como "biológico" e "ecológico". Os requisitos para a produção dos alimentos orgânicos diferem dos estabelecidos para outros produtos agrícolas, especialmente pelo fato dos procedimentos de produção integrarem a forma de identificação e a rotulagem de tais produtos, assim como o registro das declarações das propriedades atribuídas aos mesmos.

Considera-se produto da agricultura orgânica, seja in natura ou processado, todo aquele obtido em sistema orgânico de produção agropecuária e industrial. $\mathrm{O}$ conceito de sistema orgânico de produção agropecuária e industrial abrange os sistemas denominados ecológico, biodinâmico, natural, sustentável, regenerativo, biológico, agroecológico e permacultura. São identificados como produtor orgânico, tanto o produtor de matérias-primas como o processador das mesmas (Penteado, 2000).

A fim de regulamentar as atividades desenvolvidas no setor, o Ministério da Agricultura, Pecuária e Abastecimento (MAPA) estabeleceu, pela Instrução Normativa 007/99, de 17 de maio de 1999, as normas disciplinares para produção, tipificação, processamento, envase, distribuição, identificação e certificação da qualidade de 
produtos orgânicos, sejam eles de origem animal ou vegetal. Os procedimentos constantes da referida instrução são concordantes com aqueles praticados na maioria dos países da Europa, nos Estados Unidos e no Japão (Ormond et al., 2002).

Segundo Ormond et al. (2002), a produção de hortaliças e legumes é parte importante da produção sob manejo orgânico, mas os referidos produtos ocupam áreas relativamente pequenas em comparação com o volume obtido. A produção de cereais, oleaginosas, frutas e o café, por exemplo, tendem a ocupar áreas maiores, porém é a pecuária de corte ou leite que se apresenta como sendo aquela que demanda grandes áreas. O fato da produção de hortaliças orgânicas no Brasil envolver substancial número de produtores, decorre da adequação do sistema de produção orgânica às características de pequenas propriedades, envolvendo freqüentemente a gestão familiar.

Nesta pesquisa serão adotadas as expressões agricultura orgânica e produtos orgânicos para a referência, de forma simplificada, ao processo e aos produtos procedentes de áreas manejadas segundo os princípios mencionados.

\subsubsection{Certificação dos produtos orgânicos}

Nos países europeus, na América do Norte, na Austrália e também no Brasil, entre outros países, visando disciplinar o importante segmento econômico, que envolve os alimentos orgânicos, em plena expansão (tanto nos países desenvolvidos como em muitos países em desenvolvimento), associações de agricultura orgânica estabeleceram normas técnicas para a produção, a industrialização e o comércio de alimentos orgânicos e de insumos naturais (Paschoal, 1994).

De acordo com Spers \& Chaddad (1997), autoridades sanitárias, de países desenvolvidos, entre os quais, alguns integrantes da União Européia, Estados Unidos e Canadá, têm atentado para uma mudança nos hábitos alimentares, que privilegia o maior consumo de produtos orgânicos. Mais recentemente, os referidos países chegaram a adotar medidas de estímulo a esse tipo de produção agrícola. Na Europa, por exemplo, ganha força a política de criação de selos ou certificados que diferenciem os alimentos 
apresentados à população como saudáveis, ambientalmente corretos, frente aos alimentos convencionais.

Os países da Comunidade Européia e o Japão, por exemplo, exigem que os produtos orgânicos importados sejam certificados por entidades reconhecidas pelos órgãos dos países de origem e também pela Internacional Federation of Organic Agriculture Movementes (IFOAM). Essa entidade tem por atribuição avaliar, normatizar e divulgar os padrões de comercialização em âmbito internacional de produtos orgânicos, congregando também a maioria das instituições de agricultura orgânica e entidades certificadoras do mundo, envolvendo mais de 600 membros, com atuação em 95 países (Penteado, 2000).

De acordo com Peña (1996), no estado de São Paulo a Associação de Agricultura Orgânica (AAO) localizada na cidade de São Paulo e o Instituto Biodinâmico (IBD) situado no município de Botucatu, são as mais tradicionais entidades certificadoras do Brasil. Atuam, também, no estado de São Paulo, a Associação de Agricultura Natural, a Fundação Mokiti Okada (FMO) e a Associação de Produtores de Alimentos Naturais (APAN). Cada entidade fornece certificados orgânicos, com pequenas variações nos critérios adotados, porém unânimes na exigência de respeito às normas básicas da agricultura orgânica. Segundo Ormond et al. (2002), atuam no Brasil 19 certificadoras, das quais 12 nacionais e sete estrangeiras.

Para a produção orgânica vegetal ou animal, há uma série de normas técnicas exigidas para a obtenção do selo verde ou selo orgânico. A certificação é um processo que atesta a condição de um determinado alimento, ou seja, se é realmente orgânico. O processo possibilita o reconhecimento do alimento como tendo sido obtido por meio de atividades que atenderam às normas estabelecidas para a produção orgânica. Para o mercado interno, as embalagens ou produtos deverão incluir o selo orgânico, enquanto que para o mercado externo deve ser emitido um certificado para cada tipo de modalidade de exportação adotada pelos agentes (Penteado, 2000).

De acordo com Paschoal (1994), os selos oficiais de Certificação ou de Garantia têm as seguintes finalidades: fomentar as práticas de agricultura orgânica; estabelecer e promover uma marca de qualidade, para possibilitar aos consumidores uma forma de 
aquisição de produtos orgânicos; proteger os consumidores contra fraudes comerciais e proteger, da ação de agentes desonestos, os agricultores, criadores, industriais e comerciantes de alimentos orgânicos e insumos.

\subsubsection{Mercado de produtos orgânicos}

A venda de alimentos orgânicos nos Estados Unidos vem revelando aumento de $20 \%$ a cada ano. A procura de alimentos orgânicos é também expressiva nos países europeus, devido à conscientização da população sobre os riscos, para a saúde, decorrentes da presença de resíduos químicos nos alimentos (Penteado, 2000).

A adesão das grandes lojas de vendas de alimentos na distribuição de produtos orgânicos e suas campanhas publicitárias na mídia, estabelecendo elos entre o consumo desses alimentos e a saúde, também foram de grande importância para o crescimento do consumo e, conseqüentemente, da produção orgânica na Europa. Ainda assim, cerca de $60 \%$ dos produtos orgânicos são comercializados em lojas especializadas, $20 \%$ nos supermercados e os $20 \%$ restantes em feiras, em locais alternativos ou por meio de entregas domiciliares, entre outras (Ormond et al., 2002).

A abertura do mercado brasileiro para produtos orgânicos é recente. Apoiado pela mídia e com a elevada aceitação pela população a demanda vem revelando crescimento, desde 1990, de cerca de $10 \%$ a $20 \%$ ao ano. Há uma expansão da oferta, antes restrita às feiras de produtos orgânicos, com o efetivo envolvimento das grandes redes varejistas, como por exemplo, o Grupo Pão de Açúcar e o Carrefour, entre outros. O surgimento de associações, cooperativas e empresas distribuidoras de produtos orgânicos, vem permitindo maior oferta desse tipo de alimento, na maioria das cidades do país (Penteado, 2000).

Embora a produção tenha aumentado vigorosamente, o mercado revelou maior velocidade de crescimento, contribuindo para que a atividade deixasse de pertencer a um nicho artesanal e mantida praticamente com o envolvimento dos produtores movidos por motivações ideológicas e entrasse no mercado de produtos alimentícios, dominado por grandes redes, que comercializam quantidades expressivas de produtos. $\mathrm{O}$ volume anual 
do mercado brasileiro de agricultura orgânica, livre de defensivos e adubos químicos sintéticos, situa-se na faixa de US\$220 milhões a US\$ 300 milhões. O Brasil aderiu a esse tipo de produção comercialmente no início dos anos 80 e possui atualmente uma área estimada de 100 mil hectares. Em termos globais, estima-se que o mercado mundial tenha atingido vendas que se aproximam de US\$ 25 bilhões em 2001, com área cultivada superior a 10 milhões de hectares (Ormond et al., 2002).

As análises elaboradas por Ormond et al. (2002) sugerem que o crescimento reflete a grande demanda internacional pelo produto. As exportações representam uma parcela importante do faturamento total deste segmento, sendo que diversos produtos vêm sendo destinados ao mercado externo, como é o caso da soja, café, açúcar, castanha-de-caju, suco concentrado de laranja, óleo de palma, entre outros. Os principais importadores desse tipo de produto brasileiro são os Estados Unidos, a Europa e o Japão. O crescimento anual do consumo de produtos orgânicos nos referidos países aproximase de $20 \%$.

\subsubsection{Consumo de produtos orgânicos}

Há tempo, tem sido adotada estratégia, visando promover uma imagem junto aos consumidores, da produção orgânica, como sendo aquela que adota recursos para produzir um alimento que é, ao mesmo tempo, melhor e mais saudável quando comparado com aqueles produzidos com adoção do sistema da agricultura convencional (Lampkin, 1990).

O consumidor tem revelado maior interesse para o conteúdo nutricional do alimento do que para os atributos de conveniência ou facilidades decorrentes do processamento e estocagem. Além disso, também tem dedicado maior atenção aos aspectos negativos, potencialmente presentes nos alimentos, como por exemplo os resíduos de pesticidas, presença de aditivos e gorduras em excesso nos alimentos e teor de nitrato, do que para fatores como presença de proteínas, vitaminas e elementos minerais. No entanto, vale lembrar que o uso de quantidades excessivas de fertilizantes minerais afeta a composição nutricional dos alimentos (Lampkin, 1990). 
De acordo com Borguini \& Mattos (2002), diversos trabalhos têm sido realizados nos últimos anos com o intuito de analisar a demanda por alimentos orgânicos. A grande maioria desses estudos tem priorizado a análise do comportamento dos mercados europeu e norte-americano. Em geral, procura-se determinar os principais fatores que influenciam a decisão de compra de alimentos orgânicos, assim como traçar um perfil dos consumidores desses produtos.

Glaser \& Thompson (1998) avaliaram, durante o período de setembro de 1990 a dezembro de 1996, a demanda por alimentos orgânicos nos supermercados dos EUA, concentrado-se na análise de quatro tipos de produtos: brócolis, feijão verde, ervilha e milho. Os autores observaram que, apesar do forte crescimento das vendas de orgânicos no período em questão, a participação desses produtos no total das vendas registradas nos supermercados ainda era pequena. Além disso, constataram que o preço dos orgânicos era bastante, superior quando comparado com os alimentos convencionais.

Um ponto importante a ser analisado, de acordo com Lohr (2000) é a relevância da variável preço na decisão de compra de alimentos orgânicos. Segundo pesquisa realizada em 1998 nos EUA, 33\% dos consumidores que não adquiriam orgânicos afirmavam ser o preço uma barreira à compra dos produtos. Em 2000, com a continuidade da pesquisa, foi verificado que havia ocorrido um crescimento de $16 \%$, ou seja, $49 \%$ dos consumidores americanos continuavam alegando que o preço ainda era considerado um fator decisivo para não adquirirem o produto. Além disso, os próprios comerciantes reconhecem que o preço mais elevado dos alimentos orgânicos constitui uma dificuldade para a ampliação do volume de vendas. Embora consumidores rotineiros apresentassem preocupação relativamente menor com o preço dos alimentos orgânicos, esta variável continua sendo um fator decisivo para a motivação e efetivação da compra.

Com relação às restrições ao consumo de alimentos orgânicos, Wier \& Andersen (2001) destacaram os preços elevados, disponibilidade limitada e, em menor grau, falta de confiança na certificação e na qualidade dos produtos. Os autores, também traçaram o perfil de um consumidor típico de alimentos orgânicos, conforme sugerido pelos trabalhos analisados, mostrando que, na maior parte dos casos há predomínio do grupo 
de mulheres jovens, pertencentes a famílias pouco numerosas e com bom nível de escolaridade. Os autores não conseguiram avaliar a real influência exercida pelas variáveis renda, nível de urbanização do local da moradia e estado civil, sobre o comportamento do consumidor. Entretanto, deve-se destacar que existem algumas variações no tocante ao impacto dessas variáveis, entre as diversas análises, consideradas na pesquisa implementada pelos referidos autores.

Lohr (2000) analisou os motivos que levam os consumidores de diversos países a adquirir alimentos orgânicos. O autor concluiu que na Europa e nos EUA, o sabor, a qualidade e a busca por um alimento "fresco" são fatores citados como sendo as principais motivações para o consumo de orgânicos. Além disso, existe, entre os consumidores, uma percepção generalizada a respeito dos benefícios à saúde proporcionados pelo consumo desses produtos. No Japão, a segurança alimentar é o principal motivo, alegado pela população, para o consumo de orgânicos, seguido pelos atributos referentes à qualidade nutricional e ao sabor.

Resultados de pesquisas relativos ao comportamento do consumidor de dimentos orgânicos na Europa, EUA e Japão permitem concluir que a preocupação com a saúde é a principal motivação para o consumo, embora, com menor frequiência, preocupações ambientais e com a qualidade também sejam lembradas. No tocante ao preço mais elevado dos alimentos orgânicos, em relação aos convencionais, muitos indivíduos concordam em investir parte de seus recursos financeiros para a obtenção de um resultado positivo, ou seja, de um produto considerado de melhor qualidade e seguro. Por outro lado, também existem diversos consumidores que apontam o preço como um empecilho para intensificação da demanda por alimentos orgânicos, assim como a oferta relativamente reduzida e a falta de informações adequadas sobre os produtos (Borguini \& Mattos, 2002).

Pesquisa realizada, em 1996, pelo Instituto Gallup, envolvendo amostra da população da cidade de São Paulo, revelou tendência de aumento do consumo de verduras e legumes orgânicos, quando os consumidores tiverem acesso a maior volume de informações sobre os produtos cultivados com a adoção dos referidos métodos (Souza, 2000). De acordo com os dados levantados pelo referido Instituto, os 
consumidores entrevistados revelaram disposição para pagar um preço, com acréscimo de até $30 \%$, por alimentos considerados mais saudáveis. Além disso, se esses produtos forem comercializados em supermercados, atraem a preferência de mais de $70 \%$ das consumidoras que detém maior poder aquisitivo. No entanto é enfatizado que a aparência do alimento deve ser boa e ainda, serem obrigatoriamente acompanhadas de certificação.

Pesquisa realizada na cidade de São Paulo, por Cerveira \& Castro (1999), revelou que a maioria dos consumidores, ao serem questionados sobre os fatores que motivaram a decisão pela compra de produtos orgânicos em detrimento aos demais - ou seja, os convencionais - fez referência ao item saúde pessoal e familiar, como sendo o de maior importância. Chamou, também, a atenção dos autores, os dados relativos aos motivos que determinaram as opções dos consumidores, que revelaram estar reorientando o seu consumo, privilegiando os produtos orgânicos. Entre as motivações, a referência à preocupação com a preservação do meio ambiente, ocupa o quinto lugar entre as citações, enquanto a atenção com a saúde, assumiu a primeira posição, entre as principais motivações citadas. Os entrevistados foram questionados quanto ao valor (percentual) adicional ao preço "tradicional", que estavam dispostos a pagar para ter acesso a um produto de melhor qualidade. Os autores observaram que, aproximadamente, um terço dos entrevistados afirmaram que se dispunham a pagar um preço, com acréscimo de $30 \%$, em relação ao produto convencional.

Ainda de acordo com os referidos autores, mais da metade dos consumidores citou que o produto orgânico não contém agrotóxico. Esta é uma reação provavelmente decorrente do impacto das informações veiculadas pela maioria dos meios de comunicação, que ressaltam essa característica do produto orgânico. Outras citações como produto natural $(15 \%)$ e saudáveis $(12 \%)$ sucederam a resposta registrada pela maioria dos indivíduos. Entretanto, verifica-se que poucos consumidores (apenas 2\%) revelaram conhecer as técnicas envolvidas no processo de produção do alimento orgânico. Um dado ainda mais inusitado foi obtido entre um número reduzido de integrantes da amostra, que afirmou que a produção em questão, não é agressiva ao meio ambiente. Portanto, o principal motivo da opção desses consumidores por produtos 
orgânicos é realmente a qualidade dos mesmos, especialmente no que se refere à possibilidade de ver atendida a expectativa que os mesmos têm a capacidade de proteger a saúde. Os entrevistados declararam que os orgânicos são produtos sem contaminação por agrotóxicos, sendo portanto, considerados "mais naturais" e saudáveis. De modo geral, consideraram que a comercialização do produto e suas características "são boas", mas reclamaram da falta de um maior número de locais de comercialização. Esses consumidores concordavam que pagariam um preço mais elevado por esses produtos quando comparada à disposição para o pagamento de produtos convencionais. Na verdade, estão dispostos a despender mais recursos para poderem manter esses produtos em sua pauta alimentar. Finalmente, chama atenção a preocupação desses consumidores limitada, quase que praticamente, ao seu interesse com a própria saúde e a de sua família, não demonstrando interesse maior com os benefícios ambientais que podem ser assegurados pela adoção da agricultura orgânica (Cerveira \& Castro, 1999).

Em pesquisa realizada por Assis et al. (1995) no estado do Rio de Janeiro, foi observado que a maioria dos entrevistados considerava indispensável a disponibilidade de alimentos orgânicos, mostrando disposição em pagar um preço mais elevado em relação ao produto convencional. Foi possível constatar que a diferenciação observada no hábito alimentar dos consumidores de produtos orgânicos, decorre, predominantemente em função da diferenciação, percebida pelo consumidor, do próprio alimento orgânico em relação ao alimento convencional, sendo a saúde pessoal e da família o principal fator de indução ao consumo. Esse resultado é confirmado ao se observar que, em relação ao grau de entendimento dos entrevistados sobre o que é um alimento orgânico, $60 \%$ associaram sua resposta ao não-uso de agrotóxicos, $29 \%$ à qualidade do alimento, e também $29 \%$ registraram que o alimento é produzido somente com a utilização de insumos naturais (não-sintetizados). Por outro lado, somente $18 \%$ relacionaram a resposta aos aspectos associados ao solo e $9 \%$ à utilização de recursos da natureza, aspectos envolvidos na questão ambiental. Portanto, a saúde pessoal e da família foram as principais motivações para que os consumidores adotem um padrão de alimentação tendo por base produtos da agricultura orgânica, identificados basicamente como produtos "sem agrotóxicos". 
Pode-se observar que, apesar da disposição para pagar mais caro por um produto que não polui o meio ambiente, as pesquisas realizadas no Rio de Janeiro (1992) e São Paulo (1998) não identificaram esse aspecto como uma motivação decisiva para o consumo de orgânicos. Uma possível interpretação para esse resultado é que os produtores e vendedores de alimentos orgânicos, na divulgação de seus produtos, ainda não exploram adequadamente os fatores que justificam o maior preço.

De acordo com Borguini \& Mattos (2002), um aspecto interessante a ser considerado quando se analisam os dados obtidos junto aos consumidores brasileiros é justamente o fato dos resultados obtidos serem muito similares, mesmo quando se considera que os levantamentos foram realizados em épocas e locais distintos. Uma interpretação possível para o fato é que os produtores e vendedores de alimentos orgânicos não têm explorado adequadamente o potencial de consumo desse tipo de produto no mercado nacional. Os especialistas e os profissionais da mídia têm papel importante, devido à possibilidade de serem reconhecidos como formadores de opinião e, portanto, capacitados para influenciar e estimular potenciais consumidores em direção a um maior consumo do alimento orgânico. Tal argumento tem por base resultados de pesquisas que oferecem indícios do impacto que campanhas publicitárias, enfatizando questões ambientais, poderiam causar, ao promover o consumo de alimentos orgânicos. Entretanto, vale lembrar que iniciativas nesse sentido não são freqüentemente observadas no mercado brasileiro.

No Brasil, segundo pesquisa divulgada pelo Banco Nacional de Desenvolvimento Econômico e Social (BNDES), cerca de metade dos alimentos orgânicos, cujos preços foram monitorados apresentaram preços superiores (mais de $100 \%$ ) em relação aos seus similares produzidos de forma convencional. Em diversos países europeus, essa diferença não ultrapassa $50 \%$. Registra-se ainda que em alguns casos o diferencial não alcança 20\% (Ormond et al., 2002).

De acordo com Khatounian (1994), a divulgação de resultados de pesquisas, associando problemas de saúde humana e alterações ambientais, decorrentes do impacto da agricultura convencional, tem motivado, em todo o mundo, o crescimento da demanda por produtos orgânicos. Esses produtos, invariavelmente, alcançam preços 
mais elevados que seus congêneres convencionais, pois aos alimentos orgânicos são atribuídas características que os caracterizam como superiores.

O conjunto de evidências parece apontar uma tendência de crescimento substancial do consumo, em todo o mundo, para os alimentos considerados saudáveis. Cada vez mais são estabelecidas e reafirmadas as associações do binômio alimento e saúde, com o estabelecimento de uma relação do tipo causa efeito. De acordo com Viglio (1996), possivelmente exista uma tendência de classificação, pela população, dos alimentos como sendo "bons" aqueles identificados como saudáveis e "maus", os demais, que potencialmente podem causar prejuízos para a saúde.

\subsection{Qualidade pós-colheita de frutas e hortaliças}

A qualidade pós-colheita dos frutos relaciona-se com o conjunto de atributos ou propriedades que, entre outros, os tornam apreciáveis como alimento. De modo abrangente, a qualidade pode ser definida como o conjunto de inúmeras características que diferenciam componentes individuais de um mesmo produto e que têm influência na determinação do grau de aceitação pelo comprador. Dessa forma, devem ser considerados os atributos físicos, sensoriais e a composição química, bem como devem ser realizadas associações ou relações entre as medidas objetivas e subjetivas, para um melhor entendimento das transformações que ocorrem, e que afetem ou não a qualidade do produto (Chitarra, 1994).

De acordo com Lampkin (1990), a qualidade dos alimentos não pode ser definida, exclusivamente, tendo por base uma característica individual mensurável. Usualmente avalia-se a qualidade adotando-se três critérios, considerados principais: aparência (tamanho, forma, cor, isenção de injúrias e um sabor especialmente associado

com o produto individual); conveniência tecnológica (atributos específicos que determinam a conveniência do gênero alimentício para processamento e estocagem); valor nutricional (conteúdo de nutrientes essenciais para os seres humanos como é o caso de proteínas e vitaminas, e ausência de substâncias prejudiciais como nitratos, toxinas naturais, resíduos de pesticidas e metais pesados). 
Portanto, os atributos de qualidade dos produtos dizem respeito à sua aparência, sabor, odor, textura, valor nutritivo e segurança. Esses atributos têm importância variada, de acordo com os interesses de cada segmento da cadeia de comercialização, ou seja, do produtor até o consumidor. Segundo Chitarra (1994), o valor nutritivo, por não afetar a aparência e também a qualidade organoléptica, é o atributo de qualidade menos considerado na cadeia de comercialização de frutos pelos produtores e consumidores.

Os componentes mais abundantes em frutos são a umidade e os carboidratos. No entanto, do ponto de vista nutricional, devem ser considerados além das vitaminas e os minerais, as fontes energéticas como os açúcares solúveis e polissacarídeos (o amido em alguns frutos). Outros polissacarídeos (celuloses, hemicelulose e lignina) têm importância, por constituírem as fibras dietárias. De acordo com Chitarra (1994), os frutos, de forma geral, não podem ser considerados como fontes de lipídeos ou de proteínas.

Os dados sobre a composição química de frutos são bastante variáveis, em decorrência dos numerosos condicionantes, tais como: as diferenças entre cultivares, grau de maturidade do produto, estação de colheita, local e clima. Substanciais perdas de nutrientes, especialmente de vitamina $\mathrm{C}$, podem ocorrer devido ao armazenamento inadequado ou por longos períodos, contribuindo também para a variação na composição do fruto (Chitarra, 1994).

O conteúdo de minerais e vitaminas das plantas são condicionados, em parte, pela influência do clima e do solo, respeitando-se também o limite da constituição genética das variedades. Nota-se que as práticas de fertilização têm um importante efeito no solo, e conseqüentemente sobre as plantas que nele se desenvolvem (Calvert, 1986).

Com freqüência é registrado pela população que a qualidade dos produtos tem decrescido com a passagem dos anos. Há indivíduos que garantem que os alimentos produzidos em outras épocas apresentavam melhor sabor e maior durabilidade. Vale registrar que a veracidade desses argumentos fica restrita à subjetividade daqueles que experimentaram tais mudanças. A forma pela qual uma técnica de cultivo (neste caso adubação) influencia a qualidade do produto, deve ser constatada por meio de pesquisas científicas (Peña, 1996). 
De acordo com Calvert (1986), existem dois importantes aspectos a serem observados quando se compara o método de produção convencional e o orgânico: o nível de elementos considerados benéficos para saúde e o conteúdo de elementos produzidos prejudiciais à saúde.

\subsubsection{Conteúdo nutricional dos alimentos orgânicos}

Vários estudos citados por Lampkin (1990) mostram que ocorrendo aumento da aplicação de fertilizante nitrogenado no solo, os resultados observados foram altos níveis de nitrato, oxalatos e outros compostos indesejáveis, assim como menor teor da vitamina C nos alimentos cultivados nesses solos. Os conteúdos de cálcio, fósforo, magnésio e sódio dos alimentos também foram afetados, em decorrência dos fertilizantes empregados. Análises comparativas dos alimentos produzidos de forma orgânica e convencionalmente têm, de acordo com o referido autor, em muitos casos, confirmado as diferenças observadas no tocante ao conteúdo nutricional.

Segundo Aubert (1981), a análise das hortaliças obtidas por meio da produção biológica em comparação com as outras formas, revelou que o cultivo orgânico foi responsável por um acréscimo de $26 \%$ de matéria seca, $49 \%$ de magnésio, $290 \%$ de ferro, $35 \%$ de aminoácidos essenciais, e, inversamente, uma redução de $69 \%$ de nitrato.

Smith (1993), durante período de dois anos, determinou o teor de minerais em alimentos adquiridos em várias lojas dos subúrbios da cidade de Chicago. As frutas (maçãs e pêras), batatas e milho foram selecionados, entre amostras de alimentos convencionais e orgânicos, de variedades e tamanhos similares. Os resultados revelaram que, nos alimentos orgânicos, as concentrações são superiores quando se considera os seguintes minerais: cálcio (63\%), ferro (59\%), magnésio (138\%), fósforo (91\%), potássio (125\%), zinco (72,5\%), sódio (159\%) e selênio (390\%). Inversamente, foi verificado, menor conteúdo de alumínio (40\%), chumbo (29\%) e mercúrio (25\%).

O estudo de Smith (1993) sugere que existem diferenças significativas, quando se estabelece a comparação entre a composição dos alimentos orgânicos e convencionais. As pêras, maçãs, batatas e milhos orgânicos, integrantes da amostra, 
possuíam maior quantidade de nutrientes, quando comparados aos alimentos convencionais similares.

Ainda de acordo com o referido autor, fatores como nutrientes disponíveis, textura e matéria orgânica do solo, e ainda outros como temperatura, luz, tipo de semente, época de plantio e colheita, assim como manuseio de pós-colheita, impõesm dificuldades e limitações para viabilizar a reprodutibilidade da pesquisa.

Pesquisa realizada por Schuphan (1974) na Alemanha, durante um período de 12 anos, visou a comparação entre dois padrões de aplicação de fertilizantes na produção de espinafre, batata, cenoura e repolho. Em um processo, foi utilizado um fertilizante convencional de alta solubilidade contendo NPK (Nitrogênio, Fósforo e Potássio) e no outro, adotado o uso de adubo orgânico. Os resultados revelaram que houve um decréscimo de $24 \%$ na produção quando se utilizou adubo orgânico. No entanto, ao examinar os demais resultados, obtidos para os alimentos cultivados com a aplicação da adubação orgânica, observou-se o acréscimo de matéria seca (23\%), proteína (18\%), vitamina C (28\%), açúcares totais (19\%), metionina (23\%), ferro (77\%), potássio (18\%), cálcio $(10 \%)$ e fósforo $(13 \%)$. Inversamente, somente foi verificado decréscimo do sódio (12\%) e do nitrato (93\%).

Embora a produção absoluta tenha sido menor com o uso dos adubos orgânicos, o substancial aumento da matéria seca, vitaminas e componentes minerais, resultou em um alimento de maior valor nutricional. Essa pesquisa focalizou a importância do tema envolvendo a "máxima produção versus qualidade". A fertilização visa basicamente aumentar a produção, mas este objetivo pode não ser compatível com um produto de melhor qualidade e, como apresentado por Calvert (1986), existe a necessidade de dedicar maior atenção para outros fatores, além do rendimento da produção. Ainda de acordo com esse autor, pesquisa similar foi realizada na Suécia, com duração de 18 anos, com vistas à comparação entre sistemas de produção orgânica e convencional. Entre os principais resultados o autor ressalta as diferenças observadas na qualidade de batatas.

Em estudo implementado durante 21 anos na Europa Central, estabelecendo a comparação entre performance agronômica e ecológica dos sistemas de produção orgânico e convencional, Maeder et al. (2002) observaram colheitas com produção $20 \%$ 
menor, quando se adotou o sistema orgânico. No entanto vale enfatizar que a quantidade de insumos, utilizados nesse sistema, como os fertilizantes foi reduzida de 34 a $53 \%$ e dos defensivos, 97\%. O aumento da fertilidade do solo e a maior biodiversidade encontrados em lotes orgânicos podem atestar que esses sistemas dependem de menor quantidade de insumos externos. Segundo os autores, o fato da utilização de insumos como NPK (Nitrogênio, Fósforo e Potássio) no sistema orgânico ser 34 a 51\% menor em comparação ao conteúdo utilizado no sistema convencional, enquanto a produção da colheita se revelou apenas $20 \%$ inferior (durante um período de 21 anos), atesta o êxito da produção orgânica. Os lotes experimentais demonstraram que o solo de manejo orgânico exibiu melhor atividade biológica. Com relação aos lucros da propriedade orgânica na Europa, foram considerados similares quando comparados aos obtidos pelas propriedades que adotavam o sistema convencional.

Lairon (1985) relata que existe consenso entre a maioria dos autores quando afirmam que a fertilização orgânica tende a induzir a presença de teores superiores de fósforo nos produtos, quando comparada com a fertilização mineral. Para a concentração de potássio em amostras procedentes de produções agrícolas, não se observa, para algumas hortaliças, aumento de teores, quando se considera o tipo de fertilizante aplicado. Teores superiores de cálcio foram identificados após a adoção da fertilização orgânica para a couve, cenoura, espinafre, alho-poró, alface e batata, ao longo dos 12 dedicados às experiências de campo, envolvendo amostras de produção orgânica. Analisado os nutrientes, presentes em cenoura, couve, batata, espinafre, alface, alhoporó, tomate, cebola e ervilha, obtidos por meio da fertilização orgânica ou mineral, não foi possível observar nenhuma diferença no conteúdo de magnésio. Por outro lado, em pesquisa distinta, teores significativamente superiores de magnésio foram observados em hortaliças procedentes da agricultura biológica.

Experiências de curta duração envolvendo o cultivo de espinafre, revelaram conteúdos superiores de ferro nos alimentos cultivados com o recebimento de fertilização orgânica, em comparação com a fertilização mineral. Teores superiores de ferro foram observados em batata, alface, nabo e couve, produzidos em áreas onde se 
adotavam as práticas da agricultura biológica, em comparação com produções convencionais (Lairon, 1985).

Ao examinar os resultados, obtidos por meio de experiências de longa duração, envolvendo adoção de fertilização orgânica ou mineral, não foi possível encontrar diferenças nos teores de ácido ascórbico em alimentos como a batata, cenoura e alface . Do mesmo modo, não foi identificada diferença no conteúdo de vitamina $\mathrm{C}$ presente em espinafre obtido em produções que empregaram um ou outro método de fertilização. Em alface, couve e alho-poró fertilizados com adubos minerais ou orgânicos, não foi possível identificar diferenças de teores dos carotenóides tiamina e riboflavina. No entanto, devido à fertilização orgânica, em detrimento da opção pela adubação mineral, foram observados teores inferiores de carotenóides em espinafre e cenoura (Lairon, 1985).

Teores superiores de metionina, cisteína e histidina foram observados quando se adotou a fertilização orgânica para batatas e espinafre, enquanto o ácido glutâmico foi identificado em menor quantidade. Em cinco espécies de hortaliças procedentes de produções biológicas, houve tendência de presença de conteúdos superiores de aminoácidos essenciais, o que foi confirmado posteriormente, também quando realizouse a identificação de alguns nutrientes presentes nas batatas (Lairon, 1985).

Em pesquisa realizada por Warman \& Havard (1997), em um período de três anos, com o objetivo de avaliar a produção e o conteúdo de vitaminas e minerais de cenouras e repolhos produzidos orgânica e convencionalmente, os autores concluiram que a produção e o conteúdo de vitaminas não foram afetados pelos dois tratamentos. Porém, os teores de cinco elementos minerais (nitrogênio, enxofre, manganês, cobre e boro) em raízes de cenoura e dois elementos (enxofre e sódio) em folhas de cenoura foram influenciados pelos tratamentos. Alterações do conteúdo de nitrogênio, manganês e zinco ocorreram em repolho. Análises de cenouras cultivadas convencionalmente revelaram um conteúdo significativamente mais elevado de nitrogênio, manganês e cobre, enquanto que as cultivadas organicamente exibiram conteúdos superiores de boro nas raízes e de sódio, nas folhas. Os autores concluíram que dado o número de fatores avaliados durante os três anos, foi possível identificar poucas diferenças na produção e 
no conteúdo de vitaminas e minerais de cenouras e repolhos cultivados pelos dois diferentes sistemas de produção.

Segundo Ormond et al. (2002), o produto orgânico não apresenta, quando comparado ao produto convencional, diferenças aparentes quando se considera a forma, cor ou sabor. Assim, o que parece levar o consumidor a optar pelo consumo do alimento orgânico é a informação sobre suas vantagens nutricionais, a ausência de toxicidade e a confiança na forma como foi produzido, ou seja, com atendimento das exigências do método de cultivo. Pode-se inferir que se trata de um produto que tem na confiança seu principal atributo.

\subsubsection{Qualidade organoléptica dos alimentos orgânicos}

Muitos consumidores, com base em informações prévias, diminuem suas exigências quanto ao atributo aparência externa, quando conscientizam-se da existência, nos alimentos, de outros atributos de maior importância. Entre os atributos, de reconhecida importância, se destaca o sabor. De acordo com Lampkin (1990), existe uma crença de que o sabor do alimento produzido organicamente é mais agradável. No entanto, o autor enfatiza que, há necessidade de se dispor de resultados obtidos por meio da implementação de maior número de pesquisas científicas, com vistas à comprovação dessa vantagem relativa do alimento produzido organicamente.

O efeito do sistema de produção no sabor não deve, porém, ser ignorado. O modo como o alimento é produzido pode influenciar a composição nutricional, assim como alterar outras características como, por exemplo, o teor de matéria seca. Tais fatores, provavelmente modificam as características de sabor e textura. No entanto, o autor enfatiza que, se o efeito é benéfico ou negativo, freqüentemente, depende das preferências particulares dos indivíduos (Lampkin, 1990).

Dados de pesquisas, conduzidas na região oeste da Alemanha, visando descrever as diferenças observadas em alimentos, quanto à qualidade, apontam para o grau de crescimento e maturidade fisiológica das colheitas como tendo um significante efeito sobre o conteúdo de alguns nutrientes, entre eles o teor de açúcar. Considerando que o 
sabor doce pode ser considerado como um importante indicativo de "sabor bom", essa característica reforça o argumento de que o alimento produzido organicamente pode revelar melhor sabor. Um estudo realizado por LINDNER $^{1}$ (1985), citado por Lampkin (1990), envolvendo grupos de 30 a 50 consumidores, não informados previamente sobre as formas de produção dos alimentos, revelou que os vegetais produzidos organicamente, sob condições experimentais, foram identificados, pelos consumidores, como "de melhor sabor".

Por meio de análises tem sido possível identificar diferenças significativas nas características de alguns produtos, como no caso das distinções organolépticas entre maçãs da variedade Golden Delicious cultivadas com a adoção dos meios orgânicos e convencionais. Observou-se que as maçãs cultivadas organicamente apresentavam consistência mais firme e receberam, dos provadores, uma nota mais elevada, quando se analisou o sabor, em relação aos frutos cultivados convencionalmente. As análises envolvendo o conteúdo de flavonóides, no entanto, revelaram-se superiores para as maçãs cultivadas organicamente. Pesquisas envolvendo tomates orgânicos, revelaram que os mesmos eram descritos, pelos provadores como tendo sabor mais doce (Inocuidad, 2000).

Análises estabelecendo a comparação entre o conteúdo nutricional do trigo cultivado de modo orgânico e o convencional demonstrou que o primeiro tem um menor conteúdo de proteínas. Tal fato pode condicionar prejuízos para as características da cocção da farinha de trigo, pois as proteínas do trigo atuam de forma decisiva no comportamento reológico da massa. O pão elaborado com o trigo orgânico apresenta coloração dourada, com maior intensidade devido à superior quantidade de açúcar e proteína, que favorecem a reação de Maillard (Inocuidad, 2000).

\subsubsection{Teor de nitrato em alimentos orgânicos}

De acordo com Zago (1996), o nitrogênio (N) absorvido pelas raízes é assimilado por meio de compostos orgânicos. Em excesso, o nitrato, que é uma das formas de $\mathrm{N}$

\footnotetext{
${ }^{1}$ LINDNER, U. Alternativer Auban: alternativer im Erwerbsgemüsebau? Gemüse, v.21, p.412-18, 1985.
} 
absorvido, armazena-se nos vacúolos das células das plantas, podendo contribuir, no caso de serem consumidos por humanos e animais, para o comprometimento da saúde. A exposição, condicionada pela ingestão de vegetais e água contendo altas concentrações de nitrato, pode ocasionar danos ao organismo, principalmente quando consumidos pelas crianças. Essa forma de $\mathrm{N}$ pode ser facilmente transformada em nitrito, desencadeando um evento, que pode ser fatal, conhecido como metamoglobiemia (falta de oxigênio no sangue).

Ainda no tocante ao aspecto toxicológico envolvido no processo de ingestão de nitrato está a formação de compostos $\mathrm{N}$-nitrosos decorrente da reação do nitrato com aminas e amidas, podendo originar alguns compostos como as nitrosaminas que, sob certas condições de exposição, atuam como agentes carcinogênicos e, provavelmente, teratogênicos. Alimentos como espinafre, beterraba, rabanete, berinjela, aipo, alface, nabo, acelga, cenoura e couve estão entre os vegetais que podem apresentar concentrações superiores a $3000 \mathrm{mg}$ de $\mathrm{KNO}_{3} / \mathrm{kg}$ de matéria fresca (Zago, 1996).

Quando se considera os efeitos, desencadeados pela ingestão, vale registrar que os nitratos bloqueiam a ação do cobre presente no sangue e provocam diminuição do conteúdo de oligoelementos, especialmente cobre, manganês e boro. Em pequenas quantidades, os oligoelementos são considerados indispensáveis para o organismo, são utilizados como catalisadores para o metabolismo de enzimas e vitaminas (Rodet, s.d.).

Geralmente, a produção de espinafre é intensivamente adubada com nitrogênio químico. Freqüentemente as espécies cultivadas são previamente selecionadas considerando-se o tipo de adubação. $\mathrm{O}$ elevado teor de nitrogênio no solo adubado não permite que a planta absorva, como seria necessário para diminuir os riscos para a saúde, somente a quantidade necessária para o seu próprio anabolismo protéico. $\mathrm{O}$ nitrogênio em excesso é depositado nas folhas sob a forma de nitratos, ou seja, na forma de sais. Durante o transporte ou após a ingestão, quando presentes nos órgãos digestivos o nitrato é reduzido a nitrito. Essa substância é tóxica aos indivíduos, pois impede a hemoglobina, presente no sangue, de transportar o oxigênio. No caso de intoxicação as crianças apresentam cianose e, nos episódios mais graves, se não forem tratadas, falecerão. De acordo com Schaumann (s.d.), geralmente não se alteram os métodos de 
cultivo, mas a indústria se esforça para eliminar dos alimentos, nas fases que antecedem o processamento parte do conteúdo de nitratos e nitritos das hortaliças (por exemplo: enlatamento ou congelamento).

Segundo Lairon (1985), a taxa de nitrato presente nas plantas cultivadas é o balanço entre a absorção dos nitratos presentes no solo (procedentes dos adubos solúveis ou pela mineralização da matéria orgânica) e a redução desses nitratos na planta. Sem minimizar a função importante de outros fatores envolvidos na acumulação de nitratos (insolação, temperatura, irrigação, variedades), foi realizada comparação entre os efeitos dos fertilizantes orgânicos ou minerais. Para melhor ilustrar os resultados obtidos pelo referido autor, apresenta-se a seguir a Quadro 1.

\begin{tabular}{|lcc|}
\hline Tipo & Orgânica & Convencional \\
\hline Batata & 191 & 265 \\
Alho-poró & 432 & 899 \\
Brócolis & 2429 & 2440 \\
Nabo & 293 & 1959 \\
Alface romana & 958 & 1695 \\
\hline
\end{tabular}

Quadro 1 - Teor de nitrato* em hortaliças cultivadas orgânica e convencionalmente.

Fonte: Lairon (1985)

Nota: ${ }^{*} \mathrm{em} \mu \mathrm{g} / \mathrm{kg}$

A fertilização mineral, tendo como base os resultados apresentados por Lairon (1985), é responsável pelos teores mais elevados de nitratos, quando comparada com a fertilização orgânica (composto e esterco). Shuphan (1974) obteve resultados que revelaram conteúdos de nitratos $93 \%$ menores quando se utilizou o composto biodinâmico ou composto de esterco, em comparação com o uso de adubos minerais. Para hortaliças folhosas (alface), tem sido observado, por meio da realização de experimentos de curta duração, teores inferiores da referida substância, quando se adota a fertilização orgânica. 
Em experiências com hortaliças, envolvendo a fertilização orgânica, têm sido observado teores inferiores de nitrato, especialmente em acelga, alho-poró, couve, nabo, cenoura e batata (Lairon, 1985).

De acordo com Lairon (1985), os teores de nitrato identificados em amostras de hortaliças obtidas por meio de produção agrícola biológica, implementada na França, Suíça, Áustria e Países Baixos, foram aproximadamente a metade daqueles obtidos pelo método convencional.

Pesquisa realizada na Alemanha visou avaliar comparativamente, as modificações que surgiram, em hortaliças, ao longo do período de armazenamento. Assim, espinafres fertilizados organicamente (com 81,9\% menos nitratos no momento da colheita do que aqueles fertilizados com adubos minerais), continham menor conteúdo de nitritos, após cinco $(50,8 \%)$ e nove $(60,1 \%)$ dias de armazenamento (Lairon, 1985).

Substanciais quantidades de aplicações de adubo contendo nitrogênio solúvel resultam em nitratos na água do solo e, indevidamente, altos níveis de nitrato nos vegetais. Espinafre e outros vegetais verdes têm, naturalmente, um alto nível de nitrato, mas esse é intensivamente aumentado pela aplicação de fertilizante com nitrogênio solúvel. Alterações na metamioglobina (freqüentemente quebra) e desordem da circulação sanguínea, especialmente em crianças, e possíveis ligações entre alta quantidade de nitrato e câncer de estômago e esôfago têm sido demonstradas por meio de diversas pesquisas epidemiológicas. $\mathrm{O}$ uso de adubos processados (compostos) e apropriada rotação de cultura resultam em regular suprimento de nitrogênio e redução nos níveis de nitrato presentes na planta (Calvert, 1986).

Graves problemas de segurança alimentar podem ser condicionados pelas transformações do nitrato em nitrito, que ocorrem em todas as etapas do processo (período compreendido entre a colheita e o consumo, inclusive nos processos metabólicos, no organismo humano). A possível síntese de nitrosaminas carcinogênicas a partir de nitritos e várias aminas como, por exemplo, as procedentes dos pesticidas são motivos de alerta e preocupações por parte dos especialistas (Lairon, 1985). 
Tendo em vista a importância do tema, universidades de vários países , passaram a estabelecer linhas de pesquisa, visando a avaliação dos alimentos obtidos por meio de produção orgânica, sendo exemplo dessa iniciativa The Royal Veterinary and Agricultural University, da Dinamarca (www.kvl.dlk).

\subsection{Resíduos de agroquímicos em alimentos}

O Brasil é o quarto maior mercado de agroquímicos ou defensivos químicos sintéticos no mundo e o oitavo, quando se considera a utilização por área cultivada. Até setembro de 1999, 322 ingredientes ativos tiveram seu uso agrícola aprovado no País, envolvendo, também, cerca de 2000 produtos registrados, entre os quais inseticidas, fungicidas, herbicidas, acaricidas, reguladores de crescimento, feromônios, moluscicidas e protetores de sementes. No entanto, a legislação brasileira não exige, como prérequisito para o registro desses produtos, a realização de estudos de avaliação de risco. Também não se dispõe no Brasil de análises envolvendo o impacto para a saúde decorrente da ingestão de agroquímicos contidos nos alimentos que integram a dieta (Caldas \& Souza, 2000).

No Brasil, existem normas que visam a regulamentação do uso de defensivos na agricultura, mas, salvo em alguns estados, que dispõem de fiscalização efetiva, a obediência às leis ainda esbarra em questões sócio-culturais específicas de cada região (Araújo et al., 2000).

A presença de resíduos de defensivos em alimentos, somada à contaminação da água, constituem risco para a população em geral e representam, sem dúvida, um grande problema de saúde pública no Brasil. Com o objetivo de obter melhor conhecimento da situação, foi estudada a utilização de defensivos em tomates produzidos no estado de Pernambuco. Outras motivações referem-se ao fato da grande importância socioeconômica da cultura desses frutos e o potencial risco epidemiológico relacionado à saúde dos consumidores, dos referidos alimentos. No modelo dominante de produção, a cultura do tomate demanda uso intensivo de agroquímicos e esse fruto integra o hábito alimentar da população em geral (Araújo et al., 2000). 
De acordo com os referidos autores, as regiões integrantes da pesquisa careciam, indiscriminadamente, de ações que visassem à proteção da saúde dos trabalhadores rurais, que lidavam com os defensivos e, também, de medidas visando a proteção do meio ambiente, que se revelou gravemente comprometido. Os autores relataram ainda que, produtos sem registro autorizado para o uso na produção de tomates, era prática comum entre os agricultores e que a situação era agravada pelo fato de não existir qualquer tipo de controle sistemático da presença de resíduos de defensivos nos alimentos ou dos produtos comercializados no estado de Pernambuco. Foi observada ainda a escassez de campanhas efetivas com vistas à orientação, apoio e educação dos produtores envolvidos. Foi registrado o desconhecimento por parte dos produtores e aplicadores de defensivos no que se refere aos efeitos tóxicos para a saúde e o meio ambiente, associados ao uso indevido dos produtos não-autorizados.

Caldas \& Souza (2000) a partir de dados de consumo de alimentos registrados pela Pesquisa de Orçamentos Familiares, realizada pelo IBGE, em 1995-96, identificaram os alimentos que mais contribuíram para a Ingestão Diária Máxima Teórica (IDMT) de pesticidas. O cereal (arroz) e a leguminosa (feijão) de alto consumo pela população brasileira, as frutas, principalmente as cítricas, e o tomate foram alimentos que exerceram papel preponderante para a elevação da ingestão.

Vale registrar que o consumo de alimentos seguros significa a promoção da saúde e manutenção da qualidade de vida da população. A garantia de alimento livre de contaminantes é essencial para a prevenção de doenças, principalmente em um país como o Brasil, onde uma parte considerável da população enfrenta sérios problemas de carência nutricional e de acesso ao sistema público de saúde (Caldas \& Souza, 2000).

\subsection{Alimento Orgânico: o caso do tomate}

Sob a denominação "alimentos orgânicos", incluem-se todos os produtos alimentícios (inclusive ervas medicinais) obtidos por meio da adoção de técnicas orgânicas e sob normas da agricultura orgânica, sendo processados, manufaturados, 
embalados, estocados e transportados atendendo critérios específicos, de modo a preservar o máximo de sua qualidade (Paschoal, 1994).

De acordo com a Food Agriculture Organization (FAO) e World Health Organization (WHO) integrantes do Codex Alimentarius, considerar-se-á que um produto deva registrar indicações referentes aos métodos de produção orgânica quando, na etiqueta ou na declaração de propriedade, incluindo o material publicitário e os documentos comerciais, o produto e seus ingredientes estejam descritos mediante os termos: "orgânico", "biodinâmico", "biológico", "ecológico", ou similar, sugerindo ao comprador que os produtos são obtidos mediante métodos de produção orgânica. Além disso, todos os materiais e/ou produtos produzidos a partir de organismos modificados geneticamente (OMG) são incompatíveis com os princípios da produção orgânica e não são aceitos como integrantes dessas diretrizes (FAO/OMS, 1999).

Paschoal (1994) chama a atenção para a crescente demanda de alimentos produzidos organicamente. De acordo com o autor o alimento orgânico deve apresentar qualidade biológica, nutritiva e ainda, ser isento de resíduos químicos de agrotóxicos, de fertilizantes minerais solúveis, de hormônios, de antibióticos e de outras drogas veterinárias. Ainda de acordo com Paschoal (1994), no eventual processamento ou manufaturamento desse tipo de alimento, não é recomendado o emprego de aditivos químicos. Tal situação impõe a adoção de medidas disciplinares dirigidas tanto para o setor produtivo, como para os setores industrial e comercial. Desse modo, procura-se assegurar a autenticidade desses produtos para atender as preferências e investimentos do consumidor.

É importante destacar que a população brasileira reconhece no tomate diversos atributos, entre eles os nutricionais e, especialmente, versatilidade culinária. Mais recentemente tem sido recomendado o seu consumo, principalmente em decorrência de pesquisas que revelam a presença de substâncias presentes em sua composição que exercem papel preventivo, especialmente contra as doenças crônicas.

Face ao exposto, julgou-se pertinente incluir no presente trabalho o tomate, como alvo de análise. 
O tomate é uma planta da família das solanáceas, cuja espécie básica é denominada cientificamente Lycopersicum esculentum Mill. O centro primário de origem do tomate e das espécies silvestres aparentadas é o Geocentro Sul-Americano, que abrange as regiões situadas ao longo da Cordilheira dos Andes (Espinoza, 1991).

O fruto do tomate é a parte comestível, podendo ser consumido cru ou cozido e apresentando,também, excelente palatabilidade. O seu baixo valor energético torna-o recomendável àqueles indivíduos que desejam se submeter a dietas hipocalóricas ou que necessitam consumir um alimento de fácil digestão (Minami, 1989).

A identificação de sua notável riqueza, especialmente quanto a presença de vitaminas, aliado ao seu agradável sabor e cor, contribuiu para a rápida popularização de seu consumo. O tomate é consumido in natura como o ingrediente preferido das saladas; sob a forma de suco; desidratado, como integrante de sopas; em conservas; em extrato; coado e condimentado (ketchup); ou com vinagre (picles). Os frutos verdes em alguns países são utilizados inclusive para o preparo de doces (Espinoza, 1991).

De acordo com Espinoza (1991), estatísticas publicadas pela FAO têm registrado que o tomate ocupa o terceiro lugar entre as hortaliças quanto ao volume de produção mundial, cujo índice só é superado pelos correspondentes à batata e à batata-doce.

Na América do Sul, o Brasil é o principal produtor de tomate, seguido do Chile. No ranking dos principais países produtores o Brasil ocupa a quarta posição, sendo precedido dos Estados Unidos, Itália e Grécia (Costa, 1998).

De acordo com os dados do Agrianual 2001, a região sudeste foi responsável por $52 \%$ do total da produção nacional, sendo o estado de São Paulo o maior produtor (FNP, 2001).

Segundo os dados da Pesquisa de Orçamentos Familiares de 1995 - 1996, o consumo de hortaliças frutosas (grupo no qual incluem-se abóbora comum, abobrinha, berinjela, chuchu, jiló, pepino, pimentão, quiabo, vagem e tomate) em São Paulo era de $10,6 \mathrm{~kg}$ por pessoa/ano, sendo o tomate a hortaliça mais consumida $(5,3 \mathrm{~kg}$ per capita por ano). Desse modo, merece destaque o consumo de tomate, que representa $49 \%$ do total de hortaliças frutosas consumidas na cidade de São Paulo. Esse dado é equivalente 
a média do consumo de tomate observado entre a população de outras cidades pesquisadas (Instituto, 1998).

A mesma pesquisa revelou também que o consumo de tomate cresce à medida que aumenta a renda familiar da população: o menor consumo físico foi observado entre as famílias com rendimentos até 2 salários mínimos e a maior quantidade consumida, entre os grupos populacionais integrantes ao estrato de renda entre 20 a 30 salários mínimos.

A obtenção de tomates diferenciados, em termos de tamanho, cor, vida de prateleira, formato e sabor, é um importante objetivo perseguido pelos tomaticultores. Reconhece-se também como atributo de qualidade do produto a menor quantidade de agroquímicos utilizados em seu cultivo. No tocante a esse respeito, vale salientar que há crescente pressão em favor do rastreio dos produtos por parte das grandes redes de varejo, de modo a garantir maior segurança aos consumidores. Para muitos produtores de tomates, atentos à essa tendência, passou a ser prioritária a produção e oferta de um produto considerado mais saudável para o consumo, como pré requisito para viabilizar o acesso aos mercados integrados por consumidores mais exigentes (FNP, 2001).

Segundo Farina \& Rezende (2001), o Sistema Brasileiro Agroindustrial do tomate orgânico oferece um excelente exemplo da importância da coordenação do sistema para o êxito da adoção de um padrão de competição baseado em atributos de qualidade. $\mathrm{O}$ tomate é um produto cuja produção convencional reconhecidamente utiliza elevadas quantidades de agroquímicos, sendo também um alimento amplamente consumido in natura. O referido alimento é altamente sensível à contaminação por agroquímicos e microrganismos. Por ser consumido freqüentemente cru, pode acarretar prejuízos à saúde do consumidor.

A salada de tomate orgânico pode custar cinco vezes mais do que a preparado com tomate convencional. $\mathrm{O}$ alcance desse preço elevado com relação ao produto convencional depende muito da credibilidade do sistema de produção orgânico. Como o consumidor paga um preço mais elevado para obter um alimento seguro e não apenas pela ausência de agroquímicos, casos de contaminação que eventualmente venham ocorrer podem comprometer o prestígio da marca utilizada pela firma que comercializa 
os vegetais orgânicos. Tal situação pode ainda comprometer decisivamente o desenvolvimento deste mercado (Farina \& Rezende, 2001).

Pesquisas indicam que as questões de segurança alimentar, particularmente resíduos de pesticidas em alimentos, constituem importante preocupação para os consumidores. Enquanto os números revelam variação, dependendo das pesquisas, na maior parte dos casos, os resíduos de químicos se destacam, situando-se próximo ao topo da lista de preocupações, registradas pelos consumidores, com a segurança alimentar (Underhill \& Figueroa, 1996). 


\section{MATERIAL E MÉTODOS}

Antecedendo a apresentação dos módulos que integram esta seção, registra-se que, durante a seleção das amostras do alimento foi assegurado um controle de fatores que visou evitar que a análise comparativa dos produtos fosse afetada por características não inerentes ao tipo de cultivo. São exemplos dessa situação: cultivar do tomate, região de produção, época de plantio, grau de maturação, condições de transporte, embalagens adotadas, exposição à umidade, calor e luz, entre outras.

\subsection{Material}

Para o desenvolvimento dessa pesquisa, foram utilizados frutos de tomate (Lycopersicum esculentum Mill) dos cultivares Carmem e Débora, produzidos pelos métodos de cultivo orgânico e convencional, destinados ao consumo à mesa.

Os lotes, contendo $10 \mathrm{~kg}$ de cada um dos cultivares dos frutos produzidos organicamente foram obtidos diretamente do produtor, no município de Ibiúna - estado de São Paulo. O produto apresentava certificação do Instituto Biodinâmico de Botucatu IBD para a comercialização com a denominação de produto orgânico e tinha como destino o mercado, por meio de uma distribuidora de produtos orgânicos para grandes redes varejistas de supermercados. Os lotes de $10 \mathrm{~kg}$ dos cultivares Carmem e Débora produzidos convencionalmente provenientes do município de Guapiara (região de Capão Bonito) - estado de São Paulo, foram adquiridos diretamente do produtor no entreposto do Ceasa do município de Piracicaba, estado de São Paulo. Os frutos foram colhidos quando atingiram o ponto comercial denominado "salada", se baseando na classificação 
pela cor, determinada pela Companhia de Entrepostos e Armazéns Gerais do Estado de São Paulo (s.d.) (CEAGESP), e adotada pelos produtores.

Tendo por base o período de plantio e colheita dos frutos dos cultivares Carmem e Débora, os produtores de tomates orgânicos e convencionais foram selecionados. Tal procedimento foi necessário, tendo em vista a importância de se dispor de alimentos cuja época de plantio e, também, de colheita, fossem coincidentes, para os dois métodos de cultivo (Tabela 1).

Tabela 1. Datas de plantio e de colheita dos tomates dos cultivares Carmem e Débora, produzidos por meio de cultivo orgânico e convencional.

\begin{tabular}{lllll}
\hline Cronograma & $\begin{array}{l}\text { Carmem } \\
\text { Convencional }\end{array}$ & $\begin{array}{l}\text { Carmem } \\
\text { Orgânico }\end{array}$ & $\begin{array}{l}\text { Débora } \\
\text { Convencional }\end{array}$ & $\begin{array}{l}\text { Débora } \\
\text { Orgânico }\end{array}$ \\
\hline Data do plantio & $01 / 01 / 2002$ & $15 / 12 / 2001$ & $20 / 12 / 2001$ & $15 / 12 / 2001$ \\
Data da colheita & $30 / 03 / 2002$ & $30 / 03 / 2002$ & $30 / 03 / 2002$ & $30 / 03 / 2002$
\end{tabular}

Fonte: informações fornecidas pelos produtores.

Foram selecionados os cultivares destinados à mesa Carmem e Débora, para a realização da pesquisa, por se tratarem de cultivares amplamente comercializados e consumidos pela população do estado de São Paulo.

Os tomates foram transportados, um dia após a colheita, em caixas plásticas a temperatura ambiente até o laboratório do Setor de Processamento de Alimentos do Departamento de Agroindústria, Alimentos e Nutrição da Escola Superior de Agricultura "Luiz de Queiroz" - Universidade de São Paulo, onde foram mantidos, sob refrigeração, a temperatura de $5^{\circ} \mathrm{C}$ (variação de $\pm 1^{\circ} \mathrm{C}$ ). Os lotes foram transportados e armazenados sob as mesmas condições de exposição ao calor, luz e umidade.

As diferentes análises foram realizadas simultaneamente para cada cultivar, obtido pelos dois métodos de cultivo, para que a comparação não fosse prejudicada pela influência de outras variáveis que não o método de cultivo. 


\subsection{Amostragem}

Para a obtenção da amostra os frutos foram escolhidos, ao acaso, sendo coletadas, diferentes quantidades que serão apresentadas na seção reservada à descrição das análises.

O experimento foi caracterizado pelo delineamento inteiramente casualizado, com quatro tratamentos (Carmem convencional, Carmem orgânico, Débora convencional e Débora orgânico) e os resultados das análises, foram expressos pela média obtida por meio das repetições, realizadas para cada análise.

\subsection{Caracterização dos tomates}

\subsubsection{Análises físico-químicas}

As análises físicas de firmeza da polpa e cor, descritas a seguir, foram realizadas no Laboratório de Irradiação de Alimentos e Radioentomologia do Centro de Energia Nuclear na Agricultura (CENA) - Universidade de São Paulo - Campus de Piracicaba, durante o segundo dia de armazenamento dos frutos, sob refrigeração.

a) Firmeza da polpa: a textura foi determinada com penetrômetro digital, ponteira $8 \mathrm{~mm}$ e os resultados expressos em Newton.

b) Cor: determinada através de colorímetro Minolta Chroma Meter CR 200b, com a seguinte configuração: sistema colorimétrico L C h. Os resultados foram expressos em ângulo de cor $\left({ }^{\circ} h\right)$ e croma para cor da casca. $\mathrm{O} \mathrm{h}^{\mathrm{o}}$ define a coloração básica, onde $0^{\circ}=$ vermelho, $90^{\circ}=$ amarelo e $180^{\circ}=$ verde. $\mathrm{O}$ croma define a saturação e intensidade da cor definida pelo $\mathrm{h}^{\mathrm{o}}$ (McGuirre, 1992). Duas leituras foram realizadas em lados opostos da região equatorial.

A cromaticidade da amostra foi obtida calculando-se $\mathrm{C}=\overline{\mathrm{a}^{2}+\mathrm{b}^{2}}$, que é a hipotenusa do triângulo retângulo cujos catetos são dados pelos valores "a" e "b", conforme mostrado na Figura 1. A tonalidade foi obtida através do ângulo "h" , calculado por $\operatorname{tg}^{-1} \mathrm{a} / \mathrm{b}$ (Almeida, 1995). 


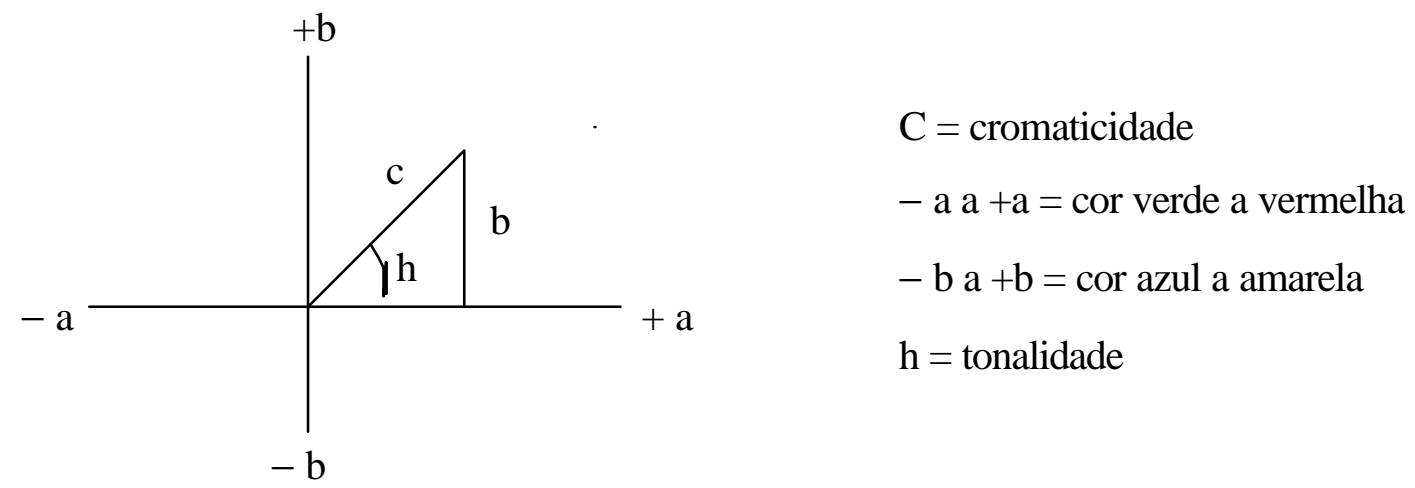

Figura 1 - Três dimensões para medir cor instrumental.

Um total de seis frutos retirados aleatoriamente de cada lote foram submetidos à análises físicas.

As determinações de $\mathrm{pH}$, acidez total titulável, teor de sólidos solúveis e teor de ácido ascórbico, descritas a seguir, foram realizadas nas dependências do Setor de Processamento de Alimentos do Departamento de Agroindústria, Alimentos e Nutrição da Escola Superior de Agricultura "Luiz de Queiroz" - Universidade de São Paulo no mesmo dia do recebimento das amostras.

c) $\mathrm{pH}$ : foi determinado, na amostra triturada, utilizando-se um potenciômetro digital, Alphalab modelo PA-200. Os resultados foram expressos em unidades de pH (AOAC, 1995).

d) Acidez total titulável: foi determinada segundo método de referência número 22060 da "Association of Official Analytical Chemists" - AOAC (1995), conforme descrito a seguir: amostras de $10 \mathrm{~g}$ foram trituradas com $90 \mathrm{ml}$ de água destilada e, a seguir, tituladas rapidamente e sob agitação, com solução $0,01 \mathrm{~N}$ de hidróxido de sódio $(\mathrm{NaOH})$ padronizado, até atingir a coloração rósea tendo como indicador a fenolftaleína $1 \%$. Os resultados foram expressos em $\mathrm{mg}$ de ácido cítrico por $100 \mathrm{~g}$ de amostra. O ácido presente em maior quantidade nos frutos do tomate é o ácido cítrico. 
e) Teor de sólidos solúveis: foram determinados os teores de sólidos solúveis totais, utilizando-se o refratômetro Atago, modelo N-1, homogeneizando-se a amostra em liquidificador doméstico com transferência de 1 ou 2 gotas para o prisma do refratômetro, desprezando-se partículas grandes de polpa. Os resultados foram expressos em ${ }^{\circ}$ Brix.

f) Teor de ácido ascórbico: foi determinado pesando-se $10 \mathrm{~g}$ de polpa triturada e homogeneizada e diluindo-se em $90 \mathrm{~mL}$ de ácido oxálico 0,4\%. Após agitação para homogeneização, foi tomada uma alíquota de $2 \mathrm{~mL}$ para erlenmeyer de 125 $\mathrm{mL}$ e adicionados $50 \mathrm{~mL}$ de água destilada, que na seqüência foi titulada com Reativo de Tillmans (2,6 diclorofenol-indofenol), até a obtenção de uma coloração ligeiramente rosada e estável por 15 segundos. Os teores de ácido ascórbico das amostras foram calculados tomando-se por base um padrão de ácido ascórbico, previamente determinado. Os resultados foram expressos em $\mathrm{mg}$ de ácido ascórbico por 100g de amostra (Pregnolatto \& Pregnolatto, 1985).

As análises químicas descritas anteriormente foram realizadas, envolvendo três repetições, tendo como base amostras retiradas, ao acaso, dos diferentes lotes de frutos.

As análises para a determinação do teor de $\beta$-caroteno e licopeno foram realizadas nos laboratórios do Instituto de Tecnologia de Alimentos (ITAL), Campinas SP, ao longo do segundo dia de armazenamento dos frutos, sob refrigeração.

g) $\beta$-caroteno: a determinação das concentrações de $\beta$-caroteno foi baseada no procedimento proposto por Carvalho et al. (1992). Esse procedimento constitui-se, basicamente, de uma extração seguida de cromatrografia em coluna para separação do pigmento e leitura em espectofotômetro. Os resultados foram expressos em microgramas de $\beta$-caroteno por $100 \mathrm{~g}$ de amostra.

h) Licopeno: a determinação das concentrações de licopeno foi baseada no procedimento proposto por Carvalho et al. (1992). Esse procedimento constitui-se, basicamente, de uma extração seguida de cromatrografia em 
coluna para separação do pigmento e leitura espectofotométrica com uso da absortividade molar específica do licopeno. Os resultados foram expressos em miligramas de licopeno por $100 \mathrm{~g}$ de amostra.

As análises químicas de $\beta$-caroteno e licopeno foram efetuadas, envolvendo duas repetições em amostras tomadas ao acaso dos quatro diferentes lotes.

Os frutos foram lavados para remover resíduos de terra e/ou poeira e encaminhados ao laboratório do Setor de Nutrição Mineral de Plantas do Departamento de Solos e Nutrição de Plantas da Escola Superior de Agricultura "Luiz de Queiroz" Universidade de São Paulo, onde foram elaboradas as análises, envolvendo a determinação da umidade e de minerais dos frutos de tomate, ao longo do quinto dia de armazenamento, sob refrigeração.

i) Umidade: foi realizada através da perda de peso da amostra aquecida a $105 \mathrm{C}$ \pm 1 C, até peso constante, de acordo com AOAC (1995).

j) Minerais: foram determinados os teores de cálcio, magnésio, enxofre, nitrogênio, fósforo, potássio, sódio, boro, cobre, ferro, manganês e zinco, adotando-se a metodologia descrita por Sarruge \& Haag (1974).

\subsubsection{Análise Sensorial}

A Análise Sensorial foi realizada no Laboratório de Análise Sensorial do Departamento de Agroindústria, Alimentos e Nutrição da Escola Superior de Agricultura "Luiz de Queiroz" - Universidade de São Paulo.

As amostras de tomate, produzidos pelos métodos de cultivo orgânico e convencional, foram avaliadas subjetivamente quanto ao aroma, sabor, cor e aspecto geral. As análises dos cultivares Débora e Carmem foram realizadas, respectivamente, após o segundo e o terceiro dia de armazenamento sob refrigeração. As avaliações foram realizadas comparando-se o mesmo cultivar de tomate produzido pelo método de cultivo orgânico e pelo método convencional. Um grupo de 34 provadores participou da análise sensorial do cultivar Débora e 48 provadores analisaram o cultivar Carmem. 
Durante o recrutamento e a seleção dos indivíduos que participaram dos testes a autora empreendeu esforços com vistas à obtenção de voluntários adultos, pertencentes a diferentes faixas etárias, assim como, distintos níveis de escolaridade e rendimentos.

As avaliações das amostras foram realizadas por equipes de provadores, constituída por graduandos, pós-graduandos, funcionários e membros do grupo da Terceira Idade da ESALQ/USP. Os provadores, que se declararam consumidores de tomate in natura, receberam orientação prévia para a realização da avaliação. Utilizou-se o Teste de Aceitabilidade em nível de consumidor, em escala hedônica de nove pontos $(9$ = gostei extremamente, $8=$ gostei moderadamente, $7=$ gostei regularmente, $6=$ gostei ligeiramente, 5 = não gostei nem desgostei, 4 = desgostei ligeiramente, $3=$ desgostei regularmente, 2 = desgostei moderadamente e 1 = desgostei extremamente), além da descrição do grau em que o alimento agradou ou desagradou, em cada amostra. Foi solicitado a cada provador para que registrasse a sua opinião para cada amostra. A ficha adotada para os registros dos provadores, relativos à avaliação dos frutos, pode ser observada no Anexo A.

Vale registrar que as escalas hedônicas são aquelas que expressam a opinião do provador, tendo por base a avaliação sensorial do produto. São consideradas as melhores escalas aquelas integradas por igual número de categorias positivas e negativas, que captam a opinião do provador. Freqüentemente essas escalas são chamadas de balanceadas (Ferreira, 2000). No caso das escalas não serem simétricas, isto é, se não forem compostas por similar número de categorias positivas e negativas, são identificadas como não-balanceadas.

Para avaliação do aroma e do sabor dos frutos, aproximadamente $30 \mathrm{~g}$ da amostra foram servidas, aos provadores, em pratos de louça branca dispostos aleatoriamente e mantidos em cabines individuais com iluminação diferenciada para mascarar a cor do fruto, havendo também no local um copo contendo água. Os pratos foram codificados com números aleatórios compostos de três dígitos.

Para avaliação do fruto inteiro, quanto à cor e ao aspecto geral utilizou-se pratos de louça branca, onde foram colocados dois frutos (por amostra), dispostos aleatoriamente. Também foram utilizadas as cabines individuais com iluminação 
fluorescente para o melhor controle da análise. Para a identificação dos pratos, adotou-se procedimento idêntico ao descrito anteriormente.

Os resultados obtidos mediante a realização da análise sensorial foram avaliados segundo delineamento experimental em blocos ao acaso, contendo quatro tratamentos (Carmem convencional, Carmem orgânico, Débora convencional e Débora orgânico), com a participação de 34 provadores para a avaliação de dois dos tratamentos (Débora convencional e Débora orgânico) e envolvimento de 48 provadores, no processo de avaliação dos outros dois tratamentos (Carmem convencional e Carmem orgânico).

\subsection{População do estudo}

Para viabilizar a realização deste módulo da pesquisa, foram recrutados os mesmos indivíduos que participaram da análise sensorial das amostras de tomate. Como descrito anteriormente, durante o recrutamento e a seleção dos indivíduos que participaram dos testes empreendeu-se esforços com vistas à obtenção de voluntários adultos, pertencentes a diferentes faixas etárias, assim como, distintos níveis de escolaridade e rendimentos. Tal preocupação justifica-se pois um item que mereceu atenção, na presente pesquisa foi a descrição do perfil dos provadores (por exemplo, quanto às condições socioeconômicas) e também quanto ao consumo de alimentos orgânicos, locais de compra, conceitos e fontes de informações sobre os referidos alimentos, disposição para pagar maior preço pelos alimentos orgânicos, entre outros.

O formulário adotado para a obtenção das informações junto aos participantes (n = 59) pode ser observado no Anexo B. A aplicação do formulário ocorreu em uma sala situada ao lado do Laboratório de Análise Sensorial do Departamento de Agroindústria, Alimentos e Nutrição da Escola Superior de Agricultura "Luiz de Queiroz" Universidade de São Paulo, imediatamente após a participação dos voluntários no processo de análise sensorial. Os participantes preencheram o formulário recebendo auxílio apenas para dirimir dúvidas relativas a interpretação de questões e, logo após a conclusão do preenchimento, efetuaram a devolução dos formulários. Vale registrar que além de atitudes e preferências, o questionário inclui itens envolvendo informações 
socioeconômicas, como por exemplo, rendimentos, educação, tamanho da família e gênero. Foram incluídas também questões visando conhecer a opinião dos participantes no tocante aos produtos orgânicos e o valor adicional que os mesmos estariam dispostos a pagar pelos referidos alimentos, objeto da presente pesquisa.

Para a construção do banco de dados utilizou-se o software SAS (1998). Para as análises descritivas e testes de associação, também foram adotados os recursos do referido software.

\subsection{Análise estatística}

As notas atribuídas, pelos provadores aos alimentos, foram submetidas à análise de variância, considerando-se tanto o efeito dos quatro tratamentos (Carmem convencional, Carmem orgânico, Débora convencional e Débora orgânico), como o efeito de provadores. Foi realizado o teste $\mathrm{F}$ para verificar a consistência da diferença entre os quatro tratamentos e o teste de Tukey adotado para comparar as médias duas a duas.

Para as análises descritivas e testes de associação das variáveis, adotou-se o $S A S$ (1998) . Visando conhecer a associação entre algumas variáveis, como exemplo renda familiar e consumo de alimentos orgânicos, foram elaboradas tabelas de contingência acompanhadas de testes de qui-quadrado. 


\section{RESULTADOS E DISCUSSÃO}

\subsection{Análises físicas}

Na Tabela 2, são apresentados os resultados da avaliação objetiva dos atributos físicos (ângulo de cor, croma e textura).

Tabela 2. Características físicas dos cultivares de tomate in natura produzidos pelo cultivo orgânico e pelo cultivo convencional.

\begin{tabular}{lcccc}
\hline & \multicolumn{4}{c}{ Média dos valores obtidos* para os cultivares } \\
\hline Características & $\begin{array}{l}\text { Carmem } \\
\text { Físicas }\end{array}$ & $\begin{array}{c}\text { Carmem } \\
\text { orgânico }\end{array}$ & $\begin{array}{l}\text { Débora } \\
\text { convencional }\end{array}$ & $\begin{array}{l}\text { Débora } \\
\text { orgânico }\end{array}$ \\
Ângulo de cor $\left({ }^{\circ} \mathrm{h}\right)$ & 66,26 & 58,64 & 56,41 & 58,27 \\
Croma $(\mathrm{C})$ & 31,53 & 32,95 & 35,39 & 36,61 \\
Textura & 8,47 & 8,85 & 9,38 & 10,28 \\
$\left(\mathrm{~N} \mathrm{x} \mathrm{10} 0^{5}\right)$ & & & & \\
\hline
\end{tabular}

* Valores que representam médias obtidas a partir de resultados de 2 determinações.

As leituras dos valores foram sistematizadas adotando-se modelo matemático para C e h, onde "C" é cromaticidade e "h" tonalidade. Almeida (1995) observou que L, $\mathrm{h}$ e $\mathrm{C}$ correlacionam-se bem com a percepção dos provadores no que se refere à cor subjetiva (sensorial). 
De acordo com Setser (1984), as análises sensoriais podem ser custosas e demoradas, difíceis de serem obtidas no tempo desejado especialmente quando se referem a amostras de alimentos perecíveis, enquanto que, na maioria das vezes, há disponibilidade de instrumentos que podem, quando empregados, fornecer resultados valiosos, em curto prazo.

O parâmetro "h" define a coloração básica das amostras e representa a tonalidade média das amostras de tomates (McGuirre, 1992). Quanto maior o ângulo de cor $\left({ }^{\mathrm{h}} \mathrm{h}\right)$ obtido significa que a cor do fruto está mais próxima do amarelo e quanto menor o ângulo, a cor se aproxima do vermelho. Portanto, os frutos do cultivar Débora convencional apresentaram maior tonalidade de vermelho do que os frutos Débora orgânico, enquanto o tomate Carmem orgânico apresentou maior tonalidade de vermelho quando comparado ao Carmem convencional.

Segundo Almeida (1995), quatro estágios de tonalidade, representados pela identificação do ângulo de cor, podem ser observados. O estágio inicial é identificado pelo fato do tomate revelar um maior ângulo de cor que ocorre durante o período entre o primeiro e o quinto dia de maturação; o estágio intermediário-I, envolve o período do oitavo ao décimo dia, quando o tomate apresenta ângulo de cor decrescente; o estágio intermediário-II, do décimo segundo ao décimo sétimo dia, passando por suave transição para o estágio final. Nesse último estágio (últimos dias do período de maturação) o tomate apresenta o menor ângulo de cor. De acordo a referida classificação pode-se dizer que os frutos analisados, na presente pesquisa, encontravam-se no mesmo estágio inicial de tonalidade, daí a observação de pequenas diferenças entre os ângulos de cor das amostras.

O parâmetro "C" de cor, que representa a cromaticidade média das amostras de tomate, define a saturação e intensidade da cor definida pelo $h^{0}$ (McGuirre, 1992).

Quanto maior o croma pode-se dizer que a cor é mais saturada e também mais intensa. Observa-se que, para os dois cultivares produzidos organicamente, o croma foi ligeiramente superior, quando comparado com os alimentos produzidos convencionalmente. Isso significa que, neste caso, a cor se revelava mais intensa nos frutos provenientes da produção orgânica. 
De acordo com Almeida (1995), de maneira geral, na determinação da cor do tomate ao longo do tempo de maturação, pode-se sugerir três estágios de cromaticidade. Um estágio inicial, quando o tomate apresenta-se com menos croma, esse refere-se ao período entre o primeiro e o oitavo dia de maturação; um estágio intermediário, quando o tomate apresenta-se com croma um pouco mais elevado, o que se espera que ocorra entre o oitavo e o décimo quinto dia de maturação; e o estágio final, quando o tomate revela o maior croma (a partir do décimo quinto dia de maturação). De acordo com essa classificação, pode-se dizer que os frutos analisados encontravam-se no mesmo estágio inicial de cromaticidade. Desse modo, foram observadas pequenas diferenças entre o croma das amostras.

Segundo Little (1973), em uma escala subjetiva as pessoas atribuiriam valores diferentes para um mesmo tomate vermelho claro, mas em uma escala analítica (objetiva) os valores seriam similares, praticamente eliminando as possibilidades de "viés analítico".

A textura é definida como o conjunto de propriedades do alimento, composto por características físicas perceptíveis pelo tato e que se relacionam com a deformação, desintegração e fluxo do alimento, sob aplicação de uma força. As sensações dos indivíduos que caracterizam a textura das frutas e hortaliças são múltiplas, sendo a sua maioria induzida por características mecânicas, embora também possam ser condicionadas por características geométricas ou químicas. As principais sensações são de dureza, maciez, fibrosidade, suculência, granulosidade, qualidade farinácea, resistência e elasticidade. De acordo com Chitarra \& Chitarra (1990), em frutos, a textura é caracterizada pela maciez.

A firmeza é um fator importante na determinação da qualidade dos frutos. Muitos frutos são, geralmente, colhidos quando exibem um dado nível de firmeza que é, utilizada freqüentemente, para estabelecer o grau de qualidade e, conseqüentemente, o preço no mercado. Frutos estocados sob refrigeração durante várias horas, geralmente apresentam um grau de firmeza maior quando comparado àqueles mantidos à temperatura ambiente (Bourne 1982). 
De acordo com Chitarra \& Chitarra (1990), a firmeza está fortemente correlacionada ao conteúdo e tipo de pectina presente nas frutas e hortaliças. As substâncias pécticas são os principais componentes químicos dos tecidos, responsáveis pelas mudanças de extura das frutas e hortaliças. À medida que os frutos amadurecem ocorre degradação das substâncias pécticas, o que pode ser facilmente observado pelo amolecimento da polpa dos referidos alimentos.

Vanegas (1987) verificou a resistência do tomate à compressão, durante o amadurecimento, utilizando o aparelho Instron Universal. A ruptura dos tomates, conservados a temperatura ambiente, foi obtida por meio da adoção de uma força média de $12 \mathrm{kgf}$ no primeiro dia e de $2,9 \mathrm{kgf}$ no $15^{\circ}$ dia de estocagem. Os tomates mantidos a $15^{\circ} \mathrm{C}$ resistiram a uma força de ruptura média de $14,5 \mathrm{kgf}$ no primeiro dia, diminuindo para 1,69 kgf no final da maturação $\left(31^{\circ}\right.$ dia). Os tomates mantidos sob temperatura de $10^{\circ} \mathrm{C}$ resistiram a uma força de ruptura de $16,8 \mathrm{kgf}$ no primeiro dia. A resistência alcançou $1,8 \mathrm{kgf}$ no $39^{\circ}$ dia.

Ainda de acordo com os dados da Tabela 2, verifica-se que a textura apresentouse mais elevada para o cultivar Débora, quando comparado ao cultivar Carmem (nos dois tipos de produção). Analisando-se os valores de textura de acordo com o método de cultivo, pode-se observar que a determinação da textura revelou valores muito similares entre o lote orgânico $(8,85)$ e convencional $(8,47)$ do cultivar Carmem. Para o cultivar Débora foram observados valores de 10,28 e 9,38 para o cultivo orgânico e convencional, respectivamente.

É possível inferir que a similaridade dos resultados, obtidos a partir da análise dos diferentes lotes de frutos, sejam decorrentes do adequado controle das condições de pré-análise das amostras selecionadas para a presente pesquisa. Cabe lembrar que, conforme descrito anteriormente, os tomates foram plantados praticamente na mesma época e colhidos simultaneamente. Assim, havia a expectativa que os frutos encontravam-se no mesmo grau de amadurecimento e que as substâncias pécticas, responsáveis pelas mudanças de textura das frutas e hortaliças, atuando no mesmo estágio de degradação. Uma outra condição a ser destacada refere-se ao transporte e armazenamento em condições idênticas e, também, a manutenção dos frutos sob 
refrigeração. Tais condições podem ter sido responsáveis pela manutenção do grau de firmeza dos frutos.

\subsection{Análises físico-químicas}

Os resultados das determinações do teor de vitamina $\mathrm{C}$, licopeno, $\beta$-caroteno, $\mathrm{pH}$, acidez total titulável e do teor de sólidos solúveis ( ${ }^{B}$ Brix) dos frutos são apresentados, a seguir (Tabela 3).

Tabela 3. Características químicas, vitamina $\mathrm{C}$, licopeno, $\beta$-caroteno, $\mathrm{pH}$, acidez total titulável e do teor de sólidos solúveis, dos cultivares de tomate in natura produzidos pelo cultivo orgânico e convencional.

\begin{tabular}{lcccc}
\hline \multicolumn{4}{c}{ MÉDIA DOS VALORES* } \\
\hline ANÁLISES & $\begin{array}{l}\text { Carmem } \\
\text { convencional }\end{array}$ & $\begin{array}{l}\text { Carmem } \\
\text { orgânico }\end{array}$ & $\begin{array}{l}\text { Débora } \\
\text { convencional }\end{array}$ & $\begin{array}{l}\text { Débora } \\
\text { orgânico }\end{array}$ \\
$\begin{array}{l}\text { Teor de vitamina C } \\
(\mathrm{mg} / 100 \mathrm{~g})\end{array}$ & 21,9 & 22,9 & 28,9 & 24,9 \\
$\begin{array}{l}\text { Licopeno } \\
(\mathrm{mg} / 100 \mathrm{~g})\end{array}$ & 2,9 & 2,5 & 3,5 & 3,7 \\
$\begin{array}{l}\beta \text {-caroteno } \\
(\mu \mathrm{g} / 100 \mathrm{~g})\end{array}$ & 185,5 & 132,1 & 227,8 & 233,8 \\
$\begin{array}{l}\text { Acidez titulável } \\
(\mathrm{mg} \text { ac.Cítrico/100g) }\end{array}$ & 428,8 & 405,3 & 330,7 & 377,6 \\
pH & 4,4 & 4,3 & 4,3 & 4,2 \\
$\begin{array}{l}\text { Sólidos Solúveis } \\
\left({ }^{\circ} \text { Brix) }\right.\end{array}$ & 4,7 & 4,2 & 4,9 & 4,9 \\
\hline
\end{tabular}

* Os valores representam médias obtidas a partir de dados relativos a 3 determinações do teor de vitamina $\mathrm{C}$ e acidez titulável. Os valores de licopeno, $\beta$-caroteno, $\mathrm{pH}$ e sólidos solúveis representam médias obtidas a partir de 2 determinações. 
Os teores de vitamina $\mathrm{C}$ relativos aos dois cultivares estudados Carmem $(21,9$ $\mathrm{mg} / 100 \mathrm{~g}$ e 22,9 mg/100g) e Débora (28,9 mg/100g e 24,9 mg/100g) produzidos, respectivamente por meio do método convencional e orgânico, revelaram-se abaixo do valor médio de 34,3 mg/100g observado para o tomate nacional. O referido valor está registrado na Tabela de Composição Nutricional de Hortaliças elaborada pela Embrapa Hortaliças (Luengo et al. 2000).

Verificou-se que o tomate Carmem produzido organicamente apresentou um teor de vitamina $\mathrm{C}$ mais elevado $(22,9 \mathrm{mg} / 100 \mathrm{~g})$ quando comparado ao resultado obtido por meio da análise do tomate produzido convencionalmente. Para o cultivar Débora foi identificado um teor de vitamina C superior $(28,9 \mathrm{mg} / 100 \mathrm{~g})$ ao encontrado tendo por base as amostras de frutos produzidos convencionalmente.

Perdas substanciais de nutrientes, especialmente de vitamina $\mathrm{C}$, podem ocorrer durante o armazenamento, contribuindo também para a variação na composição do fruto (Chitarra, 1994). Vale enfatizar que, na presente pesquisa, os frutos foram armazenados sob as mesmas condições e as análises (de amostras da totalidade dos lotes) realizadas simultaneamente. Tal procedimento assegurou o controle das características referentes à preservação do conteúdo de vitamina $\mathrm{C}$.

Os teores de licopeno obtidos para o cultivar Carmem foram de 2,9 e 2,5 $\mathrm{mg} / 100 \mathrm{~g}$, quando se analisou os frutos produzidos pelo cultivo orgânico e convencional, respectivamente. Wilberg \& Rodriguez-Amaya (1993) obtiveram valor de 2,4 mg/100g, quando analisaram os frutos de tomate in natura, provenientes do estado do Rio de Janeiro. Nesta pesquisa, o cultivar Débora apresentou teores de licopeno superiores $(3,5$ e 3,7 mg/100g), quando comparados com os valores citados anteriormente. Observou-se uma pequena diferença entre os teores de licopeno verificados a partir da análises dos frutos do cultivar Débora, obtidos por meio da agricultura orgânica $(3,5 \mathrm{mg} / 100 \mathrm{~g})$ e pela produção convencional $(3,7 \mathrm{mg} / 100 \mathrm{~g})$.

Estabeleceu-se uma comparação entre o ângulo de cor $(\mathrm{h})$ e o teor de licopeno obtidos por meio das análises físico-químicas. Observou-se que os ângulos de cor foram maiores para o cultivar Carmem, indicando que os frutos apresentaram uma menor tonalidade de vermelho quando comparados aos frutos do cultivar Débora. Os teores 
licopeno, carotenóides que são substâncias que conferem coloração vermelha aos frutos, revelaram-se inferiores $(2,9$ e 2,5 mg/100g) nos frutos do cultivar Carmem. Desse modo, infere-se que existe coerência entre os dados obtidos na presente pesquisa, à medida que por meio da adoção de dois parâmetros foi possível verificar a existência de diferenças entre a coloração dos tomates analisados.

Os teores de $\beta$-caroteno dos frutos registrados na Tabela 3 revelam que o conteúdo encontrado nos frutos Carmem foi de 132,1 ìg/100g para os cultivados organicamente e de 185,5 ìg /100g para os obtidos pela produção convencional. Para o cultivar Débora o conteúdo de $\beta$-caroteno foi de 233,8 ìg /100g e de 227,8 ì g/100g, quando se considera as amostras de frutos produzidos organicamente e convencionalmente. Segundo Rodriguez-Amaya (1985), as alterações do conteúdo de $\beta$ caroteno nas frutas podem ser decorrentes das variedades cultivadas, do tipo de solo, das condições climáticas e/ou geográficas e do estágio de maturação da fruta no momento da colheita. Tendo por base os referidos fatores, pode-se afirmar que na presente pesquisa, foram devidamente controladas as variáveis relativas às variedades e o estágio de maturação no momento da colheita.

A acidez dos cultivares em estudo foi analisada considerando-se o $\mathrm{pH}$ e a acidez total titulável (g ácido cítrico/100g do fruto). De acordo com Chitarra \& Chitarra (1990), os ácidos orgânicos encontram-se dissolvidos nos vacúolos das células, tanto na forma livre, como combinada com sais, ésteres e glicosídeos. Em frutas, os ácidos orgânicos (porque alguns componentes são voláteis), não só contribuem para a acidez como também para o aroma característico.

Os teores de ácido cítrico obtidos por meio de análises das amostras do tomate Carmem foram elevados (428,8 e 405,3 mg/100g) com relação aos valores encontrados (330,7 e 377,6 mg/100g) para o cultivar Débora. Pode-se observar uma discreta diferença (428,8 e 405,3 mg de ácido cítrico/100g amostra) nos dados obtidos para o tomate Carmem convencional e orgânico, respectivamente, assim como também para o tomate Débora (330,7 e 377,6 mg de ácido cítrico/100g amostra), quando se considera, a produção convencional e orgânica, respectivamente. Os valores de $\mathrm{pH}$ obtidos foram, em geral, semelhantes para os dois cultivares de tomate produzidos por meio da adoção 
dos dois métodos de cultivo. A acidez e o pH são fatores de extrema importância quando se analisa o nível de aceitação de um produto. Quando o fruto se revela excessivamente ácido é rejeitado para o consumo, principalmente pela população brasileira, cujo hábito parece priorizar o consumo de alimentos isentos dessa característica.

Os sólidos solúveis totais (Tabela 3) representam a percentagem (em peso) de sólidos que se encontram dissolvidos no alimento. São registrados em ${ }^{\circ}$ Brix, no caso de frutas, e têm a tendência exibir maior concentração com a evolução da maturação, devido aos processos de biossíntese ou ainda pela degradação de polissacarídeos. Segundo Chitarra \& Chitarra (1990), o referido parâmetro químico representa uma das melhores formas de avaliação do grau de doçura do produto. Note-se que o teor de açúcares normalmente representa, de 65 a $85 \%$ do teor de sólidos solúveis totais presentes no alimento.

As análises do cultivar Débora revelaram o mesmo valor de sólidos solúveis $\left(4,9^{\circ}\right.$ Brix) para os dois métodos de cultivo. O cultivar Carmem revelou teor mais elevado de sólidos solúveis, quando cultivado convencionalmente $\left(4,7^{\circ}\right.$ Brix), enquanto as análises do alimento cultivado organicamente revelaram $4,2^{\circ}$ Brix.

O ratio (razão), valor obtido por meio da divisão de graus Brix pela acidez total titulável, fornece uma indicação da acidez do fruto. Desse modo, quando se obtém ratio baixo, há indicação de que se trata de um fruto ácido (indicador da maturação do fruto). Quando se observa um elevado valor do ratio, mais avançado é o estado de maturação. Tais condições influenciam diretamente o sabor dos frutos. Os valores encontrados para o tomate Carmem orgânico $(0,010)$ e convencional $(0,011)$ são praticamente idênticos. As análises envolvendo o tomate Débora revelaram valores de 0,013 e 0,015 para o cultivo orgânico e convencional, respectivamente. De maneira geral, o cultivar Carmem apresentou valores $(0,010$ e 0,011) menores que o cultivar Débora. Quando se considera o método de cultivo, os valores obtidos foram similares para os dois cultivares.

Os resultados das determinações dos teores de umidade e minerais dos frutos são apresentados na Tabela 4. 
Tabela 4. Características químicas, umidade (expressa em percentagem) e minerais $(\mathrm{mg} / 100 \mathrm{~g})$, dos cultivares de tomate in natura produzidos pelo cultivo orgânico e convencional.

\begin{tabular}{|c|c|c|c|c|}
\hline \multicolumn{5}{|c|}{ CULTIVARES DE TOMATE } \\
\hline & Carmem & Carmem & Débora & Débora \\
\hline & Convencional & Orgânico & Convencional & Orgânico \\
\hline Água (\%) & 94,53 & 94,53 & 94,21 & 93,73 \\
\hline Nitrogênio & 114,87 & 136,31 & 138,61 & 143,96 \\
\hline Fósforo & 20,24 & 23,36 & 17,37 & 21,88 \\
\hline Potássio* & 129,75 & 146,49 & 190,49 & 177,50 \\
\hline Cálcio & 9,03 & 6,02 & 8,40 & 6,27 \\
\hline Magnésio* & 7,06 & 8,53 & 7,64 & 8,03 \\
\hline Enxofre & 7,17 & 10,28 & 6,72 & 10,28 \\
\hline Sódio & 1,09 & 2,08 & 1,91 & 2,01 \\
\hline Boro & 0,11 & 0,06 & 0,08 & 0,13 \\
\hline Cobre & 0,33 & 0,07 & 0,26 & 0,05 \\
\hline Ferro & 0,30 & 0,44 & 0,29 & 0,37 \\
\hline Manganês & 0,08 & 0,06 & 0,17 & 0,09 \\
\hline Zinco & 0,16 & 0,19 & 0,12 & 0,15 \\
\hline
\end{tabular}

*O tomate é considerado alimento fonte dos nutrientes assinalados.

Para a discussão dos resultados apresentados na Tabela 4 adotou-se, como referência, os valores obtidos, tendo por base, frutos de tomate in natura de origem nacional, registrados na Tabela de Composição Nutricional de Hortaliças elaborada pela Embrapa Hortaliças (Luengo et al., 2000). A discussão em torno dos resultados, 
apresentada a seguir, baseia-se na quantidade identificada dos nutrientes obtidos a partir de análises de $100 \mathrm{~g}$ de frutos de tomate in natura (Tabela 4).

De acordo com a quantidade de água $(93,76 \%)$ registrada por Luengo et al. (2000), pode-se observar que o tomate Débora cultivado organicamente apresentou o teor mais próximo desse valor $(93,73 \%)$. Os demais apresentaram teores ligeiramente superiores, no entanto, muito semelhantes ao valor de referência.

O nitrogênio apresentou conteúdos similares nos tomates Carmem orgânico (136,31mg) e Débora convencional (138,61mg). Os frutos Débora orgânicos apresentaram 143,96mg, enquanto o menor conteúdo foi identificado no tomate Carmem convencional (114,87mg). Em pesquisa realizada por Havard \& Warman (1997) envolvendo cenouras, foi possível a identificação de conteúdo significativamente mais alto de $\mathrm{N}$, nas amostras cultivadas convencionalmente. Os conteúdos identificados nesta dissertação não confirmam essa tendência de superioridade para os frutos de tomate produzidos convencionalmente.

Os valores de fósforo (Tabela 4) para os quatro lotes analisados apresentaram-se inferiores ao valor (50mg) registrado por Luengo et al. (2000).

O potássio, de acordo com Luengo et al. (2000) é um mineral abundante no tomate, credenciando-o para ser reconhecido como alimento-fonte desse mineral. Foram obtidos teores de 129,75 e 146,49mg de potássio para o tomate Carmem convencional e orgânico, respectivamente, enquanto o cultivar Débora apresentou valores de 190,49mg para o cultivo convencional e 177,50mg para o orgânico. $O$ valor de referência encontrado para esse mineral foi de $222 \mathrm{mg}$, conteúdo do qual o tomate Débora convencional mais se aproximou, quando comparado aos demais.

Os conteúdos de cálcio observados na Tabela 4 se revelaram distintos, para os frutos cultivados pelo método orgânico e convencional. Utilizando-se o teor de cálcio de 5mg registrado por Luengo et al. (2000), como parâmetro, é possível destacar que os conteúdos obtidos para os tomates da produção orgânica $(6,02$ e 6,27mg) foram os que mais se aproximaram do valor de referência, enquanto as análises do alimento convencional mostraram conteúdos superiores $(9,03$ e $8,40 \mathrm{mg})$. Esse fato pode estar relacionado com as diferenças no manejo para os dois métodos de cultivo. 
De acordo com Luengo et al. (2000), o tomate in natura é considerado uma importante fonte de magnésio. Os valores de magnésio, obtidos na presente pesquisa, revelaram-se similares quando se considera os quatro tipos de frutos (valores abaixo do valor de referência adotado de $11 \mathrm{mg}$ ).

Para o enxofre, os conteúdos revelaram, diferenças para os distintos frutos analisados, especialmente no tocante ao método de cultivo. Os frutos produzidos organicamente apresentaram um conteúdo idêntico de 10,28mg, enquanto o convencional apresentou os valores 7,17 e 6,72mg, para o cultivar Carmem e Débora, respectivamente. Essa diferença pode estar relacionada à aplicação de Calda Bordalesa, insumo que o produtor declarou utilizar como defensivo para o cultivo do tomate orgânico. A "Calda Bordalesa" é um tradicional defensivo agrícola, obtido mediante a mistura de sulfato de cobre, cal hidratada e água. Atua contra doenças fúngicas e bacterianas. Segundo Penteado (2001), apesar de ser preparada com minerais químicos, esta "calda" é aceita pela agricultura orgânica devido ao fato de seus componentes integrarem os processos metabólicos das plantas, sendo nutrientes essenciais para a constituição das mesmas. Não foram encontrados, em publicações científicas, valores de referência para o conteúdo de enxofre em frutos de tomate.

Os conteúdos de sódio dos frutos analisados revelaram-se menores quando comparados ao valor de 9mg registrado por Luengo et al. (2000). Deve-se salientar que o tomate Carmem convencional revelou conteúdo de 1,1mg. O conteúdo pode ser considerado o menor, quando comparado aos demais.

Em pesquisa realizada por Havard \& Warman (1997), as cenouras cultivadas organicamente apresentaram maior conteúdo de boro. Tendo por base os teores apresentados na Tabela 4, não é possível verificar quantidade superior desse mineral, nos frutos produzidos organicamente. As referências científicas sobre o tema não revelam valores de referência para o conteúdo de boro em frutos de tomate.

Os conteúdos de cobre revelaram-se muito elevados para os frutos produzidos convencionalmente $(0,33$ e $0,26 \mathrm{mg})$, quando comparado com os valores obtidos por meio das análises dos frutos cultivados organicamente $(0,07$ e $0,05 \mathrm{mg})$ e também com o 
conteúdo $(0,07 \mathrm{mg})$ registrado por Luengo et al. (2000). Essa superioridade do conteúdo de cobre, pode ser um indicativo de que o manejo convencional promoveu a aplicação de fungicidas, contendo em sua formulação o cobre. Essa tendência pode ser confirmada pelos dados da pesquisa realizada por Havard \& Warman (1997) que obtiveram um conteúdo significativamente mais alto de cobre em cenouras cultivadas convencionalmente. Segundo Silva (1996), a resistência de plantas a doenças fúngicas está relacionada com o suprimento adequado de cobre. $\mathrm{O}$ referido autor avaliou os teores foliares de cobre em citros, decorrente da aplicação de fungicidas, e constatou que os lotes que receberam fungicida cúprico, aos 30 e 60 dias após aplicação, revelaram teores elevados de cobre (considerados níveis excessivos, pelo autor).

Quando se analisa o conteúdo de ferro, o maior valor $(0,44 \mathrm{mg})$ foi identificado por meio das análises do tomate Carmem orgânico, enquanto $0,37 \mathrm{mg}$ foi o conteúdo obtido para o Débora orgânico. No entanto, o teor de ferro do tomate Carmem convencional alcançou $0,30 \mathrm{mg}$ e no Débora convencional $0,29 \mathrm{mg}$. Vale frisar que o valor de referência adotado, nesta pesquisa, é $0,45 \mathrm{mg}$ de ferro.

No caso do manganês, o conteúdo registrado (Tabela 4) pelo tomate Débora convencional $(0,17 \mathrm{mg})$ encontra-se muito próximo ao valor de referência $(0,15 \mathrm{mg})$. No entanto, conteúdos menores e similares foram identificados para as demais amostras analisadas na presente pesquisa.

Para o zinco, os teores obtidos se revelaram superiores ao valor adotado como referência $(0,09 \mathrm{mg})$. O conteúdo apresentado pelo tomate Carmem orgânico $(0,19 \mathrm{mg})$, mostrado na Tabela 4, se revela elevado, quando comparado aos demais, enquanto que o menor conteúdo $(0,12 \mathrm{mg})$ foi obtido para o Débora convencional.

Tendo por base os resultados obtidos nesta pesquisa, não é possível afirmar que existam diferenças substanciais entre a composição nutricional dos frutos produzidos pelo método convencional e orgânico. Porém, chama a atenção a presença de um nutriente, como é o caso do cobre, se revelar em maior quantidade nas amostras dos frutos produzidos convencionalmente. Tendo em vista que, a presença do cobre em elevadas concentrações, é indesejada na dieta humana e que o seu conteúdo, em quantidades mais altas, em um alimento amplamente consumido, como é o caso do 
tomate, pode ser considerado um fator de risco à saúde do consumidor, o resultado merece atenção especial e novos estudos complementares deverão ser implementados, objetivando ampliar o rol de informações sobre o tema.

\subsection{Análise Sensorial}

Vale registrar que as tabelas contendo os dados referentes à opinião dos provadores, no tocante a avaliação de cada atributo, para os frutos de tomate in natura, encontram-se nos Anexos C, D, E e F. 
Tabela 5. Médias das notas conferidas pelos provadores aos atributos avaliados (aroma, sabor, cor e aspecto geral) dos frutos de tomate in natura dos cultivares Carmem e Débora produzidos pelo método de cultivo convencional e orgânico.

\begin{tabular}{|c|c|c|c|c|c|c|c|c|c|c|c|c|c|c|c|c|}
\hline & \multicolumn{16}{|c|}{ Cultivares de Tomate } \\
\hline & \multicolumn{4}{|c|}{ Carmem Convencional } & \multicolumn{4}{|c|}{ Carmem Orgânico } & \multicolumn{4}{|c|}{ Débora Convencional } & \multicolumn{4}{|c|}{ Débora Orgânico } \\
\hline & Aroma & Sabor & Cor & Geral & Aroma & Sabor & Cor & Geral & Aroma & Sabor & Cor & Geral & Aroma & Sabor & Cor & Geral \\
\hline Média & 7,8 & 7,7 & 7,5 & 7,2 & 7,3 & 6,7 & 7,7 & 8,1 & 7,9 & 8,1 & 7,9 & 7,8 & 7,7 & 6,9 & 7,5 & 7,6 \\
\hline $\begin{array}{l}\text { Desvio- } \\
\text { padrão }\end{array}$ & 1,4 & 1,3 & 1,6 & 1,4 & 1,7 & 2,0 & 1,5 & 1,1 & 1,2 & 1,4 & 1,5 & 1,3 & 1,5 & 1,9 & 1,7 & 1,6 \\
\hline Nota mínima & 3,0 & 4,0 & 2,0 & 3,0 & 3,0 & 1,0 & 3,0 & 5,0 & 4,0 & 2,0 & 3,0 & 4,0 & 4,0 & 2,0 & 3,0 & 3,0 \\
\hline Nota máxima & 9,0 & 9,0 & 9,0 & 9,0 & 9,0 & 9,0 & 9,0 & 9,0 & 9,0 & 9,0 & 9,0 & 9,0 & 9,0 & 9,0 & 9,0 & 9,0 \\
\hline
\end{tabular}


Os atributos avaliados, pelos provadores, na Análise Sensorial dos quatro tratamentos foram o aroma, o sabor, a cor e o aspecto geral.

$\mathrm{Na}$ Tabela 6, apresentada a seguir, é possível observar a comparação das médias das notas atribuídas pelos provadores aos quatro tratamentos.

Tabela 6. Comparação das médias das notas atribuídas pelos provadores aos quatro tratamentos.

\begin{tabular}{|c|c|c|c|c|}
\hline \multirow[b]{2}{*}{ Tratamentos } & \multicolumn{4}{|c|}{ Notas (médias) conferidas aos atributos } \\
\hline & Aroma & Sabor & Cor & Aspecto Geral \\
\hline Carmem & & & & \\
\hline convencional & $7,76^{\mathrm{A}}$ & $7,72^{\mathrm{AB}}$ & $7,52^{\mathrm{A}}$ & $7,23^{\mathrm{B}}$ \\
\hline Carmem & & & & \\
\hline orgânico & $7,30^{\mathrm{A}}$ & $6,67^{\mathrm{C}}$ & $7,70^{\mathrm{A}}$ & $8,06^{\mathrm{A}}$ \\
\hline Débora & & & & \\
\hline convencional & $7,94^{\mathrm{A}}$ & $8,06^{\mathrm{A}}$ & $7,91^{\mathrm{A}}$ & $7,79^{\mathrm{AB}}$ \\
\hline Débora & & & & \\
\hline orgânico & $7,68^{\mathrm{A}}$ & $6,91^{\mathrm{BC}}$ & $7,55^{\mathrm{A}}$ & $7,62^{\mathrm{AB}}$ \\
\hline
\end{tabular}

Nota: médias acompanhadas com a mesma letra não diferem significativamente ao nível de $5 \%$.

Os dados foram submetidos à análise estatística e constatou-se que apenas para os atributos de sabor e aspecto geral houve diferença significativa ao nível de 5\%, entre os tratamentos.

No que se refere ao aroma, a Tabela 6 mostra que não há diferença significativa entre as médias dos 4 tratamentos. As notas atribuídas ao aroma indicam que os provadores gostaram de forma regular a moderada desse atributo dos frutos de tomate in natura.

Com relação à avaliação subjetiva do sabor, o tomate Carmem produzido organicamente recebeu nota média $(6,67)$ menor do que aquela atribuída ao tomate cultivado convencionalmente $(7,72)$. Pode-se constatar que a diferença é estatisticamente 
significativa ao nível de 5\%. O cultivar Débora obtido por meio do cultivo convencional obteve nota $(8,06)$ maior do que a obtida pelo cultivo orgânico $(6,91)$, verifica-se que a diferença também é estatisticamente significativa ao nível de 5\%.

De acordo com os resultados das análises físico-químicas, apresentados anteriormente, tanto no caso do cultivar Carmem como no caso do cultivar Débora, a razão entre graus Brix e a acidez total titulável foi maior para os tomates cultivados convencionalmente do que para os "orgânicos", o que indica uma menor acidez dos tomates "convencionais".

A atribuição, pelos provadores, de maior nota referente ao sabor dos frutos com menor acidez, parece atestar que houve uma percepção dos provadores, com relação à acidez. Tal fato comprova a tendência, de preferência por alimentos pouco ácidos, observada no comportamento do consumidor brasileiro.

Quando se observa o atributo cor (Tabela 6), os dados indicam que os tratamentos não diferiram estatisticamente entre si. As notas atribuídas pelos provadores revelaram que os mesmos gostaram da cor dos frutos de maneira que varia de regular a moderada.

Em relação ao aspecto geral, os dados da Tabela 6 revelam que houve diferença significativa entre os frutos Carmem cultivados convencionalmente e organicamente. A maior nota $(8,06)$ foi atribuída ao tomate Carmem produzido organicamente. Os frutos do cultivar Débora cultivados organicamente e convencionalmente não diferiram estatisticamente entre si, ao nível de $5 \%$.

\subsection{Caracterização dos participantes da pesquisa: aspectos socioeconômicos, estilo de vida e atitudes relativas à aquisição e consumo de alimentos}

A seguir, serão mostrados os resultados obtidos junto à amostra $(n=59)$ dos

voluntários integrantes da pesquisa, que também participaram da Análise Sensorial. Inicialmente são apresentadas (Tabelas 7, 8, 9 e 10) as informações gerais, que possibilitam a melhor caracterização do grupamento analisado. 
Tabela 7. Distribuição dos entrevistados de acordo com o gênero. Piracicaba, 2002.

\begin{tabular}{lcc}
\hline Gênero & \multicolumn{2}{c}{ Freqüência } \\
\cline { 2 - 3 } & Número & Percentual \\
Masculino & 15 & 25,4 \\
Feminino & 44 & 74,6 \\
TOTAL & 59 & 100,0 \\
\hline
\end{tabular}

Tabela 8. Distribuição dos entrevistados de acordo com o nível de escolaridade. Piracicaba, 2002.

\begin{tabular}{lcc}
\hline Nível de Escolaridade & \multicolumn{2}{c}{ Freqüência } \\
\cline { 2 - 3 } 1 grau incompleto & Número & Percentual \\
1 grau completo & 3 & 5,1 \\
2 grau incompleto & 3 & 5,1 \\
2 grau completo & 2 & 3,4 \\
3 grau (nível universitário) & 26 & 44,1 \\
Pós-graduação & 15 & 25,4 \\
TOTAL & 10 & 16,9 \\
\hline
\end{tabular}

Em uma breve análise dos resultados, tendo por base os dados mostrados nas Tabelas 7 e 8, verifica-se que a maioria dos participantes da pesquisa eram mulheres, $86,4 \%$ dos participantes tinham completado o $2^{\circ}$ grau, sendo que entre eles, 42,3\% possuíam curso universitário. No tocante a esses aspectos a amostra revela similaridade com a descrita por Govindasamy \& Itália (1999), tendo por base dados da pesquisa 
realizada em vários estabelecimentos comerciais de Nova Jersey, visando conhecer as opiniões dos consumidores sobre os produtos orgânicos. Os autores verificaram que aproximadamente $66 \%$ dos participantes eram mulheres e $83 \%$ tinham, pelo menos, o $2^{\circ}$ grau (ou equivalente) completo.

Tabela 9. Distribuição dos entrevistados de acordo com o estrato de renda mensal familiar (em salários mínimos). Piracicaba, 2002.

\begin{tabular}{ccc}
\hline $\begin{array}{l}\text { Estratos de renda mensal } \\
\text { familiar (em salários }\end{array}$ & \multicolumn{3}{c}{ Freqüência } \\
mínimos) & Número & Percentual \\
\cline { 2 - 3 } 1 & 6 & 10,2 \\
1 a 2 & 3 & 5,1 \\
3 a 6 & 5 & 8,5 \\
7 a 10 & 16 & 27,1 \\
11 a 15 & 10 & 16,9 \\
16 a 30 & 11 & 18,6 \\
30 & 8 & 13,6 \\
TOTAL & 59 & 100,0 \\
\hline
\end{tabular}

De acordo com os dados da Tabela 9, verifica-se que houve predomínio $(35,5 \%)$ de participantes cuja renda mensal familiar situava-se entre os valores de 11 a 30 salários mínimos e 27,1\% de voluntários com rendimentos entre 7 a 10 salários mínimos. Nota-se, portanto, uma proporção majoritária de participantes da pesquisa com rendimentos que podem ser classificados como elevados, tendo como referência a renda média da população brasileira. 
Tabela 10. Distribuição dos entrevistados de acordo com o número de pessoas que integram a família. Piracicaba, 2002.

\begin{tabular}{lccc}
\hline Número de pessoas na & \multicolumn{2}{c}{ Freqüência } \\
família & 1 & 2 & Percentual \\
\cline { 3 - 4 } 2 & 13 & 3,4 \\
3 & 11 & 22,0 \\
4 & 15 & 18,6 \\
5 & 11 & 25,4 \\
6 & 2 & 18,6 \\
7 & 2 & 3,4 \\
Não respondeu & 3 & 3,4 \\
TOTAL & 59 & 5,2 \\
\hline
\end{tabular}

Ao examinar os dados da Tabela 10, verifica-se que há predomínio de famílias pouco numerosas. Note-se que praticamente metade dos participantes (44\%) pertencem a famílias compostas por 4 a 5 membros e 40,6\% integram famílias compostas por 2 a 3 membros.

Tendo em vista a importância de conhecer o estilo de vida dos integrantes da amostra, especialmente no que tange aos hábitos/consumo de alimentos, apresenta-se a seguir os principais resultados. 
Tabela 11. Distribuição dos entrevistados de acordo com o tempo de incorporação de novos hábitos alimentares ao estilo de vida. Piracicaba, 2002.

\begin{tabular}{ccc}
\hline Tempo (em meses) & \multicolumn{3}{c}{ Freqüência } \\
\cline { 2 - 3 }$<6$ & Número & Percentual \\
12 a 24 & 6 & 33,4 \\
28 a 84 & 3 & 16,7 \\
$>120$ & 4 & 22,2 \\
Não informou & 4 & 22,2 \\
TOTAL & 1 & 5,5 \\
\hline
\end{tabular}

Nota: cálculos elaborados tendo por base o número $(n=18)$ de informações válidas, obtidas junto aos entrevistados que alegaram a incorporação de novos hábitos alimentares.

De acordo com os dados apresentados na Tabela 11, observa-se que 18 indivíduos, que representam $30,3 \%$ da amostra $(n=59)$ fizeram referência à incorporação de novos hábitos alimentares. Entretanto, desse número $(n=18)$ de indivíduos, 33,4\% tiveram a iniciativa há menos de 6 meses (tendo por base o mês de obtenção dos dados, abril/2002) e praticamente a metade (44,4\%), incorporaram os novos hábitos, no mínimo há 24 meses (o período citado variou entre 28 e 120 meses). 
Tabela 12. Distribuição dos entrevistados de acordo com as citações referentes à adoção de práticas alimentares “alternativas”. Piracicaba, 2002.

\begin{tabular}{lcc}
\hline Práticas alimentares & \multicolumn{2}{c}{ Freqüência } \\
\cline { 2 - 3 } & Número & Percentual \\
Vegetariana & 2 & 10,0 \\
Naturalista & 7 & 35,0 \\
Descrição de dieta especial & 10 & 50,0 \\
Dietas motivadas pela & 1 & 5,0 \\
religião & & 100,0 \\
$\quad$ TOTAL & 20 & \\
\hline
\end{tabular}

A Tabela 12 apresenta a distribuição dos indivíduos que registraram terem alterado o estilo de vida, incorporando práticas alimentares consideradas "alternativas". Nesse caso, $50 \%$ citaram a adoção da dieta especial na qual pode-se $\operatorname{listar}^{2}$ desde a restrição ao consumo de determinados alimentos como, por exemplo, carne vermelha e café. Também foi citada a incorporação, com relativo destaque, do consumo de outros alimentos como, por exemplo, frutas, hortaliças e alimentos light. A dieta definida como naturalista foi citada por $35 \%$ dos participantes da pesquisa que declararam terem adotado algum hábito alimentar diferenciado. Dietas motivadas pela religião e a dieta vegetariana foram citadas, porém com menor frequiência.

Pesquisa realizada por Assis et al. (1995), envolvendo consumidores de feiras de produtos orgânicos do estado do Rio de Janeiro, revelou que a diferença observada no hábito alimentar dos consumidores desses produtos, decorre, principalmente em função da diferenciação do próprio alimento orgânico em relação ao alimento convencional e, na maioria dos casos, a opção pelo orgânico, não apresenta como motivação a adoção de práticas alimentares específicas.

\footnotetext{
${ }^{2}$ tabela não apresentada nesta seção do trabalho.
} 
Vale lembrar que na presente pesquisa, especial ênfase foi dada ao tomate. Visando atender os objetivos da pesquisa, apresenta-se a seguir os resultados envolvendo o referido alimento (Tabelas 13, 14, 15, 16 e 17).

Tabela 13. Distribuição dos entrevistados de acordo com as citações referentes aos atributos considerados durante a compra de tomate. Piracicaba, 2002.

\begin{tabular}{|c|c|c|}
\hline \multirow[t]{2}{*}{ Atributos } & \multicolumn{2}{|c|}{ Freqüência } \\
\hline & Número & Percentual \\
\hline Aparência & 46 & 42,2 \\
\hline $\begin{array}{l}\text { Características que indicam maior } \\
\text { probabilidade de durabilidade }\end{array}$ & 25 & 22,9 \\
\hline Sabor/aroma & 12 & 11,0 \\
\hline $\begin{array}{l}\text { Garantia (existência de } \\
\text { informação) que não tem resíduo }\end{array}$ & 10 & 9,2 \\
\hline Preço (opção pelo menor preço) & 9 & 8,3 \\
\hline Informações relativas ao conteúdo & 7 & 6,4 \\
\hline TOTAL & 109 & 100,0 \\
\hline
\end{tabular}

Nota: questão contendo várias opções para registro das respostas (múltipla escolha).

Com relação aos atributos considerados durante a compra de tomate, os resultados apresentados na Tabela 13, mostram que a aparência foi o item que recebeu maior número de citações, correspondendo a 42,2\% do total $(n=109)$. Vale destacar que $22,9 \%$ e $11,0 \%$ das citações recaíram para os atributos "características que indicam maior probabilidade de durabilidade" e sabor/aroma, respectivamente. Note-se que 9,2\% das citações referem-se à garantia de que o tomate não tem resíduo tóxico que poderia prejudicar o organismo humano. No entanto, é importante lembrar que se trata de uma condição praticamente impossível de ser confirmada, durante o processo de compra. Os 
tomates cultivados convencionalmente, colocados à venda, em sua maioria não registram esse tipo de informação. Além do mais, invariavelmente os resíduos são substâncias dificilmente identificáveis, sem a utilização de recursos especiais. Informações relativas ao conteúdo nutricional foram citadas por apenas $6,4 \%$ dos indivíduos. Vale citar que Chitarra (1994) se refere ao valor nutritivo dos frutos como sendo o atributo de qualidade menos considerado pelos produtores e consumidores desses alimentos.

Tabela 14. Distribuição dos entrevistados de acordo com a frequiência de consumo de tomate. Piracicaba, 2002.

\begin{tabular}{lcc}
\hline Freqüência de consumo & \multicolumn{2}{c}{ Freqüência } \\
\cline { 2 - 3 } & Número & Percentual \\
Diariamente & 38 & 64,4 \\
Semanalmente & 18 & 30,5 \\
Eventualmente & 3 & 5,1 \\
Raramente & - & - \\
Nunca & - & - \\
TOTAL & 59 & 100,0 \\
\hline
\end{tabular}

Nota: os traços significam que não foram observadas citações para a frequiência.

A maioria dos entrevistados $(64,4 \%)$ registrou que consome tomate diariamente, enquanto 30,5\% disseram que adotam essa prática, semanalmente e apenas 5,1\% dos participantes eventualmente ingerem o alimento. A elevada freqüiência de consumo de tomate entre os participantes da presente pesquisa, confirma os dados da Pesquisa de Orçamentos Familiares de 1995 - 1996 (Instituto, 1998), que atribuem destaque ao tomate como a hortaliça frutosa (de acordo com a apresentação do IBGE), mais consumida pela população integrante da POF. 
Foi solicitado aos participantes da pesquisa que informassem a ocorrência de mudança (nos últimos meses) na dieta, no tocante ao aumento de consumo de tomate, motivada por prévias orientações de profissionais ou outros tipos de informações.

A maioria (84,7\%) dos entrevistados registrou que não incorporou qualquer mudança na dieta habitual, visando assegurar uma maior participação do tomate. Situação inversa foi relatada por cerca de $15 \%$ dos entrevistados.

A seguir é mostrada a Tabela 15 contendo os resultados referentes à origem ou fonte da orientação que, parcela (cerca de 15\%) dos participantes registrou, obtendo como consequiência um aumento da quantidade de tomate consumida.

Tabela 15. Distribuição das citações registradas pelos entrevistados, relativas a fonte de informação que motivou o aumento de consumo de tomate. Piracicaba, 2002.

\begin{tabular}{|c|c|c|c|c|}
\hline \multirow[t]{3}{*}{ Fonte da informação } & \multicolumn{4}{|c|}{ Freqüência de citações } \\
\hline & \multicolumn{2}{|c|}{$\operatorname{sim}$} & \multicolumn{2}{|c|}{ não } \\
\hline & $\mathrm{n}$ & $\%$ & $\mathrm{n}$ & $\%$ \\
\hline Médico & - & - & 59 & 100,0 \\
\hline Nutricionista & 2 & 3,4 & 57 & 96,6 \\
\hline Farmacêutico & - & - & 59 & 100,0 \\
\hline Amigos/parentes & 1 & 1,7 & 58 & 98,3 \\
\hline Reportagem em revista & 3 & 5,1 & 56 & 94,9 \\
\hline Informação em jornal & 2 & 3,4 & 57 & 96,6 \\
\hline Televisão & 3 & 3,4 & 57 & 96,6 \\
\hline
\end{tabular}

Nota: questão com possibilidade de registro de resposta múltipla.

Ao examinar os dados da Tabela 15 é possível verificar que há um predomínio de citações que atribuem às reportagens (revistas) e à televisão, as fontes de informações que motivaram o aumento da participação do tomate na dieta. $\mathrm{O}$ consumo de tomate tem sido recomendado, motivado principalmente, em decorrência de resultados de pesquisas 
que revelam, em sua composição, a presença de substâncias que podem exercer um papel preventivo contra algumas doenças crônicas. O tomate possui, de forma geral, substancial quantidade de licopeno (Stahl \& Sies, 1996). Minami \& Haag (1989) fazem referência ao seu baixo valor energético que o torna recomendável para indivíduos que desejam submeter-se a dietas hipocalóricas ou que necessitam de um alimento de fácil digestão. O fruto in natura é classificado como alimento fonte de vitamina C.

Tabela 16. Distribuição dos entrevistados, de acordo com estratos de renda familiar (em salários mínimos) e freqüência de consumo de tomate. Piracicaba, 2002.

\begin{tabular}{|c|c|c|c|c|c|c|c|c|}
\hline Estratos de & & & & & & & & \\
\hline Renda & Entrev & ados & & & qüência & e Cons & & \\
\hline calários & & & Diari & nente & Seman & mente & Event & ente \\
\hline mínimos) & $\mathrm{n}^{\circ}$ & $\%$ & $\mathrm{~N}^{\circ}$ & $\%$ & $\mathrm{n}^{\circ}$ & $\%$ & $\mathrm{n}^{\circ}$ & $\%$ \\
\hline$<1$ & 6 & 10,2 & 3 & 50,0 & 2 & 33,3 & 1 & 6,7 \\
\hline 1 a 2 & 3 & 5,1 & 1 & 33,3 & 2 & 66,7 & 0 & 0,0 \\
\hline 3 a 6 & 5 & 8,5 & 3 & 60,0 & 2 & 40,0 & 0 & 0,0 \\
\hline 7 a 10 & 16 & 27,1 & 12 & 75,0 & 3 & 18,8 & 1 & 6,2 \\
\hline 11 a 15 & 10 & 16,9 & 8 & 80,0 & 2 & 20,0 & 0 & 0,0 \\
\hline 16 a 30 & 11 & 18,6 & 7 & 63,6 & 4 & 36,4 & 0 & 0,0 \\
\hline 30 & 8 & 13,6 & 4 & 50,0 & 3 & 37,5 & 1 & 12,5 \\
\hline TOTAL & 59 & 100,0 & 38 & 64,4 & 18 & 30,5 & 3 & 5,1 \\
\hline
\end{tabular}

$\chi^{2}=8,33$ com 12 graus de liberdade não-significativo.

Tendo por base os dados da Tabela 16 verifica-se que, com exceção dos integrantes do grupamento com rendimentos entre um e dois salários mínimos, a totalidade dos participantes (com registro de consumo diário), pertencentes aos demais 
estratos de renda foi superior a 50\%. Note-se que para os estratos de renda familiar entre 7 a 10 e 11 a 15 salários mínimos, a frequiência de citações de consumo diária é de $75 \%$ e $80 \%$, respectivamente. Conforme descrito anteriormente, os dados da Pesquisa de Orçamentos Familiares (POF) de 1995 - 1996 (Instituto, 1998) demonstraram tendência similar, isto é, o consumo de tomate cresce à medida que aumenta a renda da população. De acordo com o Instituto (1998), a menor frequiência de consumo foi verificada entre as famílias com rendimentos entre 1 e 2 salários mínimos mensais.

Tabela 17. Distribuição dos entrevistados, de acordo com o nível de escolaridade e frequiência de consumo de tomate. Piracicaba, 2002.

\begin{tabular}{|c|c|c|c|c|c|c|c|c|}
\hline \multirow{3}{*}{$\begin{array}{l}\text { Nível de } \\
\text { Escolaridade }\end{array}$} & \multicolumn{2}{|c|}{ Entrevistados } & \multicolumn{6}{|c|}{ Frequiência de consumo } \\
\hline & \multirow{2}{*}{$\mathrm{n}$} & \multirow{2}{*}{$\%$} & \multicolumn{2}{|c|}{ Diariamente } & \multicolumn{2}{|c|}{ Semanalmente } & \multicolumn{2}{|c|}{ Eventualmente } \\
\hline & & & $\mathrm{n}$ & $\%$ & $\mathrm{n}$ & $\%$ & $\mathrm{n}$ & $\%$ \\
\hline 1 grau & & & & & & & & \\
\hline incompleto & 3 & 5,1 & 2 & 66,7 & 1 & 3,3 & 0 & 0,0 \\
\hline 1 grau & & & & & & & & \\
\hline completo & 3 & 5,1 & 2 & 66,7 & 1 & 33,3 & 0 & 0,0 \\
\hline 2 grau & & & & & & & & \\
\hline incompleto & 2 & 3,4 & 0 & 0,0 & 2 & 100,0 & 0 & 0,0 \\
\hline 2 grau & & & & & & & & \\
\hline completo & 26 & 44,1 & 19 & 73,1 & 7 & 26,9 & 0 & 0,0 \\
\hline 3 grau (nível & & & & & & & & \\
\hline universitário) & 15 & 25,4 & 10 & 66,7 & 4 & 26,7 & 1 & 6,6 \\
\hline Pós- & & & & & & & & \\
\hline graduação & 10 & 16,9 & 5 & 50,0 & 3 & 30,0 & 2 & 20,0 \\
\hline TOTAL & 59 & 100,0 & 38 & 64,4 & 18 & 30,5 & 3 & 5,1 \\
\hline
\end{tabular}

$\chi^{2}=11,47$, com 10 graus de liberdade não-significativo. 
Quando se considera a relação entre a freqüência de consumo de tomate e o nível de escolaridade, observa-se (Tabela 17) uma maior freqüência de consumo diário entre os indivíduos que possuem o $2^{\circ}$ grau completo $(73,1 \%)$, enquanto que os indivíduos que não completaram o $2^{\circ}$ grau apresentaram $100 \%$ de freqüência de consumo semanal. Nesta pesquisa, não foi possível verificar associação, estatisticamente significativa, entre as variáveis escolaridade e frequiência de consumo de tomate.

Tabela 18. Distribuição dos entrevistados, de acordo com o costume de comprar e consumir alimentos orgânicos. Piracicaba, 2002.

\begin{tabular}{lccc}
\hline \multicolumn{2}{l}{$\begin{array}{l}\text { Costume de comprar e } \\
\text { consumir alimentos }\end{array}$} & Número & Freqüência \\
\cline { 3 - 4 } orgânicos & & Percentual \\
\cline { 3 - 4 } & Sim & 31 & 52,5 \\
Não & 28 & 47,5 \\
TOTAL & 59 & 100,0 \\
\hline
\end{tabular}

Ao examinar os dados da Tabela 18 é possível verificar que a maioria dos entrevistados $(52,5 \%)$ revelou que tem o costume de adquirir alimentos orgânicos. 
Tabela 19. Distribuição dos entrevistados, de acordo com a freqüência de consumo de alimentos orgânicos. Piracicaba, 2002.

\begin{tabular}{lcc}
\hline Freqüência de consumo & \multicolumn{2}{c}{ Freqüência } \\
\cline { 2 - 3 } & Número & Percentual \\
Diariamente & 8 & 25,8 \\
Semanalmente & 10 & 32,3 \\
Eventualmente & 12 & 38,7 \\
Raramente & 1 & 3,2 \\
TOTAL & 31 & 100,0 \\
\hline
\end{tabular}

Nota: cálculos elaborados tendo por base o número $(n=31)$ de informações válidas.

Tendo por base os dados da Tabela 19 observa-se que há predomínio de citações referentes ao consumo eventual $(39,7 \%)$ e semanal $(32,3 \%)$ de alimentos orgânicos. Ao examinar a proporção de consumidores que, nesta pesquisa, informaram consumir diariamente algum tipo de produto orgânico, nota-se que os resultados são praticamente iguais aos dados obtidos por Penteado (2000). O referido autor registrou que 25\% dos consumidores norte-americanos compravam alimentos orgânicos, pelo menos uma vez por semana. Tal resultado possivelmente decorre do fato de substancial parcela da amostra possuir bom nível de escolaridade e, também, de rendimentos. 
Tabela 20. Distribuição das citações referentes aos tipos de alimentos orgânicos adquiridos e consumidos pelos entrevistados. Piracicaba, 2002.

\begin{tabular}{|c|c|c|}
\hline \multirow[t]{2}{*}{ Tipos } & \multicolumn{2}{|c|}{ Freqüuência } \\
\hline & Número & Percentual \\
\hline Hortaliças & 27 & 45,8 \\
\hline Frutas & 13 & 22,0 \\
\hline Carnes & 5 & 8,5 \\
\hline Ovos & 5 & 8,5 \\
\hline Cereais & 4 & 6,8 \\
\hline Laticínios & 4 & 6,8 \\
\hline Alimentos prontos para & 1 & 1,6 \\
\hline consumo & & \\
\hline TOTAL & 59 & 100,0 \\
\hline
\end{tabular}

Nota: os cálculos foram daborados tendo por base o número $(n=59)$ de citações registradas pelos entrevistados. Vale informar que a questão possibilitava o registro de uma opção ou mais de resposta(s).

Ao analisar os tipos de alimentos orgânicos consumidos (Tabela 20) observa-se que houve predominância de citação referente as hortaliças (praticamente a metade das citações), ou seja 45,8\% do total. Os participantes fizeram referência às frutas (22\%), ocupando o segundo lugar na classificação. Em seguida aparecem as carnes, ovos, cereais, laticínios e, apenas uma citação para alimentos prontos para consumo. Segundo Ormond et al. (2002), a produção de hortaliças orgânicas no Brasil envolve um número substancial de produtores. Esse fato pode explicar a destacada presença e maior diversidade de hortaliças, quando se compara com o volume dos demais alimentos disponíveis no mercado nacional de produtos orgânicos. 
Tabela 21. Distribuição das citações registradas pelos entrevistados, relativas aos tipos de alimentos orgânicos consumidos. Piracicaba, 2002.

\begin{tabular}{|c|c|c|}
\hline \multirow{2}{*}{$\begin{array}{c}\text { Tipos de Alimentos } \\
\text { Orgânicos }\end{array}$} & \multicolumn{2}{|c|}{ Freqüiência } \\
\hline & Número & Percentual \\
\hline & 18 & 26,5 \\
\hline Alface & & \\
\hline Rúcula & 11 & 16,2 \\
\hline Tomate & 8 & 11,8 \\
\hline Agrião & 7 & 10,2 \\
\hline Cenoura & 4 & 5,9 \\
\hline Couve & 4 & 5,9 \\
\hline Chicória/escarola & 4 & 5,9 \\
\hline Brócolis & 2 & 2,8 \\
\hline Batata & 2 & 2,8 \\
\hline Cebola & 1 & 1,5 \\
\hline Acelga & 1 & 1,5 \\
\hline Rabanete & 1 & 1,5 \\
\hline Cheiro-verde & 1 & 1,5 \\
\hline Temperos & 1 & 1,5 \\
\hline Almeirão & 1 & 1,5 \\
\hline Folhas em geral & 1 & 1,5 \\
\hline Açúcar & 1 & 1,5 \\
\hline TOTAL & 68 & 100,0 \\
\hline
\end{tabular}


De acordo com os dados da Tabela 21, entre o grupo de hortaliças orgânicas mais citadas pelos consumidores, nota-se que o tomate ocupa a $3^{\text {a }}$ posição, enquanto hortaliças folhosas como alface $(26,5 \%)$ e rúcula $(16,2 \%)$ foram citadas com maior frequiência.

Tabela 22. Distribuição das citações dos entrevistados, referentes aos locais de compra dos alimentos orgânicos. Piracicaba, 2002.

Locais de compra

\begin{tabular}{lcc}
\cline { 2 - 3 } & Número & Percentual \\
Supermercado & 21 & 46,7 \\
Quitanda ou varejão & 8 & 17,8 \\
Feira comum & 7 & 15,6 \\
Feira de produtos orgânicos & 5 & 11,1 \\
Outros & 2 & 4,4 \\
Loja de produtos naturais & 1 & 2,2 \\
Entrega domiciliar & 1 & 2,2 \\
TOTAL & 45 & 100,0 \\
\hline
\end{tabular}

Nota: os cálculos foram elaborados tendo por base o número $(n=45)$ de citações registradas pelos entrevistados. Note-se que a questão possibilitava o registro de uma ou mais opção(ções) de resposta(s).

Os resultados referentes aos locais de compra de alimentos orgânicos, revelam que a maior freqüência de citações recai para o supermercado (46,7\%). Estabelecimentos como a quitanda ou o varejão foram citados por $17,8 \%$ dos consumidores, seguidos pela feira comum $(15,6 \%)$. A feira de produtos orgânicos foi citada por apenas $11,1 \%$ dos consumidores. Esses resultados confirmam a tendência de comercialização desses produtos em grandes redes de supermercado, de acordo com observações de Penteado 
(2000). De acordo com o referido autor, $42 \%$ das maiores redes de supermercados americanos comercializam alimentos cultivados organicamente. Realidade distinta foi descrita por Ormond et al. (2002), que revelaram que na Europa, 60\% dos produtos orgânicos são comercializados em lojas especializadas, 20\% em supermercados e $20 \%$ vendidos em feiras, locais alternativos, entregas domiciliares, entre outras.

Tabela 23. Distribuição dos entrevistados de acordo com os estratos de renda mensal familiar (em salários mínimos) e a freqüência de consumo de alimentos orgânicos. Piracicaba, 2002.

\begin{tabular}{|c|c|c|c|c|c|c|c|c|c|c|}
\hline \multirow{3}{*}{$\begin{array}{l}\text { Estratos de } \\
\text { renda } \\
\text { (em salários } \\
\text { mínimos) }\end{array}$} & \multirow{2}{*}{\multicolumn{2}{|c|}{ Total }} & \multicolumn{8}{|c|}{ Freqüência de consumo } \\
\hline & & & \multicolumn{2}{|c|}{ Diariamente } & \multicolumn{2}{|c|}{ Semanalmente } & \multicolumn{2}{|c|}{ Eventualmente } & \multicolumn{2}{|c|}{ Raramente } \\
\hline & $\mathrm{n}^{\circ}$ & $\%$ & $\mathrm{n}^{\circ}$ & $\%$ & $\mathrm{n}^{\circ}$ & $\%$ & $\mathrm{n}^{\circ}$ & $\%$ & $\mathrm{n}^{\circ}$ & $\%$ \\
\hline$<1$ & 5 & 16,1 & 1 & 20,0 & 3 & 60,0 & - & - & 1 & 20,0 \\
\hline 1 a 2 & 0 & 0,0 & - & - & - & - & - & - & - & - \\
\hline 3 a 6 & 1 & 3,2 & 1 & 100,0 & - & - & - & - & - & - \\
\hline 7 a 10 & 10 & 32,3 & 2 & 20,0 & 4 & 40,0 & 4 & 40,0 & - & - \\
\hline 11 a 15 & 4 & 12,9 & - & - & - & - & 4 & 100,0 & - & - \\
\hline 16 a 30 & 7 & 22,6 & 3 & 42,8 & 2 & 28,6 & 2 & 28,6 & _- & - \\
\hline 30 & 4 & 12,9 & 1 & 25,0 & 1 & 25,0 & 2 & 50,0 & - & - \\
\hline TOTAL & 31 & 100,0 & 8 & 25,0 & 10 & 32,3 & 12 & 38,7 & 1 & 3,2 \\
\hline
\end{tabular}

$\chi^{2}=43,59$, com 28 graus de liberdade, significativo a $10 \%$.

Nota: - Os traços significam que não foram registradas informações para a situação analisada.

- Análises elaboradas tendo por base o número $(n=31)$ de entrevistados que declararam consumir alimentos orgânicos.

Quando se analisou a frequiência de consumo de alimentos orgânicos, pelos entrevistados, conforme os estratos de renda mensal familiar, verificou-se, de forma muito nítida, que a maior frequêencia de consumo (diário e semanal) é observada entre o grupamento com renda entre 16 a 30 salários mínimos. É interessante notar, ainda, que mesmo entre o grupo de maior renda ( 30 salários mínimos) $50 \%$ consome 
eventualmente os alimentos orgânicos. Quando se examina o teste de qui-quadrado observa-se que há entre as variáveis analisadas, renda e consumo de alimentos orgânicos, associação estatisticamente significativa, ao nível de 10\%. Segundo Govindasamy \& Itália (1999), gênero e renda estão entre os determinantes mais significativos associados à compra dos produtos orgânicos. As famílias com rendimentos superiores têm um maior grau de confiança ra segurança do abastecimento de alimentos, entretanto, esse grupamento freqüentemente faz uso dos seus recursos financeiros para comprar alimentos que acreditam serem mais seguros ou de melhor qualidade.

Tabela 24. Distribuição das citações relativas ao conceito de alimentos orgânicos, registrados pelos entrevistados. Piracicaba, 2002.

\section{Conceito}

Freqüência de citações n

46

Sem agrotóxicos, defensivos, agroquímicos, insumos químicos ou resíduos químicos

Relacionado a benefícios à saúde

Alimentos naturais, uso de técnicas naturais, adubos de fontes naturais ou orgânicos (não industrializados)

Obedecem a critérios de produção

Não são geneticamente modificados, alimentos diferenciados e de qualidade superior

\section{Percentual}

$$
63,0
$$

Nota: os cálculos foram elaborados tendo por base o número $(n=73)$ de citações registradas pelos entrevistados. Note-se (Formulário, apresentado no Anexo 1) que se trata de questão, do tipo dissertativa, apresentada aos participantes. 
Quando os participantes da pesquisa foram questionados sobre a definição que adotavam para produtos ou alimentos orgânicos, 63\% referiram-se ao alimento como "sem agrotóxico". Assis et al. (1995) obtiveram semelhante percentual (60\%), entre os entrevistados selecionados em feira de produtos orgânicos no estado do Rio de Janeiro. Segundo Cerveira \& Castro (1999) essa afirmação é decorrente de informações veiculadas pela maioria dos meios de comunicação, que enfatizam a referida característica do produto orgânico.

Em pesquisa realizada por Govindasamy \& Itália (1999), a definição característica registrada pelos consumidores americanos, para a agricultura orgânica refere-se à ausência de pesticidas químicos sintéticos. Esse atributo reflete a forte aversão que a maioria dos referidos consumidores tem demonstrado ao risco representado pela possível presença de resíduos de pesticidas em alimentos, cultivados de forma convencional.

Os conceitos relacionados a benefícios à saúde ocupam o $2^{\circ}$ lugar com $15,1 \%$ das citações, como mostra a Tabela 24. Esse conceito foi registrado por $12 \%$ dos participantes da pesquisa de Cerveira \& Castro (1999).

Ainda de acordo com os resultados apresentados na Tabela 24, entre os conceitos citados, $11 \%$ referem-se aos produtos orgânicos como alimentos naturais e/ou obtidos com uso de técnicas e insumos naturais. Cerveira \& Castro (1999), analisando respostas obtidas entre população da cidade de São Paulo, verificaram que $15 \%$ das citações referiram-se aos produtos orgânicos como sendo naturais. Referência aos critérios de produção integrou $6,8 \%$ das citações, o que foi superior aos $2 \%$ de citações obtidas pelos referidos autores para esse aspecto da produção orgânica.

Verifica-se que 4,1\% das citações referem-se aos produtos orgânicos como sendo aqueles que não são geneticamente modificados, que são diferenciados e que apresentam qualidade superior. Cabe lembrar que entre os resultados da pesquisa realizada por Assis et al. (1995), 29\% das citações referiram-se a qualidade do alimento. 
Tabela 25. Distribuição das citações dos entrevistados, de acordo com as fontes consultadas para a conceituação de alimentos orgânicos. Piracicaba, 2002.

\begin{tabular}{lcc}
\hline Fontes consultadas & \multicolumn{2}{c}{ Frequiência } \\
\cline { 2 - 3 } Televisão & Número & Percentual \\
Revistas & 29 & 22,5 \\
Sala de aula & 26 & 20,2 \\
Livros & 20 & 15,5 \\
Jornal & 17 & 13,2 \\
Amigo/parente & 17 & 13,2 \\
Outros & 7 & 5,4 \\
Internet & 6 & 4,7 \\
Médico & 5 & 3,8 \\
TOTAL & 2 & 1,5 \\
\hline
\end{tabular}

Nota: cálculos elaborados tendo por base o número $(n=129)$ total de citações registradas. Note-se que a questão possibilitava o registro de uma ou mais opção(ções) de resposta(s).

Ao responderem sobre as fontes consultadas para a conceituação de alimentos ou produtos orgânicos, os participantes da pesquisa registraram maior frequiência de citações para a televisão (22,5\%), seguindo em ordem decrescente as citações para revistas, sala de aula, livros, jornais, entre outros, citados com menor frequiência. Esses resultados confirmam a importância dos especialistas e dos meios de comunicação como fonte de informação esclarecedora sobre o conceito dos produtos orgânicos e também para orientar potenciais consumidores em direção a um maior consumo, mais conscientes sobre as reais características do alimento a ser adquirido e consumido. 
Tabela 26. Distribuição das citações dos entrevistados de acordo com as motivações para comprar e consumir alimentos orgânicos. Piracicaba, 2002.

\begin{tabular}{lcc}
\hline Motivações para compra & \multicolumn{2}{c}{ Frequiência de citações } \\
e consumo & Número & Percentual \\
\cline { 2 - 3 } $\begin{array}{l}\text { Proteção à saúde, alimento mais } \\
\text { saudável }\end{array}$ & 21 & 58,3 \\
Alimento seguro por não conter & 8 & 22,3 \\
$\begin{array}{l}\text { agrotóxicos } \\
\text { Qualidade ou aparência superior }\end{array}$ & 4 & 11,2 \\
$\begin{array}{l}\text { Conveniência, ou seja, quando o } \\
\text { produto está disponível e o preço é } \\
\text { acessível }\end{array}$ & 2 & 5,5 \\
Preocupação com o meio ambiente & 1 & 2,7 \\
TOTAL & 36 & 100,0 \\
\hline
\end{tabular}

Com relação ao rol das motivações para a compra e consumo de produtos orgânicos, apresentadas na Tabela 26, é possível observar que a maioria das respostas dos consumidores, 58,3\% refere-se à proteção a saúde e/ou que são alimentos mais saudáveis. Essa motivação predominante foi também registrada por Cerveira \& Castro (1999) e Assis et al. (1995) tendo por base dados de pesquisas envolvendo consumidores de produtos orgânicos dos estados de São Paulo e Rio de Janeiro, respectivamente. Em pesquisa envolvendo consumidores de produtos orgânicos dos Estados Unidos, Govindasamy \& Itália (1999), registraram que a mais importante motivação revelada pelos consumidores americanos, no ato da compra de produtos orgânicos refere-se a maior sensibilidade para sua saúde e segurança. A referida motivação supera as demais, especialmente aquelas relativas aos outros benefícios e características da produção orgânica. 
$\mathrm{Na}$ presente pesquisa, tendo por base as respostas fornecidas pelos provadores, verificou-se $22,3 \%$ de referência ao alimento orgânico como "seguro por não conter agrotóxico". Em pesquisa realizada por Govindasamy \& Itália (1999), com base em uma amostra composta por 291 indivíduos foi possível observar que, 60\% responderam que os pesticidas causavam sérios riscos para a saúde humana, 37\% registraram que as referidas substâncias "eram um tanto quanto arriscadas", enquanto apenas 3\% responderam que não representavam riscos. Aproximadamente 55\% acreditavam que geralmente os produtos convencionais, eram seguros para o consumo, enquanto $44 \%$ não tinham certeza ou discordavam da afirmação. Foi observado também que, 58\% dos entrevistados acreditavam que existia uma diferença significativa relacionada a segurança, que favorecia o consumo de alimentos produzidos organicamente, em relação à produção convencional.

Misra et al. (1991) identificaram uma correlação negativa entre o nível educacional e a disposição a pagar por produtos livres de defensivos químicos sintéticos. Indivíduos com menor nível educacional revelaram maior propensão para considerar a superioridade dos produtos cultivados organicamente, quando comparados aos cultivados convencionalmente.

Farina \& Rezende (2001) realizaram um estudo (março de 2001), envolvendo 100 indivíduos, selecionados aleatoriamente entre os compradores da feira, onde se concentrava a maior parte da comercialização de produtos orgânicos, organizada pela Associação de Agricultura Orgânica (AAO) na cidade de São Paulo,. A maioria (78\%) dos entrevistados acreditava que o alimento orgânico era livre de qualquer tipo de contaminante prejudicial à saúde. Os entrevistados registraram que apenas compravam alimentos orgânicos porque acreditavam que os mesmos eram totalmente seguros. $\mathrm{O}$ resultado empírico sugere que consumidores brasileiros de produtos orgânicos pertencem a uma parcela da população com melhor nível educacional e com renda per capita acima da média nacional. Assim, este parece ser um consumidor diferenciado, ou seja, mais exigente e mais informado. No entanto, os consumidores não distinguiram contaminação por agroquímicos da contaminação microbiológica, classificando o 
alimento orgânico como um alimento seguro. Os autores ressaltam que a garantia da segurança dos alimentos depende de práticas adotadas, individualmente, pelos agentes que participam do sistema agroindustrial do alimento, o que faz da garantia de qualidade um problema que demanda coordenação sistemática.

Ainda de acordo com Farina \& Rezende (2001), o sistema brasileiro agroindustrial do tomate orgânico oferece um excelente exemplo da importância da coordenação do sistema para o êxito da adoção de um padrão de competição baseado em atributos de qualidade. Vale lembrar que o tomate, produzido convencionalmente, emprega elevadas quantidades de agroquímicos e é um alimento amplamente consumido in natura. O tomate é altamente susceptível à contaminação por agroquímicos e microrganismos. Por ser consumido cru, pode, se não reunir as características básicas de segurança e qualidade, provocar prejuízos para a saúde do consumidor.

Ainda de acordo com a Tabela 26, a qualidade ou aparência do produto sugerida como superior, recebeu em $11,2 \%$ das citações referentes às motivações para a compra de produtos orgânicos. A conveniência relacionada à disponibilidade do produto por um preço acessível recebeu 5,5\% das respostas. Ocupa a $5^{\circ}$ posição, com $2,7 \%$ das citações a preocupação com o meio ambiente. Cabe destacar que os resultados obtidos na presente pesquisa são concordantes com as análises elaborados por Cerveira \& Castro (1999). 
Tabela 27. Distribuição das citações dos entrevistados de acordo com as motivações para não comprar e não consumir alimentos orgânicos. Piracicaba, 2002.

Motivos registrados para não $\quad$ Freqüência de citações

comprar e consumir

Número

Percentual

Preço

21

52,5

Pouca oferta ou difícil acesso

9

22,5

Falta de hábito de consumir

4

10,0

produtos orgânicos

Falta de informação sobre o

4

10,0

produto

Qualidade ou aparência

2

inferior

TOTAL

40

100,0

Ao examinar os dados da Tabela 27, é possível verificar que o preço foi o motivo mais citado, pela maioria dos entrevistados (52,5\%), para não adquirir alimentos orgânicos. A reduzida oferta e o difícil acesso ao produto ocupa a segunda posição, recebendo 9 citações $(22,5 \%)$ dos entrevistados. Em pesquisa realizada por Govindasamy \& Itália (1999), 66\% dos participantes responderam que comprariam produtos orgânicos se esses estivessem prontamente disponíveis e 67\% revelaram uma disposição para comprar, desde que os referidos alimentos apresentassem um menor preço. Outras citações apresentadas como motivações para o não consumo os produtos orgânicos foram: a falta de hábito de consumir os produtos e falta de informações sobre os mesmos, ambas com o registro de $10 \%$ das citações. Esse resultado revela, mais uma vez, a importância do papel da mídia e dos especialistas para contribuir para os 
processos de esclarecimentos e conquistar potenciais consumidores desses produtos. A qualidade ou aparência inferior dos alimentos orgânicos, recebeu apenas $5 \%$ das respostas, resultado que sugere a ocorrência de uma expressiva mudança, por parte da parcela da população, no tocante ao conceito de qualidade desses produtos, quando comparada com posicionamentos pregressos.

A seguir serão apresentados os resultados obtidos, junto aos entrevistados, especificamente com referência ao tomate orgânico.

Tabela 28. Distribuição dos entrevistados, de acordo com o costume de comprar e consumir tomate orgânico. Piracicaba, 2002.

\begin{tabular}{rrcc}
\multicolumn{2}{l}{$\begin{array}{c}\text { Consumo de tomate } \\
\text { orgânico }\end{array}$} & & \multicolumn{2}{c}{ Freqüência } \\
\cline { 3 - 4 } & Sim & Número & Percentual \\
& Não & 15 & 27,8 \\
& TOTAL & 39 & 72,2 \\
& 54 & 100,0 \\
\hline
\end{tabular}

Nota: cálculos elaborados tendo por base o número $(n=54)$ de informações válidas.

Ao analisar os dados da Tabela 28 observa-se que apenas 15 indivíduos, ou seja, $27,8 \%$ do total de participantes da pesquisa afirmaram consumir tomate orgânico.

Tabela 29. Distribuição dos entrevistados, de acordo com a freqüência de consumo de tomate orgânico. Piracicaba, 2002.

\begin{tabular}{lcc}
\hline Freqüência de consumo & \multicolumn{3}{c}{ Freqüência } \\
\cline { 2 - 3 } & Número & Percentual \\
Diariamente & 6 & 40,0 \\
Semanalmente & 5 & 33,4 \\
Eventualmente & 4 & 26,6 \\
TOTAL & 15 & 100,0 \\
\hline
\end{tabular}

Nota: cálculos elaborados tendo por base o número $(n=15)$ referente ao total de entrevistados que informaram que consomem tomate orgânico. 
Conforme mostrado na Tabela 28, apenas 15 indivíduos afirmaram consumir tomate orgânico. Entre esses, $40 \%(n=6)$ informaram que o fazem diariamente, enquanto, 26,6\% alegaram que consomem eventualmente os alimentos produzidos organicamente (Tabela 29).

Tabela 30. Distribuição dos entrevistados de acordo com a disposição para pagar, com acréscimo, o preço do tomate orgânico (em relação ao valor pago pelo tomate convencional). Piracicaba, 2002.

\begin{tabular}{lcc}
\hline Acréscimo (percentual) no & \multicolumn{2}{c}{ Freqüência } \\
preço do tomate orgânico & Número & Percentual \\
\cline { 2 - 3 } Não pagaria qualquer & 8 & 13,6 \\
acréscimo & 25 & \\
25 & 11 & 42,4 \\
50 & 9 & 18,6 \\
87,5 & 4 & 15,3 \\
62,5 & 0 & 6,8 \\
150 & 2 & 0,0 \\
Não respondeu & 59 & 3,4 \\
TOTAL & & 100,0 \\
\hline
\end{tabular}

Quando questionados sobre o acréscimo (no preço) que estariam dispostos a pagar pelo tomate orgânico, em comparação ao que pagariam pelo alimento convencional, a maioria dos participantes $(42,4 \%)$ revelou disposição a pagar um valor adicional de $25 \%$ para adquirir o produto orgânico. No entanto, 18,6\% estariam dispostos a pagar $50 \%$ a mais pelo tomate orgânico. Cabe destacar que nenhum dos entrevistados revelou disposição para pagar $150 \%$ de acréscimo no preço, com vistas à 
aquisição do referido tipo de tomate. Entre os participantes, apenas 13,6\% não estariam dispostos a pagar qualquer valor adicional para adquirir o produto orgânico.

Govindasamy \& Italia (1999) sugerem em sua pesquisa que a maioria dos consumidores aceitaria pagar pelos produtos orgânicos um preço $10 \%$ superior aos tradicionalmente pagos pelos alimentos convencionais. Os autores identificaram certas características socio-demográficas capazes de afetar a tendência a pagar mais para consumir alimentos orgânicos. Entre os principais resultados, os autores destacaram: as mulheres são mais propensas a pagar valores adicionais, do que os homens; pessoas mais jovens têm maior disposição a pagar, com acréscimo, do que os mais idosos; consumidores com baixo nível de renda e com elevado nível de renda apresentam maior disposição a pagar mais pelo alimento orgânico, do que aqueles com nível de renda mediano; indivíduos com menor grau de escolaridade mostram maior propensão a pagar valores adicionais do que os indivíduos de maior nível de instrução; consumidores habituais de alimentos orgânicos têm maior disposição para pagar preços mais elevados do que os compradores eventuais; e membros de famílias menos numerosas são mais propensos a pagar mais caro pelo alimento do que aqueles, pertencentes a famílias mais numerosas.

Vale ainda apresentar algumas considerações tecidas Govindasamy \& Italia (1999), que identificaram algumas explicações para os hábitos de consumo. O fato de pessoas jovens aceitarem com maior facilidade o pagamento de um percentual adicional pelos orgânicos seria consequiência de sua maior propensão a mudanças de hábitos, menores restrições de dieta e maior nível de renda. No caso da escolaridade, consumidores com menor nível de escolaridade tenderiam a exagerar os efeitos de produtos químicos no organismo, enquanto aqueles com maior número de anos de estudos tenderiam a minimizar esses efeitos.

Pesquisa realizada por Weaver et al. (1992) indicou que 56\% dos consumidores teriam uma maior disposição a pagar, pelo menos, $10 \%$ a mais para obter tomates livres de agroquímicos e que apenas $19 \%$ não estavam dispostos a pagar mais pelo produto.

A disposição a pagar preços mais elevados por orgânicos foi constatada como decrescente de acordo com o aumento do tamanho da família. Essa disposição decresce 
8\% para cada pessoa adicional residindo junto com a família. Os resultados da pesquisa apresentada por Govindasamy \& Itália (1999) sugerem que a maior parte dos consumidores estaria disposta a pagar mais caro para obter produtos orgânicos e que certas características sócio-demograficas causam impacto na disposição a pagar por produtos orgânicos.

Tendo por base pesquisas implementadas em países desenvolvidos, descritas anteriormente, parece claro que em áreas, cuja economia local dispõe de famílias com rendimentos mais elevados e ainda, revelem tamanho mediano, podem ser o alvo preferencial para as estratégias do mercado de produtos orgânicos.

As referidas pesquisas também sugerem que os indivíduos que exibem maior disposição para comprar produtos orgânicos por um preço adicional exibem preocupações com segurança alimentar por se basearem em leituras sobre o assunto, atentarem para as notícias veiculadas, especialmente pela mídia, e exibem ainda maior disposição em experimentar o consumo de novos produtos. O nível educacional e a disposição a pagar por produtos isentos de pesticidas são características inversamente relatadas nas pesquisas.

Underhill \& Figueroa (1996) constataram que entre os participantes da pesquisa que conheciam os métodos de controle integrado de pragas, $20 \%$ revelaram disposição a pagar valor adicional de $10 \%$ por produtos orgânicos. Aqueles participantes que indicaram que estavam tentando introduzir recentemente esses alimentos na dieta revelaram disposição a pagar preço acrescido de 15\% pelo produto orgânico. Embora essas variáveis não sejam caracterizações tipicamente demográficas, elas ajudam a ilustrar possíveis caminhos para aproximar os potenciais consumidores de orgânicos. Aqueles que, freqüentemente, fizeram uso dos relatos da mídia, preocupando-se com segurança alimentar, estavam dispostos a pagar um preço adicional de $25 \%$ pelos produtos cultivados organicamente.

Nesta pesquisa, buscou-se conhecer a associação entre a disposição de pagar preços maiores para o tomate orgânico e o nível de renda familiar. Os resultados são apresentados a seguir, na Tabela 31. 
Tabela 31. Distribuição dos entrevistados, de acordo com os estratos de renda familiar (em salários mínimos) e os acréscimos (percentuais) no preço do tomate orgânico que os mesmos estão dispostos a pagar. Piracicaba, 2002.

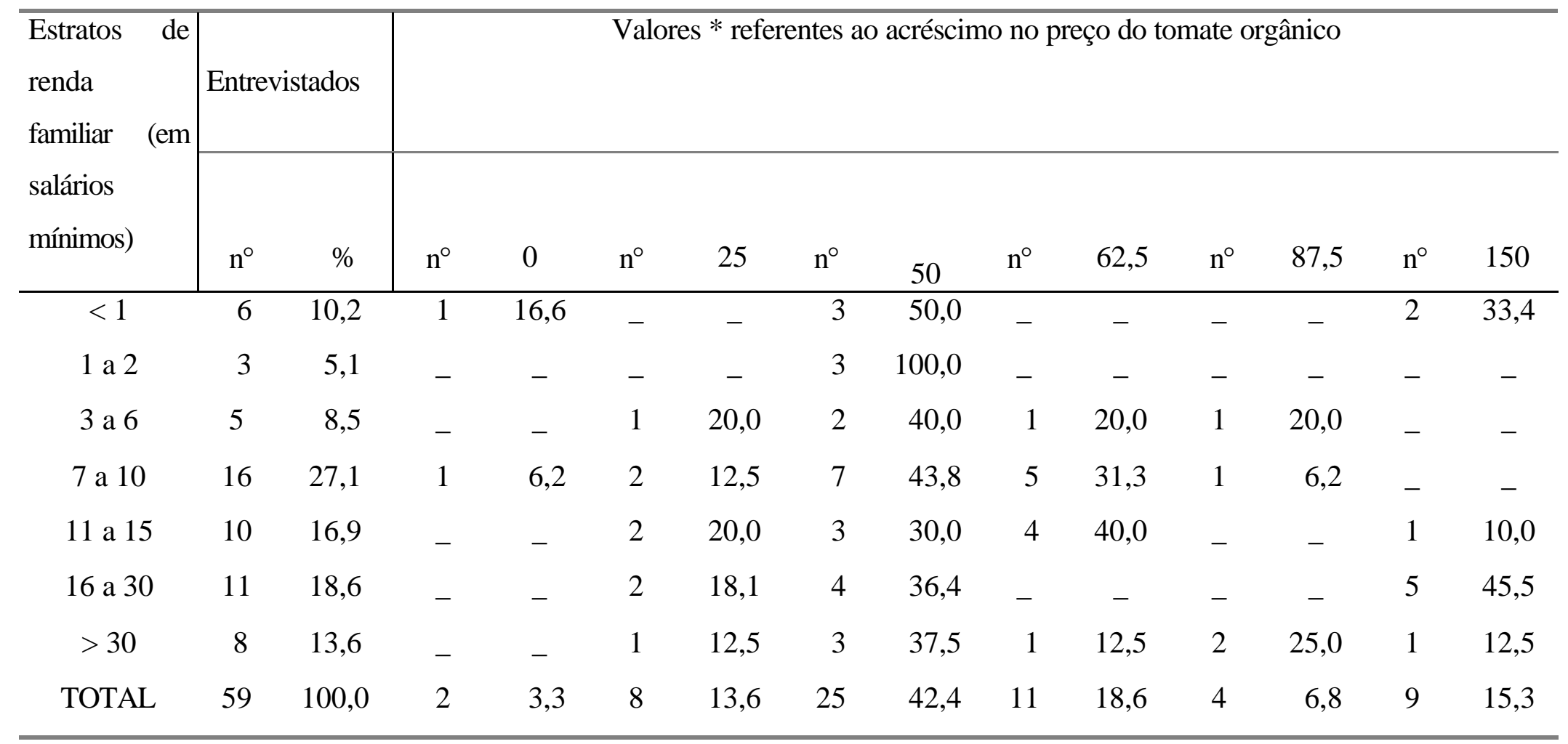

* Valores (em percentuais) adicionais citados pelos entrevistados para a aquisição de tomate orgânico. Nota: os traços significam que não foram obtidas respostas para a situação analisada.

$\chi^{2}=36,28$, com 30 graus de liberdade, não-significativo. 
Ao examinar os resultados é possível notar que há predomínio de proporção de entrevistados que alegaram disposição para o pagamento com acréscimo de $50 \%$ no preço, com vistas à aquisição do alimento orgânico. No entanto não foi possível, captar a associação estatisticamente significativa entre as variáveis renda familiar e o acréscimo no preço do tomate.

Wier \& Andersen (2001) analisaram diversas pesquisas sobre demanda por alimentos orgânicos, realizadas entre os anos de 1984 e 1999 na Dinamarca, França, Alemanha, Noruega, Suécia, Holanda e Estados Unidos. Em linhas gerais, os autores concluíram que as preocupações com a saúde são as principais motivações para a compra de alimentos orgânicos, sendo que o fato de serem considerados livres de pesticidas é reconhecido como uma característica importante desses produtos. Embora em menor escala, preocupações ambientais e com qualidade também são importantes na decisão dos consumidores para a compra de orgânicos.

Borguini \& Mattos (2002) analisaram algumas pesquisas, envolvendo consumidores brasileiros - nos anos de 1992, 1996, 1998 e 1999 - e constataram que os resultados foram bastante semelhantes, para os diferentes anos. De forma geral, pode-se dizer que: o consumidor brasileiro de produtos orgânicos tem como principal motivação a preocupação com sua saúde e de sua família; a maioria dos consumidores está disposta a pagar um preço mais elevado pelos alimentos orgânicos; parcela expressiva dos consumidores não tem consciência clara do significado da agricultura orgânica; e que muitos consumidores gostariam de contar com uma oferta mais diversificada de alimentos orgânicos, tanto em relação à quantidade de produtos como no que tange os pontos de venda.

Segundo Assis (2002), o atrativo deste mercado se deve ao sobre-preço dos produtos orgânicos, o qual decorre da função da demanda de um público disposto a pagar mais por um alimento com atributos nem sempre facilmente tangíveis, mas que envolvem relação de confiança entre produtor/certificador/consumidor. Porém, se por um lado a oferta é, ainda hoje, insuficiente para atender a demanda de um público consumidor ávido por alimentos orgânicos em diversidade e quantidade, este mesmo público apresenta limites em sua disposição para o pagamento. 


\section{CONCLUSÕES}

As informações obtidas indicam que existem diferenças relativas à qualidade, quando são considerados atributos como o sabor, o valor nutricional entre outros critérios, mediante comparação entre os alimentos produzidos pelos métodos orgânico e convencional. As evidências, no entanto, não são suficientes para tomada de posições definitivas em relação ao alimento produzido organicamente, ou seja, assumir a sua possível superioridade no tocante à qualidade (nutricional e organoléptica) e os benefícios do seu consumo, para a saúde do consumidor. Desse modo, recomenda-se que maior número de pesquisas sejam desenvolvidas, analisando, pormenorizadamente, os aspectos qualitativos e ainda, examinando uma ampla gama de produtos.

* Considerando a opinião do consumidor, preocupações com a saúde foram as principais motivações para a compra de alimentos orgânicos, sendo o fato de serem considerados livres de pesticidas uma característica importante, citada pelos entrevistados. Embora em menor escala, preocupações ambientais e com a qualidade dos produtos também foram citadas como decisivas para a compra de orgânicos. Com relação às restrições ao consumo de alimentos orgânicos, destacam-se os preços elevados e a disponibilidade limitada.

* Pode-se dizer que a redução do diferencial de preço seria um importante instrumento para ampliar o acesso de maior parcela da população, aos produtos 
orgânicos. Na presente pesquisa, a maior parte dos consumidores declarou disposição para pagar um maior preço pelos produtos orgânicos.

* Por meio das análises elaboradas, é possível reconhecer o importante papel que especialistas podem assumir, especialmente com vistas à melhor informar $\mathrm{o}$ consumidor sobre as características dos produtos orgânicos.

* Para o atendimento das recomendações nutricionais estabelecidas mais recentemente, se torna essencial aumentar a participação de alimentos de origem vegetal na dieta, de indivíduos de todas as faixas de idade. Face ao exposto, parece indispensável colocar em prática os métodos de produção que permitam a diminuição dos teores de nitrato e dos resíduos de agroquímicos nos alimentos. Para tanto, os métodos da agricultura orgânica parecem ampliar o rol de perspectivas benéficas para a saúde pública. 
ANEXOS 
ANEXO A - Ficha adotada para os registros dos provadores, relativos à avaliação dos frutos, durante a análise sensorial.

\section{UNIVERSIDADE DE SÃO PAULO}

Escola Superior de Agricultura "Luiz de Queiroz"

Departamento de Agroindústria, Alimentos e Nutrição

Curso de Pós-graduação em Ciência e Tecnologia de Alimentos

Nome: Telefone:

Muito obrigado por participar de nossa pesquisa com tomate. Você receberá DUAS amostras de tomate para avaliar. Por favor, leia este questionário antes de iniciar o teste, depois prove o produto e responda as questões que se seguem:

1. Indique o quanto você gostou do aroma do produto:

( ) gostei extremamente

( ) gostei moderadamente

( ) gostei regularmente

( ) gostei ligeiramente

( ) não gostei nem desgostei

( ) desgostei ligeiramente

( ) desgostei regularmente

( ) desgostei moderadamente

( ) desgostei extremamente

2. Indique o quanto você gostou do sabor do produto:

( ) gostei extremamente

( ) gostei moderadamente

( ) gostei regularmente

( ) gostei ligeiramente

( ) não gostei nem desgostei

( ) desgostei ligeiramente

( ) desgostei regularmente

( ) desgostei moderadamente

( ) desgostei extremamente 
3. Indique o quanto você gostou da cor do produto:

( ) gostei extremamente

( ) gostei moderadamente

( ) gostei regularmente

( ) gostei ligeiramente

( ) não gostei nem desgostei

( ) desgostei ligeiramente

( ) desgostei regularmente

( ) desgostei moderadamente

( ) desgostei extremamente

4. Indique o quanto você gostou de maneira geral do produto:

( ) gostei extremamente

( ) gostei moderadamente

( ) gostei regularmente

( ) gostei ligeiramente

( ) não gostei nem desgostei

( ) desgostei ligeiramente

( ) desgostei regularmente

( ) desgostei moderadamente

( ) desgostei extremamente

5. Comentários: por favor, indique o que em particular você mais gostou ou menos gostou neste produto (use palavras ou frases):

Mais gostei:

Menos gostei:

6. Qual a sua faixa de idade?

( ) 18 a 25 anos

( ) acima de 25 a 35 anos

( ) acima de 35 anos 
7. Você costuma consumir esse tipo de produto?

( ) Sim, diariamente

( ) Sim, de vez em quando (com que freqüência?

( ) Sim, raramente

( ) Nunca

8. Como você escolhe o tomate na hora da compra?

( ) Pelo preço (o que estiver mais barato)

( ) Pela qualidade, considerando experiência de uso anterior

( ) Pela combinação preço e qualidade, considerando experiência anterior. 
ANEXO B - Formulário adotado para caracterização socioeconômica, estilo de vida e consumo de alimentos orgânicos.

\author{
UNIVERSIDADE DE SÃO PAULO \\ Escola Superior de Agricultura "Luiz de Queiroz" \\ Departamento de Agroindústria, Alimentos e Nutrição \\ Curso de Pós-graduação em Ciência e Tecnologia de Alimentos
}

1. Nome:

2. Sexo: ( ) Feminino ( ) Masculino

3. Informe (marcando somente uma alternativa), a seguir, a sua escolaridade:

( ) não freqüentou escola

( ) $1^{\circ}$ grau incompleto

( ) $1^{\circ}$ grau completo (ou equivalente)

( ) $2^{\circ}$ grau incompleto

( ) $2^{\circ}$ grau completo (ou equivalente)

( ) faculdade

( ) pós-graduação 
4. O (a) senhor(a) ao escolher o tomate durante a compra, considera:

( ) o preço (adquire o que estiver mais barato)

( ) a aparência

( ) características que revelem que terá maior durabilidade

( ) garantia (existência) de informação que não tem resíduos

( ) sabor / aroma

( ) informações que garantam que tem maior quantidade de nutriente

( ) outra: Qual?

5. Com que frequiência você costuma consumir tomate? (assinale somente uma alternativa)

( ) Diariamente

( ) Semanalmente

( ) De vez em quando

( ) Raramente

( ) Nunca

6. O(a) senhor(a) alterou a quantidade de tomate consumida (nos últimos meses) após receber orientação?

( ) $\operatorname{Sim}$

( ) Não

No caso de ter recebido orientação, marque a origem da informação:

( ) Médico

( ) Informação de revista

( ) Nutricionista

( ) Informação de jornal

( ) Farmacêutico

( ) Informação de programa de televisão

( ) Amigos/parentes

( ) outros. Qual(is): 
7. O que o(a) senhor(a) entende por produtos ou alimentos orgânicos? (utilize palavras ou frases)

8. Onde obteve essas informações?
( ) livros
( ) Internet
( ) revistas
( ) Sala de aula
( ) jornal
( ) Amigo/parente
( ) televisão
( ) Outros (.....
( ) médico

9. O(a) senhor(a) costuma comprar e consumir alimentos orgânicos?
( ) $\mathrm{Sim}$
( ) Não

Se respondeu NÃO, por favor escreva o(s)

motivo(s):

Se respondeu SIM, por favor escreva o(s)

motivo(s):

10. No caso do(a) senhor(a) ter respondido que consome alimentos orgânicos, marque a freqüência.
( ) Diariamente
( ) Semanalmente
( ) De vez em quando
( ) Raramente
( ) Nunca 
11. Que tipo de produtos orgânicos você costuma comprar ou consumir?

( ) Hortaliças (quais:

( ) Frutas

( ) Laticínios

( ) Cereais

( ) Carnes

( ) Ovos

( ) Alimentos prontos para o consumo

(quais:

12. No caso do(a) senhor(a) consumir produtos orgânicos, marque o local onde costuma adquirir os produtos.

( ) Feira de produtos orgânicos

( ) Feira comum

( ) Supermercado

( ) Quitanda ou varejão

( ) Entrega domiciliar

( ) Loja de produtos naturais

( ) Outros

Qual(is):

13. O(a) senhor(a) costuma consumir tomate orgânico?

( ) $\mathrm{Sim}$

( ) Não 
14. Com que frequiência você costuma consumir tomate orgânico?

( ) Diariamente

( ) Semanalmente

( ) De vez em quando

( ) Raramente

( ) Nunca

15. Vamos supor que o tomate comum seja vendido a um preço de $\mathrm{R} \$ 0,80$ o quilo. Marque o valor que o(a) senhor(a) estaria disposto(a) a pagar pelo tomate orgânico (marque somente uma resposta). Marque:

( ) não pagaria mais pelo tomate

( ) pagaria $\mathrm{R} \$ 1,00$ (um real)

( ) pagaria $\mathrm{R} \$ 1,20$ (um real e vinte centavos)

( ) pagaria $\mathrm{R} \$ 1,30$ (um real e trinta centavos)

( ) pagaria $\mathrm{R} \$ 1,50$ (um real e cinqüenta centavos)

( ) pagaria $\mathrm{R} \$ 3,00$ (três reais)

16. Em qual faixa de renda, aproximadamente, você coloca o seu ganho mensal (ex.: pensão, salário, aluguel, etc)? (S.M. significa Salário Mínimo por mês)

( ) não tem ( ) até 1 S.M. ( ) 1-2 S.M. ( ) 3-6 S.M. ( ) 7-10 S.M. ( ) 11-15 S.M. ( ) 16-30 S.M. ( ) maior que 30 S.M.

17. Em qual faixa de renda, aproximadamente, você coloca o ganho mensal de sua família (soma de todos os ganhos das pessoas que dividem as despesas. Ex.: pensão, salário, aluguel, etc)? (S.M. significa Salário Mínimo por mês)

( ) até 1 SM ( ) 1-2 S.M. ( ) 3-6 S.M. ( ) 7-10 S.M. ( ) 11-15 S.M. ( ) 16-30 S.M. ( ) maior que 30 S.M. 
18. Informe o número de pessoas que integram a sua família?

19. Você tem algum hábito alimentar diferenciado?
( ) Vegetariano
( ) Naturalista
( ) Macrobiótico

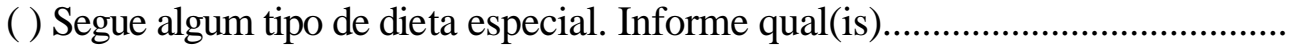

( ) Motivo religioso. Informe qual(is).

( ) Outros, por favor escreva........

Muito obrigada pela sua colaboração! 
ANEXO C - Distribuição da opinião dos provadores, com relação ao aroma dos frutos de tomate in natura dos cultivares Carmem e Débora, produzidos pelos métodos de cultivo convencional e orgânico.

\begin{tabular}{|c|c|c|c|c|c|c|c|c|}
\hline \multirow{4}{*}{$\begin{array}{l}\text { Descrição da } \\
\text { Escala Hedônica }\end{array}$} & \multicolumn{8}{|c|}{ AROMA } \\
\hline & \multicolumn{4}{|c|}{ CARMEM } & \multicolumn{4}{|c|}{ DÉBORA } \\
\hline & \multicolumn{2}{|c|}{ Convencional } & \multicolumn{2}{|c|}{ Orgânico } & \multicolumn{2}{|c|}{ Convencional } & \multicolumn{2}{|c|}{ Orgânico } \\
\hline & $\mathrm{n}^{\circ}$ & $\%$ & $\mathrm{n}^{\circ}$ & $\%$ & $\mathrm{n}^{\circ}$ & $\%$ & $\mathrm{n}^{\circ}$ & $\%$ \\
\hline \multicolumn{9}{|l|}{ Gostei } \\
\hline extremamente & 15 & 35,7 & 10 & 23,3 & 13 & 39,4 & 11 & 32,4 \\
\hline \multicolumn{9}{|l|}{ Gostei } \\
\hline moderadamente & 15 & 35,7 & 16 & 37,2 & 12 & 36,4 & 14 & 41,2 \\
\hline \multicolumn{9}{|l|}{ Gostei } \\
\hline regularmente & 5 & 11,9 & 7 & 16,3 & 4 & 12,1 & 1 & 2,9 \\
\hline \multicolumn{9}{|l|}{ Gostei } \\
\hline ligeiramente & 4 & 9,5 & 3 & 7,0 & 2 & 6,1 & 5 & 14,7 \\
\hline \multicolumn{9}{|l|}{ Não gostei nem } \\
\hline desgostei & 1 & 2,4 & 3 & 7,0 & 1 & 3,0 & 1 & 2,9 \\
\hline \multicolumn{9}{|l|}{ Desgostei } \\
\hline ligeiramente & 1 & 2,4 & 2 & 4,7 & 1 & 3,0 & 2 & 5,9 \\
\hline \multicolumn{9}{|l|}{ Desgostei } \\
\hline regularmente & 1 & 2,4 & 2 & 4,7 & - & - & - & _ \\
\hline \multicolumn{9}{|l|}{ Desgostei } \\
\hline moderadamente & - & - & - & - & - & - & - & - \\
\hline \multicolumn{9}{|l|}{ Desgostei } \\
\hline extremamente & - & - & - & - & - & - & - & - \\
\hline TOTAL & 42 & 100,0 & 43 & 100,0 & 33 & 100,0 & 34 & 100,0 \\
\hline
\end{tabular}

Nota: os traços significam que não foram registradas informações pelos provadores. 
ANEXO D - Distribuição da opinião dos provadores, com relação ao sabor dos frutos de tomate in natura dos cultivares Carmem e Débora, produzidos pelos métodos de cultivo convencional e orgânico.

\begin{tabular}{|c|c|c|c|c|c|c|c|c|}
\hline \multirow{4}{*}{$\begin{array}{l}\text { Descrição da } \\
\text { Escala Hedônica }\end{array}$} & \multicolumn{8}{|c|}{ SABOR } \\
\hline & \multicolumn{4}{|c|}{ CARMEM } & \multicolumn{4}{|c|}{ DÉBORA } \\
\hline & \multicolumn{2}{|c|}{ Convencional } & \multicolumn{2}{|c|}{ Orgânico } & \multicolumn{2}{|c|}{ Convencional } & \multicolumn{2}{|c|}{ Orgânico } \\
\hline & $\mathrm{n}^{\circ}$ & $\%$ & $\mathrm{n}^{\circ}$ & $\%$ & $\mathrm{n}^{\circ}$ & $\%$ & $\mathrm{n}^{\circ}$ & $\%$ \\
\hline \multicolumn{9}{|l|}{ Gostei } \\
\hline extremamente & 12 & 27,9 & 7 & 16,3 & 16 & 47,1 & 7 & 21,2 \\
\hline \multicolumn{9}{|l|}{ Gostei } \\
\hline moderadamente & 18 & 41,9 & 12 & 27,9 & 11 & 32,4 & 9 & 27,3 \\
\hline \multicolumn{9}{|l|}{ Gostei } \\
\hline regularmente & 7 & 16,3 & 6 & 14,0 & 4 & 11,8 & 6 & 18,2 \\
\hline \multicolumn{9}{|l|}{ Gostei } \\
\hline ligeiramente & 3 & 7,0 & 8 & 18,6 & 2 & 5,9 & 4 & 12,1 \\
\hline Não gostei nem & & & & & & & 1 & \\
\hline desgostei & 1 & 2,4 & 3 & 7,0 & 1 & 3,0 & & 2,9 \\
\hline Desgostei & & & & & & & 3 & \\
\hline ligeiramente & 2 & 4,7 & 3 & 7,0 & - & - & & 9,1 \\
\hline \multicolumn{9}{|l|}{ Desgostei } \\
\hline regularmente & - & - & 1 & 2,3 & - & - & 1 & 3,0 \\
\hline \multicolumn{9}{|l|}{ Desgostei } \\
\hline moderadamente & - & - & 1 & 2,3 & 1 & 2,9 & 1 & 3,0 \\
\hline \multicolumn{9}{|l|}{ Desgostei } \\
\hline extremamente & - & - & 1 & 2,3 & - & - & - & - \\
\hline TOTAL & 43 & 100,0 & 43 & 100,0 & 34 & 100,0 & 33 & 100,0 \\
\hline
\end{tabular}

Nota: os traços significam que não foram registradas informações pelos provadores. 
ANEXO E - Distribuição da opinião dos provadores, com relação à cor dos frutos de tomate in natura dos cultivares Carmem e Débora, produzidos pelos métodos de cultivo convencional e orgânico.

\begin{tabular}{|c|c|c|c|c|c|c|c|c|}
\hline \multirow{4}{*}{$\begin{array}{l}\text { Descrição da } \\
\text { Escala Hedônica }\end{array}$} & \multicolumn{8}{|c|}{ COR } \\
\hline & \multicolumn{4}{|c|}{ CARMEM } & \multicolumn{4}{|c|}{ DÉBORA } \\
\hline & \multicolumn{2}{|c|}{ Convencional } & \multicolumn{2}{|c|}{ Orgânico } & \multicolumn{2}{|c|}{ Convencional } & \multicolumn{2}{|c|}{ Orgânico } \\
\hline & $n^{\circ}$ & $\%$ & $\mathrm{n}^{\circ}$ & $\%$ & $\mathrm{n}^{\circ}$ & $\%$ & $\mathrm{n}^{\circ}$ & $\%$ \\
\hline \multicolumn{9}{|l|}{ Gostei } \\
\hline extremamente & 17 & 35,4 & 15 & 31,9 & 15 & 44,1 & 12 & 36,4 \\
\hline \multicolumn{9}{|l|}{ Gostei } \\
\hline moderadamente & 11 & 22,9 & 20 & 42,6 & 10 & 29,4 & 10 & 30,3 \\
\hline \multicolumn{9}{|l|}{ Gostei } \\
\hline regularmente & 8 & 16,7 & 4 & 8,5 & 6 & 17,6 & 4 & 12,1 \\
\hline \multicolumn{9}{|l|}{ Gostei } \\
\hline ligeiramente & 8 & 16,7 & 3 & 6,4 & - & _- & 3 & 9,1 \\
\hline \multicolumn{9}{|l|}{ Não gostei nem } \\
\hline desgostei & 2 & 4,2 & 3 & 6,4 & 1 & 2,9 & 1 & 3,0 \\
\hline \multicolumn{9}{|l|}{ Desgostei } \\
\hline ligeiramente & 1 & 2,1 & - & - & 1 & 2,9 & 1 & 3,0 \\
\hline \multicolumn{9}{|l|}{ Desgostei } \\
\hline regularmente & - & - & 2 & 4,3 & 1 & 2,9 & 2 & 6,1 \\
\hline \multicolumn{9}{|l|}{ Desgostei } \\
\hline moderadamente & 1 & 2,1 & - & - & - & - & - & - \\
\hline \multicolumn{9}{|l|}{ Desgostei } \\
\hline extremamente & - & - & - & - & - & - & - & - \\
\hline TOTAL & 48 & 100,0 & 47 & 100,0 & 34 & 100,0 & 33 & 100,0 \\
\hline
\end{tabular}

Nota: os traços significam que não foram registradas informações pelos provadores. 
ANEXO F - Distribuição da opinião dos provadores, com relação ao aspecto geral dos frutos de tomate in natura dos cultivares Carmem e Débora, produzidos pelos métodos de cultivo convencional e orgânico.

\begin{tabular}{|c|c|c|c|c|c|c|c|c|}
\hline \multirow{4}{*}{$\begin{array}{l}\text { Descrição da } \\
\text { Escala Hedônica }\end{array}$} & \multicolumn{8}{|c|}{ ASPECTO GERAL } \\
\hline & \multicolumn{4}{|c|}{ CARMEM } & \multicolumn{4}{|c|}{ DÉBORA } \\
\hline & \multicolumn{2}{|c|}{ Convencional } & \multicolumn{2}{|c|}{ Orgânico } & \multicolumn{2}{|c|}{ Convencional } & \multicolumn{2}{|c|}{ Orgânico } \\
\hline & $\mathrm{n}^{\circ}$ & $\%$ & $\mathrm{n}^{\circ}$ & $\%$ & $n^{\circ}$ & $\%$ & $\mathrm{n}^{\circ}$ & $\%$ \\
\hline \multicolumn{9}{|l|}{ Gostei } \\
\hline extremamente & 7 & 14,9 & 20 & 41,7 & 11 & 33,3 & 11 & 32,4 \\
\hline \multicolumn{9}{|l|}{ Gostei } \\
\hline moderadamente & 18 & 38,3 & 18 & 37,5 & 11 & 33,3 & 12 & 35,3 \\
\hline \multicolumn{9}{|l|}{ Gostei } \\
\hline regularmente & 10 & 21,3 & 5 & 10,4 & 8 & 24,2 & 6 & 17,6 \\
\hline \multicolumn{9}{|l|}{ Gostei } \\
\hline ligeiramente & 7 & 14,9 & 3 & 6,3 & 1 & 3,0 & 2 & 5,9 \\
\hline \multicolumn{9}{|l|}{ Não gostei nem } \\
\hline desgostei & 2 & 4,3 & 2 & 4,2 & - & - & - & - \\
\hline \multicolumn{9}{|l|}{ Desgostei } \\
\hline ligeiramente & 2 & 4,3 & - & - & 2 & 6,1 & 1 & 2,9 \\
\hline \multicolumn{9}{|l|}{ Desgostei } \\
\hline regularmente & 1 & 2,1 & - & - & - & - & 2 & 5,9 \\
\hline \multicolumn{9}{|l|}{ Desgostei } \\
\hline moderadamente & - & - & - & - & - & - & - & - \\
\hline \multicolumn{9}{|l|}{ Desgostei } \\
\hline extremamente & - & - & - & - & - & - & - & - \\
\hline TOTAL & 47 & 100,0 & 48 & 100,0 & 33 & 100,0 & 34 & 100,0 \\
\hline
\end{tabular}

Nota: os traços significam que não foram registradas informações pelos provadores. 


\section{REFERÊNCIAS BIBLIOGRÁFICAS}

ALMEIDA, C. Determinação da firmeza e cor do tomate (Lycopersicum esculentum Mill), visando o estabelecimento de correlações entre medidas sensoriais e físicas ao longo do tempo de maturação. Campinas, 1995. 102p. Dissertação (Mestrado) Faculdade de Engenharia Agrícola, Universidade de Campinas.

ARAÚJO, A.C.P.; NOGUEIRA, D.P.; AUGUSTO, L.G.S. Impacto dos praguicidas na saúde: estudo da cultura de tomate. Revista de Saúde Pública, v.34, n.3, p.309-13, 2000.

ASSIS, R.L. Agroecologia no Brasil: análise do processo de difusão e perspectivas. Campinas, 2002. 150p. Tese (Doutorado) - Instituto de Economia, Universidade de Campinas.

ASSIS, R.L.; AREZZO, D.C. de; DE-POLLI, H. Consumo de produtos da agricultura orgânica no estado do Rio de Janeiro. Revista de Administração, v.30, n.1, p.84-89, 1995.

ASSOCIATION OF OFFICIAL ANALYTICAL CHEMISTS. Official methods of analysis. 16.ed. Arlington: AOAC, 1995. cap.45, p.18-19. 
AUBERT, C. Palestra: Engenheiro Agrônomo Claude Aubert. In: ENCONTRO BRASILEIRO DE AGRICUlTURA ALTERNATIVA, 1., Curitiba, 1981. Anais. Curitiba: Federação dos Engenheiros Agrônomos do Brasil/Associação dos Engenheiros Agrônomos do Paraná, 1981. p.161-190.

BORGUINI, R.G.; MATTOS, F.L. Análise do consumo de alimentos orgânicos no Brasil. In: CONGRESSO BRASILEIRO DE ECONOMIA E SOCIOLOGIA RURAL, 40., Passo Fundo, 2002. Anais. Brasília: SOBER, 2002. p.38.

BOURNE, M.C. Effect of temperature on firmness of raw fruits and vegetables. Journal of Food Science, v.47, n.2, p.440-444, 1982.

CALDAS, E.D.; SOUZA, L.C.K. Avaliação de risco crônico da ingestão de resíduos de pesticidas na dieta brasileira. Revista de Saúde Pública, v.34, n.5, p.529-37, 2000.

CALVERT, J. Organic horticulture and nutrition. The best of permaculure. Nambour: Nascimanere, 1986. p.8-9.

CARVALHO, P.R.N.; COLLINS, C.A.; RODRIGUEZ-AMAYA, D.B. Comparison of provitamin A determination by normal-phase gravity-fow column chromatography and reversed phase high peformance liquid chromatography. Chromatographia, v.33, n.3/4, p.133-37, 1992.

CERVEIRA, R.; CASTRO.M.C.de. Consumidores de produtos orgânicos da cidade de São Paulo: características de um padrão de consumo. Informações Econômicas, v.29, n.12, p.7-19, 1999.

CHITARRA, M.I.F. Colheita e qualidade pós-colheita de frutos. Informe Agropecuário, v.17, n.179, p.8-18, 1994. 
CHITARRA, M.I.F.; CHITARRA, A.B. Pós-colheita de frutos e hortaliças: fisiologia e manuseio. Lavras: Fundação de Apoio ao Ensino, Pesquisa e Extensão, 1990. 293p.

COMPANHIA DE ENTREPOSTOS E ARMAZÉNS GERAIS DO ESTADO DE SÃO PAULO. Classificação de tomate. São Paulo: CEAGESP, s.d. 3p.

COSTA, I.T.L.B. Tomate industrial: perspectivas de mercado. Bahia Agrícola, v.2, n.2, p.30-38, 1998.

EHLERS, E. Agricultura sustentável: origens e perspectivas de um novo paradigma. São Paulo: Livro da Terra, 1996. 178p.

ESPINOZA, W. Manual de produção de tomate industrial no Vale do São Francisco. Brasília: IICA, Escritório no Brasil, 1991. 301p.

FAO/ORGANIZAÇÃO MUNDIAL DA SAÚDE. El codex alimentarius: directrices para la producción, elaboración, etiquetado y comercialización de alimentos producidos orgánicamente. Roma, 1999. http://www.fao.org (05 Sept. 2001)

FARINA, E.M.M.Q.; REZENDE, C.L. Changing competition patterns in a weak regulatory environment: the case of organic products in Brazil. In: SYMPOSIUM INTERNATIONAL FOOD AND AGRIBUSINESS MANAGEMENT ASSOCIATION. Sidney, $2001 . \quad$ Anais. http://www.informa.org/conferences/2001conference/Papers/ (15 May 2002)

FNP CONSULTORIA \& COMÉRCIO. Tomate para mesa, a prioritária exigência de qualidade. Agrianual 2001. São Paulo, 2001. p.65-67. 
GLASER, L.K.; THOMPSON, G.D. Demand for organic and conventional frozen vegetables. In: AMERICAN AGRICULTURAL ECONOMICS ASSOCIATION ANNUAL MEETING, Nashiville, 1998. Selected Paper. Ames: AMERICAN AGRICULTURAL ECONOMICS ASSOCIATION, $1998 . \quad$ p.1-14. http://www.ers.usda.gov/publications/aib777/aib777rf.pdf(15 May 2002)

GOVINDASAMY, R.; ITALIA, J. Predicting willingness-to-pay a premium for organically grown fresh produce. Journal of Food Distribution Research, v.30, n.2, p.44-53, July 1999.

HAVARD, K.A.; WARMAN, P.R. Yield, vitamin and mineral contents of organically and conventionally grown carrots and cabbage. Agriculture, Ecosystems \& Environment, v.61, p.155-62, 1997.

INOCUIDAD y calidad de los alimentos en relación con la agricultura orgánica. In: CONFERÊNCIA REGIONAL DE LA FAO PARA EUROPA, 22., Oporto, 2000. Rome: FAO, 2000. p.1-69.

INSTITUTO BRASILEIRO DE GEOGRAFIA E ESTATÍSTICA. Pesquisa de Orçamentos Familiares 1995-1996: consumo alimentar domiciliar per capita. Rio de Janeiro, 1998. v.2, p.27.

KHATOUNIAN, C.A. Algumas considerações sobre olericultura orgânica. Horticultura Brasileira, v.12, n.2, p.256-58, 1994.

LAIRON, D. Efecto de las fertilizaciones orgánicas y minerales sobre el valor nutritivo de las producciones agrícolas. In: CONGRESSO CIENTÍFICO EUROPEU DE AGRICUlturA BIOLÓGICA, Madrid, 1985. Ponencias y Comunicaciones. Madrid: IFOAM/Asociacion Vida Sana, 1985. p.254-271. 
LAMPKIN, N. The wider issues. In: Organic farming. Ipswich: Press Books, 1990. cap.15, p.557-616.

LITTLE, A.C. Physical measurements as predictors of visual appearance. Food Tecnology, v.10, n.30, p.74-82, 1976.

LOHR, L. Factors affecting international demand and trade in organic food products. Athens: University of Georgia, Department of Agricultural and Applied Economics, Nov. 2000. p.1-35. (Faculty Series 00-20) http://www.agecon.ug.edu/publications/00pubs.html (15 May 2002)

LUENGO, R.F.A.; PARMAGNANI, R.M.; PARENTE, M.R.; LIMA, M.R.B.F. Tabela de composição nutricional das hortaliças. Brasília: EMBRAPA Hortaliças, 2000. 4p. (Documentos, 26)

MAEDER, P.; FLIESSBACH, A.; DUBOIS, D.; GUNST, L.; FRIED, P.; NIGGLI, U. Soil fertility and biodiversity in organic farming. Science Magazine, v.296, n.5573, p.1694, 2002.

McGUIRRE, R.G. Reporting of objective color measurements. Hort Science, v.17, n.12, p.1254-1255, 1992.

MINAMI, K.; HAAG, P.H. O tomateiro. 2.ed. Campinas: Fundação Cargill, 1989. $397 \mathrm{p}$.

MISRA, S.; HUANG, C.; OTT, S. Consumer willingness to pay for pesticide-free fresh produce. Western Journal of Agricultural Economics, v.16, n.2, p.218-227, 1991.

NGUEM, M.L.; SHWARZ, S.J. Lycopene: chemical and biological properties. Food Technology, v.53, n.2, p.38-45, 1999. 
ORMOND, J.G.P.; PAULA, S.R.L.; FAVERET FILHO, P.; ROCHA, L.T.M. Agricultura orgânica: quando o passado é futuro. BNDES Setorial, n.15, p.3-34, 2002.

PADOVANI, M.I. Tomate: o "fruto do amor" que conquistou o mundo. São Paulo: Ícone, 1986. 152p.

PASCHOAL, A.D. Produção orgânica de alimentos: agricultura sustentável para os séculos XX e XXI. Piracicaba: EDUSP, 1994. 323p.

PEÑA, R.P. Rendimento, qualidade e conservação pós-colheita de cenoura (Daucus Carola L.) sob adubações mineral, orgânica e biodinâmica. Botucatu, 1996. 93p. Dissertação (Mestrado) - Faculdade de Ciências Agronômicas, Universidade Estadual Paulista.

PENTEADO, S.R. Introdução à agricultura orgânica. Campinas: Grafimagem, 2000. $110 \mathrm{p}$.

PENTEADO, S.R. Defensivos alternativos e naturais: para uma agricultura saudável. 3.ed. Campinas, 2001. 96p.

PREGNOLATTO, W.; PREGNOLATTO, N.P. Normas analíticas do Instituto Adolfo Lutz, São Paulo: Instituto Adolfo Lutz, 1985. 578p.

RODET, J.C. Por que agricultura orgânica ? São Paulo: TAPS, s.d. 4p.

RODRIGUEZ-AMAYA, D.B. Os carotenóides como precursores de vitamina A. Boletim da Sociedade Brasileira de Ciência e Tecnologia de Alimentos, v.19, n.4, p.227-332, 1985. 
SARRUGE, J.R.; HAAG, H.P. Análises químicas em plantas. Piracicaba: ESALQ, Depto. de Química, 1974. 56p.

SAS INSTITUTE. The SAS System (software). Versão 8. Cary, 1998.

SETSER, C.S. Color: reflections and transmissions. Journal of Food Quality, n.6, p.183-197, 1984.

SCHAUMANN, W. Alimentação e agricultura. São Paulo: Associação Beneficente Tobias, s.d. 16p. (Higiene social. Folheto de medicina preventiva para a saúde individual e coletiva. Alimentação e Agricultura, 18)

SCHUPHAN, W. Nutritive value of crops as influenced by organic and inorganic fertilizer treatment. Qualitas Plantarum: plant foods for human nutrition, v.23, n.4, p.333-58, 1974.

SILVA, M.M. Avaliação dos teores foliares de micronutrientes em citros em função da aplicação de fungicidas, sais e quelatizados. Piracicaba, 1996. 58p. Dissertação (Mestrado) - Escola Superior de Agricultura "Luiz de Queiroz", Universidade de São Paulo.

SMITH, B.L. Organic foods vs. supermarket foods: element levels. Journal of Applied Nutrition, v.45, n.1, p.35-39, 1993.

SOUZA, M.C.M. Produtos orgânicos. In: ZYLBERSZTAJN, D.; NEVES, M.F. (Org.). Economia e gestão dos negócios agro-alimentares. São Paulo: Pioneira, 2000. cap.17. 
STAHL, W.; SIES, H. Perspectives in biochemistry and biophysics, lycopene: a biologicaly important carotenoid for human? Archives of Biochemistry and Food Chemistry, v.43, n.3, p.579-86, 1996.

SPERS, E.E.; CHADDAD, F.R. Política de qualidade e segurança alimentar na Europa. Preços Agrícolas, v.11, n.123, p.13-15, 1997.

SPERS, E.E.; KASSOUF, A.L. A segurança dos alimentos: uma preocupação crescente. Higiene Alimentar, v.10, n.44, p.18-21, 1996a.

SPERS, E.E.; KASSOUF, A.L. A abertura de mercado e a preocupação com a segurança dos alimentos. Higiene Alimentar, v.10, n.46, p.16-26, 1996 b.

UNDERHILL, S.E.; FIGUEROA, E.E. Consumer preferences for non-conventionally grown produce. Journal of Food Distribution Research, v.27, n.2, p.56-66, July 1996.

VANEGAS, J.A.G. Fisiologia pós-colheita de tomates (Lycopersicon esculentum Mill), cultivar Ângela. Campinas, 1987. 123p. Dissertação (Mestrado) - Faculdade de Engenharia Agrícola, Universidade de Campinas.

VIGLIO, E.C.B.L. Produtos orgânicos: uma tendência para o futuro? Agroanalysis, v.16, n.12, p.8-12, 1996.

WEAVER, R.; EVANS, D.; LULOFF. A.E. Pesticide use to tomato production: consumer concerns and willingness to pay. Agribusiness, v.8, n.2, p.131-142, 1992. 
WIER, M.; ANDERSEN, L.M. Studies on consumer demand for organic foods: a survey. Copenhagen: AKF, Sept. 2001. 15p. (Project on consumer demand for organic foods: domestic and foreign market perspectives. Working Paper, 1) http://www.akf.dk/organicfoods/Papers/wp1-mw.pdf (15 May 2002)

WILBERG, V.C.; RODRIGUEZ-AMAYA, D.B. Quantificação de $\beta$-caroteno e licopeno em tomate e em alguns dos seus produtos por cromatografia líquida de alta eficiência. Ciência e Tecnologia de Alimentos, v.13, n.2, p.132-141, 1993.

ZAGO, V.C.P. Teores de nitrato em couve, Brassica Oleracea var. acephala, adubada com esterco bovino e uréia. Seropédica: EMBRAPA, CNPAB, 1996. 5p. (Comunicado Técnico, 13) 